\title{
Composing Imitative Counterpoint around a Cantus Firmus: Two Motets by Heinrich Isaac
}

JULIE E. CUMMING

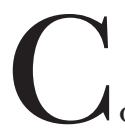

ompositions based on cantus firmus and compositions using imitative texture are often considered stylistically opposed. Cantus firmus is associated with the Middle Ages, imitative texture with the high Renaissance. In his study of Palestrina's first book of four-voice motets, Peter Schubert claims that, even in Palestrina, pieces with long-note tenors "are fundamentally different [from pieces without tenor cantus firmi] as to both compositional process and aesthetic

\begin{abstract}
Research and travel for this paper was funded by the Social Sciences and Humanities Research Council of Canada. My work on this paper was inspired by that of my colleague Peter Schubert. He also read a draft and checked my counterpoint in the added voice for Inviolata; any parallel fifths that remain are my responsibility. I would like to thank my student research assistants, Jacob Sagrans, Remi Chiu, Daniel Donnelly, and Laura Osterlund, the anonymous readers for the journal, and my husband, Lars T. Lih, who read two drafts. The paper was originally written for the conference "Heinrich Isaac and his World," Indiana University, Bloomington, 21 May 2010; I would also like to thank Giovanni Zanovello, Blake Wilson, and David Burn for organizing the conference, and the Jacobs School of Music for hosting it.
\end{abstract}

\footnotetext{
The Journal of Musicology, Vol. 28, Issue 3, pp. 231-288, ISSN 0277-9269, electronic ISSN 1533-8347. (C) 2011 by the Regents of the University of California. All rights reserved. Please direct all requests for permission to photocopy or reproduce article content through the University of California Press's Rights and Permissions website, http://www.ucpressjournals.com/reprintInfo.asp. DOI: 10.1525/ jm.2011.28.3.231.
} 
result." ${ }^{1}$ Yet in the decades around 1500 many composers combined the new style of imitative polyphony with the older practice of basing a work on a cantus firmus. In this article I show how these two techniques were combined by looking closely at the construction of two of Heinrich Isaac's cantus-firmus motets, Inviolata integra et casta es Maria and Alma redemptoris mater (for the sources of these two motets, see table 1). ${ }^{2}$

I have chosen these two motets for several reasons. Isaac's works in general have received little close analytical attention. While worthy of study, these two pieces are almost unknown, largely due to a lack of easily available modern editions. Inviolata is found only in Noblitt's edition of Munich $3154,{ }^{3}$ and Alma redemptoris mater in a hand-copied score in the appendix to a 1963 article by Martin Just. ${ }^{4}$

More important, however, is the fact that these works demonstrate three different approaches to the use of chant cantus firmi: canonic cantus firmus, long-note cantus firmus, and chant paraphrase in a single voice. In Inviolata Isaac presents the cantus firmus in canon with itself at the octave after two breves. The use of a canonic cantus firmus is a fairly

1 Peter N. Schubert, "Hidden Forms in Palestrina's First Book of Four-Voice Motets," Journal of the American Musicological Society 60 (2007): 483-556 at 489-90, n. 16. (A corrected version of the appendix to this article is found on http://www.music.mcgill.ca/ schubert.)

${ }^{2}$ For recent articles that look at cantus firmus and imitation in some other works by Isaac, see the issue on Heinrich Isaac, ed. Ulrich Tadday, Musik-Konzepte, Neue Folge 148/149 (2010): esp. Thomas Schmidt-Beste, "Stil und Struktur in den Tenormotetten Heinrich Isaacs," 65-88; Andreas Pfisterer, "Imitationstechniken bei Isaac," 89-103, and Katelijne Schiltz, “'Aus einem Hauptgedanken alles Weitere entwickeln!': Die Kanons in Isaacs Choralis Constantinus II," 120-34.

${ }^{3}$ For a modern edition, see Der Kodex des Magister Nicolaus Leopold, Staatsbibliothek München Mus. Ms. 3154, ed. Thomas L. Noblitt, Das Erbe deutscher Musik 80 (Kassel: Bärenreiter, 1987), no. 54, 257-65. In his critical report, Noblitt posits a dating of 1476 for the motet, based on the watermark for most of fascicle 7 in which the motet is found, although there is no watermark on fol. 74; see Noblitt, Der Kodex des Magister Nicolaus Leopold, part 4, Das Erbe deutscher Musik 83 (1996): 321 and 344. Joshua Rifkin also discusses the dating of this piece in "Munich, Milan, and a Marian Motet: Dating Josquin's 'Ave Maria ... virgo serena'," Journal of the American Musicological Society 56 (2003): 239-350, at 296 (fig. 5 , which is a facsimile of fol. $74^{\mathrm{v}}$ ), 300, 301, n. 124, 304-5, 305, n. 133, 313, n. 156. He places it in the mid-1480s and seems to agree with Reinhard Strohm in associating it (along with two other pieces by Isaac in the same fascicle, Argentum et aurum and Ecce sacerdos magnus) with Isaac's stay at Innsbruck in 1484. See Reinhard Strohm, "Heinrich Isaac und die Musik in Deutschland vor 1492," in Heinrich Isaac und Paul Hofheimer im Umfeld von Kaiser Maximilian I, ed. Walter Salmen (Innsbruck: Edition Helbling, 1997), 21-41 at 29 and 33, n. 42. For a discussion of the other source, Motetti a cinque, see Stanley Boorman, Ottaviano Petrucci: A Catalogue Raisonné (New York: Oxford University Press, 2006), no. 46, 696-701.

4 Martin Just, "Heinrich Isaacs Motetten in italienischen Quellen," Analecta musicologica 1 (1963): 1-19; the handwritten score is included on seven unnumbered pages between 16 and 17, and there is a useful discussion of the piece on pp. 15-17. Just suggests that the piece was composed while Isaac worked in Florence, between 1484 and 1494-96 (p. 4); he also suggests that it was "a kind of audition piece for Maximilian" (15). On Motetti C, the earliest source for the motet, see Boorman, Catalogue, no. 15, 549-64, and 557 and 887 on the attribution to Isaac in the copy found in Wolfenbüttel, Herzog August Bibliothek. I consulted a microfilm of the copy in Munich, Bayerische Staatsbibliothek. 
TABLE 1

Sources for Isaac's Inviolata integra et casta es Maria and Alma redemptoris mater

\section{Inviolata integra et casta es Maria (missing contratenor 2; chant cantus firmus in canon)}

RISM 1508 ${ }^{1}$, Motteti a cinque Libro primo. Venice: Ottaviano Petrucci [28 November 1508], no. VII, fols. 16 $-17^{\mathrm{r}}$ (Superius), 24v (Tenor), $25^{\mathrm{r}}$ (Bassus), and $45^{\mathrm{v}}$ (Contratenor primus), Isaac. Contratenor secundus is lost.

Munich, Bayerische Staatsbibliothek, Mus. Ms. 3154, fol. 74v Isaac. Only the superius and the low tenor cantus firmus (called contratenor primus by Petrucci) survive.

\section{Alma redemptoris mater (chant paraphrased in the tenor)}

RISM 1504르, Motetti C. Venice: Ottaviano Petrucci, 15 September 1504, no. 18 , fols. $7^{\mathrm{r}}-7^{\mathrm{v}}$ (Superius), $17^{\mathrm{r}}-18^{\mathrm{r}}$ (Altus), $14^{\mathrm{v}}$ (Tenor), and $15^{\mathrm{r}}-15^{\mathrm{v}}$ (Bassus), Anon. (with handwritten attribution in one copy of the print).

Florence, Biblioteca Nazionale Centrale, MS II.I.232 (olim Magliabecchi XIX.58), no. $37,113^{\mathrm{v}}-117^{\mathrm{r}}$, IZACH.

Dresden, Sächsische Landesbibliothek, MS Mus. 1/D/505 (olim Annaberg 1248), 466-469, Anon.

Rome, Vatican City, Biblioteca Apostolica Vaticana, MSS Palatini Latini 1976-79, no. 32, 92r $-96^{\mathrm{r}}$, Anon.

common way to combine cantus firmus and imitation, especially in fiveand six-voice motets and chansons from after 1500; this motet may be one of the first examples of the technique. ${ }^{5}$ Analyzing the structure of Inviolata, which is missing a voice, actually allows us to reconstruct that missing voice with a great deal of confidence. In Alma redemptoris mater the chant cantus firmus appears in the tenor throughout. ${ }^{6}$ The tenor alternates between paraphrase and long-note treatment of the chant and passages of

5 Canonic cantus firmi became standard in Josquin's later five- and six-voice motets and chansons; see John Milsom, "Motets for Five or More Voices," 281-320, esp. 284-85, 288-89, 300, and Lawrence Bernstein, "Chansons for Five and Six Voices," 393-422, in The Josquin Companion, ed. Richard Sherr (New York: Oxford University Press, 2000). I know of four other pieces in Petrucci's Venetian motet prints in which two voices are in canon throughout: Compère, Quis numerare queat (Motetti A, no. 29; the result is a five-voice piece), Josquin, Homo quidam (Motetti a cinque, no. 5), and two four-voice motets in Motetti libro quarto, Basiron, Inviolata integra et casta (no. 29), and an anonymous Regina celi (no. 42) (the canon, between altus and tenor in both cases, is resolved in the two partbooks).

6 In my book The Motet in the Age of Du Fay (Cambridge: Cambridge University Press, 1999), 266-70, I called the kind of motet in which the chant remains in a single voice throughout and all voices have the text of the chant cantus firmus a "chant-paraphrase motet." Whereas mid-fifteenth-century chant-paraphrase motets normally put the chant in the top voice, later in the century it becomes more and more common to put the chant in the tenor voice, after the fashion of the tenor motet (see Cumming, The Motet in the Age of Du Fay, 270-78). It is also common in chant-paraphrase motets to have imitation between 
rest. This piece therefore allows us to learn about how Isaac composed imitative polyphony around both types of tenor treatment. These two motets provide a fairly comprehensive guide to cantus-firmus setting and compositional process as practiced by Isaac and his contemporaries.

Jessie Ann Owens's study of Isaac's autograph of his polyphonic setting of a sequence for St. Catherine, Sanctissimae virginis votiva festa, has served as an inspiration for my research. Both Inviolata and the sequence for St. Catherine are in paired-versicle form with repeating melodies (though Sanctissimae is an alternatim setting, with the odd strophes in chant and the even strophes in polyphony). In both Sanctissimae and Alma redemptoris mater the chant is found in a single voice throughout (though Sanctissimae does not use long-note cantus firmus). Owens used evidence from the autograph to prove that Isaac composed "one section of the piece at a time . . phrase by phrase, point by point." " My analyses show that Isaac probably used the same approach in Inviolata and Alma redemptoris mater.

In her study of Rore's compositional process in the Milan Partbooks, Owens introduced the term "module" for a contrapuntal combination that is repeated. Peter Schubert explored the use of modules in the music of Palestrina, developing a rich analytical terminology for imitative technique. ${ }^{8}$ 234 In this article I extend Schubert's approach to an earlier repertoire, showing that modular structure and imitative texture are central to Isaac's compositional process in these two motets and that, unlike Palestrina, Isaac used modules extensively even in passages composed around a long-note tenor. In addition to modules, I also identify approaches to composition derived from techniques of improvised polyphony such as parallel imperfect intervals and improvisable imitation (or stretto fuga).$^{9}$ Although my focus is on Isaac's Inviolata and Alma redemptoris mater, the compositional techniques described here appear also in countless works by Isaac's contemporaries,

the superius and tenor, as we see in Alma redemptoris mater at the beginnings of both partes. This usage of "chant paraphrase" is different from the "chant-paraphrase Mass," such as Josquin's Missa Pange lingua, in which each phrase of the chant is used as the soggetto for a point of imitation, but the chant is not found complete in any one voice. Because of this possible confusion, I would now call this kind of motet a "chant cantus-firmus motet" (in contrast to the tenor motet, in which the text of the cantus firmus is different from that of the other voices).

7 Jessie Ann Owens, Composers at Work: The Craft of Musical Composition 1450-1600 (New York: Oxford University Press, 1997), chap. 10, "Henricus Isaac," 258-90, at 268. The setting is found in an autograph that is bound into Berlin 40021, created sometime before 1498 .

8 The term comes from Jessie Ann Owens, "The Milan Partbooks: Evidence of Cipriano de Rore's Compositional Process," Journal of the American Musicological Society 37 (1984): 284; see also her Composers at Work, 251. The concept of the module was developed fully by Schubert in "Hidden Forms."

9 These are described in Peter Schubert, Modal Counterpoint, Renaissance Style (2nd ed. New York: Oxford University Press, 2008). See also notes 31-32, 34, and 37-38. 
and the diagrams and terminology I have developed for the analysis of these two compositions by Isaac can be applied to other works and other genres.

\section{Inviolata integra et casta es Maria}

Unfortunately the contratenor 2 partbook of Petrucci's Motetti a cinque (1508), a source for Isaac's Inviolata, has not survived. For most of the motets in the collection, the missing voice can be supplied from a concordant source. But by some evil chance, the voice is also missing from the concordant source for Inviolata (Munich 3154, see table 1). This works to our advantage, however, since reconstructing the missing voice provides a composer's-eye view of the process of composing around a cantus firmus. ${ }^{10}$ To reconstruct the missing fifth voice, we must first understand the structure of the piece on the basis of the surviving voices.

The cantus firmus of Inviolata is a very light paraphrase of the sequence Inviolata. ${ }^{11}$ The chant cantus firmus is in canon between the voices that Petrucci labeled Contratenor 1 (dux) and Tenor (comes) (see complete score in appendix I).$^{12}$ The $d u x$, which enters in measure 7 , is the lowest voice in the score; because it contains the cantus firmus, I consider it the tenor and label it T (Ct 1). The comes, which enters after two measures at the octave above, is the middle voice; I label it T (+8) (ex. 1). The sequence Inviolata uses the standard paired-versicle structure. In Isaac's setting its melody is segmented, with rests (usually for two measures) between each phrase. I have labeled each segment with a capital letter in order to make clear the paired-versicle structure and melodic identity. If the tune is repeated, it gets the same letter; if it is varied, it gets a prime mark, as in $\mathrm{A}^{\prime}$ and $\mathrm{B}^{\prime}$ on the second line of example 1. I indicate the tune's return later as part of

10 For another study and reconstruction of a motet from Motetti a cinque, see Theodor Dumitrescu, "Reconstructing and Repositioning Regis's Ave Maria . . virgo serena," Early Music 37 (2009): 73-88.

11 The same chant is used in three other pieces in Petrucci's Venetian motet prints. There is an anonymous setting in Motetti $C$ (no. 35) that divides the piece into twelve sections corresponding to the twelve phrases of the chant, with a long-note cantus firmus moving from voice to voice. There are two settings in Motetti libro quarto: no. 18, by Ghiselin, and no. 29, by Basiron. Ghiselin puts the chant in the superius and combines it with Binchois's Comme femme in the tenor. Basiron puts the chant in canon at the unison in the altus and tenor. All three use very light paraphrase of the chant for most of the piece, and all three use almost identical versions of the chant, very similar to the version found in the Liber usualis (Tournai: Desclée Company, 1961), 1861-62. In the Liber, as in Isaac's motet, the chant is on F. In the other three Petrucci settings, the chant appears on C. Isaac is quite faithful to the chant for most of the piece, although the phrases of text do not correspond to the phrases of music the way they do in the Liber and in the other Petrucci motets in the sections of the chant I have labeled $\mathrm{F}$ and $\mathrm{H}$ in ex. 1. Isaac is also quite free with the chant in the final section labeled "I"; in this final section he also leaves out some of the text in the canonic tenor voices, while keeping it in the other voices.

12 In Appendix I the motet is transcribed from Motetti a cinque with note values halved. 
EXAMPLE 1. Tenor voice of Inviolata (beginning at its entrance in m. 9), with sections labeled
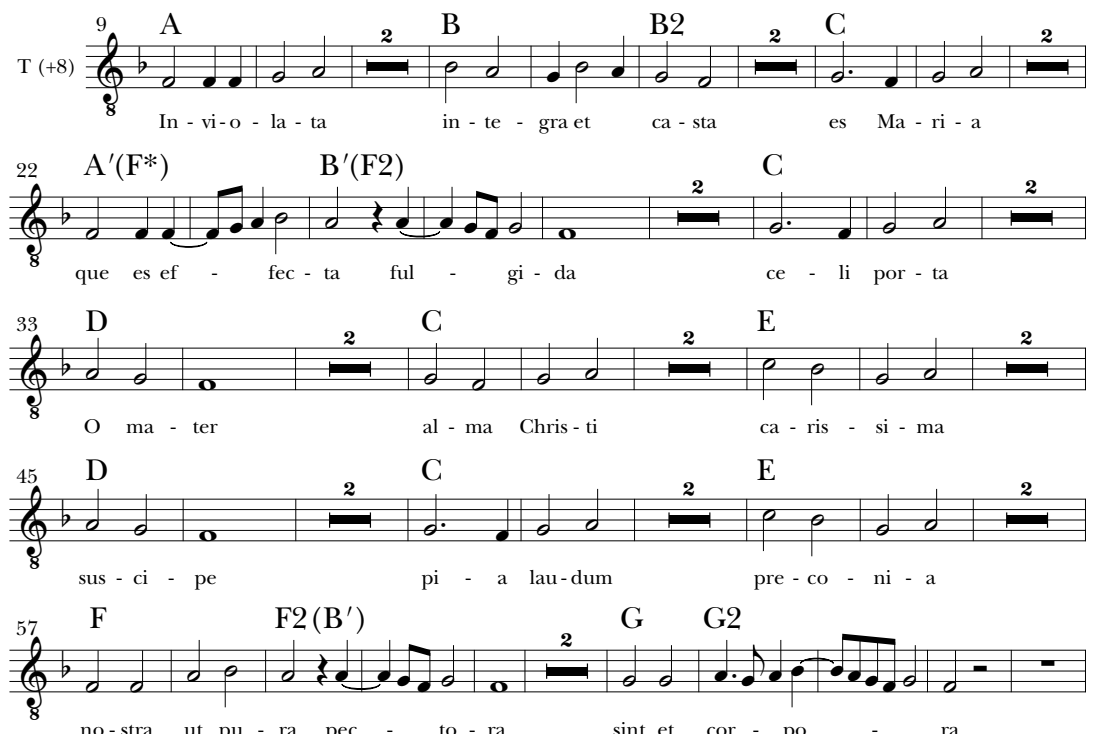

sint et cor - po

F3

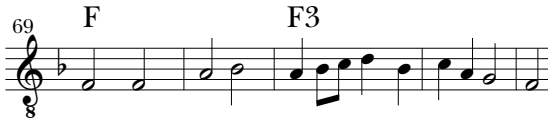

que nunc fla-gi - tent___cor-da et o - ra

F4

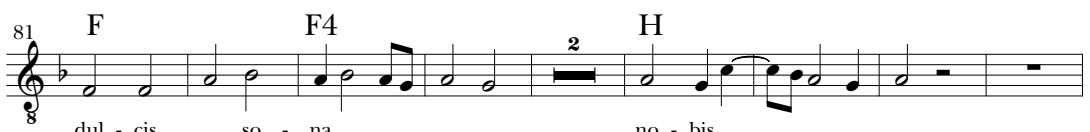

F5

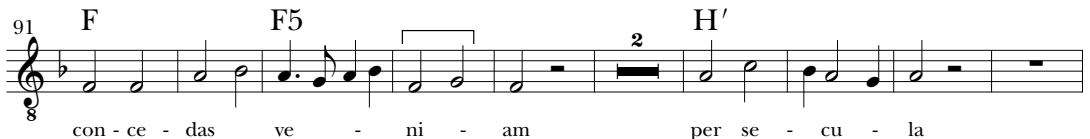

$102 \mathrm{I} \quad \mathrm{I} 2$
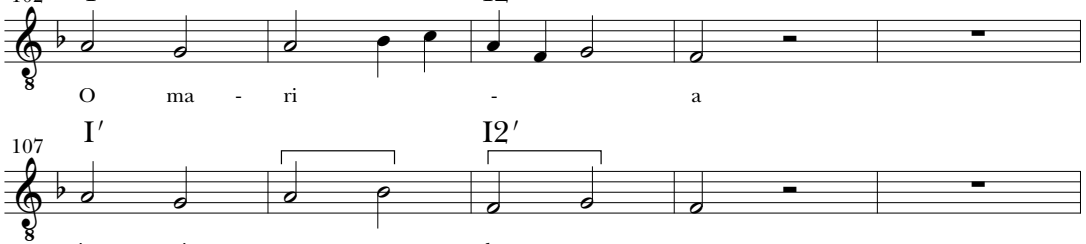

in - vi - 0

la

ta

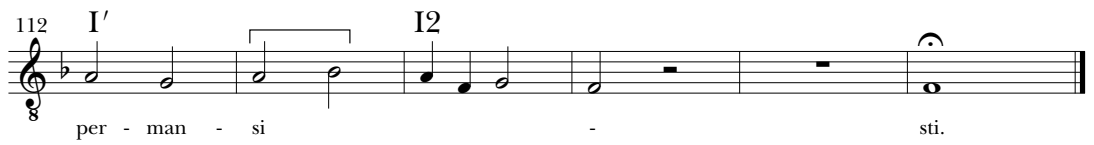


another paired versicle with a letter in parentheses, as in $\mathrm{B}^{\prime}(\mathrm{F} 2)$. $\mathrm{A}^{\prime}$ is a varied version of $A$ that is very similar to $\mathrm{F}$; I indicate that with $\mathrm{A}^{\prime}\left(\mathrm{F}^{*}\right) .{ }^{13}$

The two-measure time interval of imitation between the canonic tenor voices means that most of the piece divides into pairs of two-measure segments with the same cantus-firmus phrase in each member of a pair. ${ }^{14}$ These segments are separated in the score in appendix I with bar lines through the staff and are indicated by separate columns in the diagram of the piece in appendix II. When phrases of the cantus firmus are two measures long (this is the case at the beginning), the canonic voices have no overlap. In cases when phrases are longer than two measures (for example B), I provide a number after the letter to show the continuation (e.g., B2). These longer phrases result in overlapping canonic cantus-firmus voices (B in the comes overlaps with B2 in the $d u x$; ex. 7, below, or $\mathrm{m} .13$ in appendix I). In the second half of the piece most of the phrases are longer than two measures, so there is more overlapping. The F phrase has four different continuations (marked as F2, F3, F4, F5).

The canonic cantus firmus forms a rudimentary imitative framework for the piece. But that is not all-the other voices also repeat musical material in two-measure segments over the repetitions of the cantus firmus (mm. 5561 in ex. 2). I have labeled the repeating non-cantus-firmus melodies with lowercase letters (the tunes with lowercase letters have no musical relationship to the cantus-firmus phrases labeled with capital letters). This structure is represented in table 2 (see also appendix II for a diagram of the whole piece). The repeated contrapuntal combination of melodies, such as the combination of $\mathrm{s}$ and $\mathrm{F}$ in measures 55-56 and 57-58, and the combination of F2 and $t$ in measures 57-58 and 59-60, constitutes a module. In table 2 I used different shades of gray to distinguish these pairs.

The whole motet is constructed as a series of two-, three-, and four-voice modules comprising cantus-firmus melodies and repeated melodies in the other voices. This modular structure is the key to reconstructing the missing voice: find a place where one voice in the module is missing and supply that melody in contratenor 2 . When we see a threevoice vertical combination of melodies in one column (such as $\mathrm{s} / \mathrm{F} / \mathrm{t}$ in column 2, table $3 \mathrm{a}$, and mm. 57-58 in ex. 3) and two of those voices in another column (s/F in column 1, table $3 \mathrm{a}$, and $\mathrm{mm} .55-56$ in ex. 3), we can add the third melody to contratenor 2 to complete a three-voice module (shaded in light gray in table $3 \mathrm{a}$ ). We can even add a phrase

13 See below, note 43 .

14 In my labeling all but one of the phrases begin with a two-measure unit followed by rests or by a two- or three-measure continuation (three-measure continuations are labeled as two-plus-one measures, because of the two-measure time interval of the canon). Only with the $\mathrm{G}$ phrases did I alter this pattern, to reflect the fact that in this verse, variation of the melody begins with the second measure; I therefore made G one measure, and G2 and G3 three measures. 
EXAMPLE 2. Inviolata, mm. 55-61
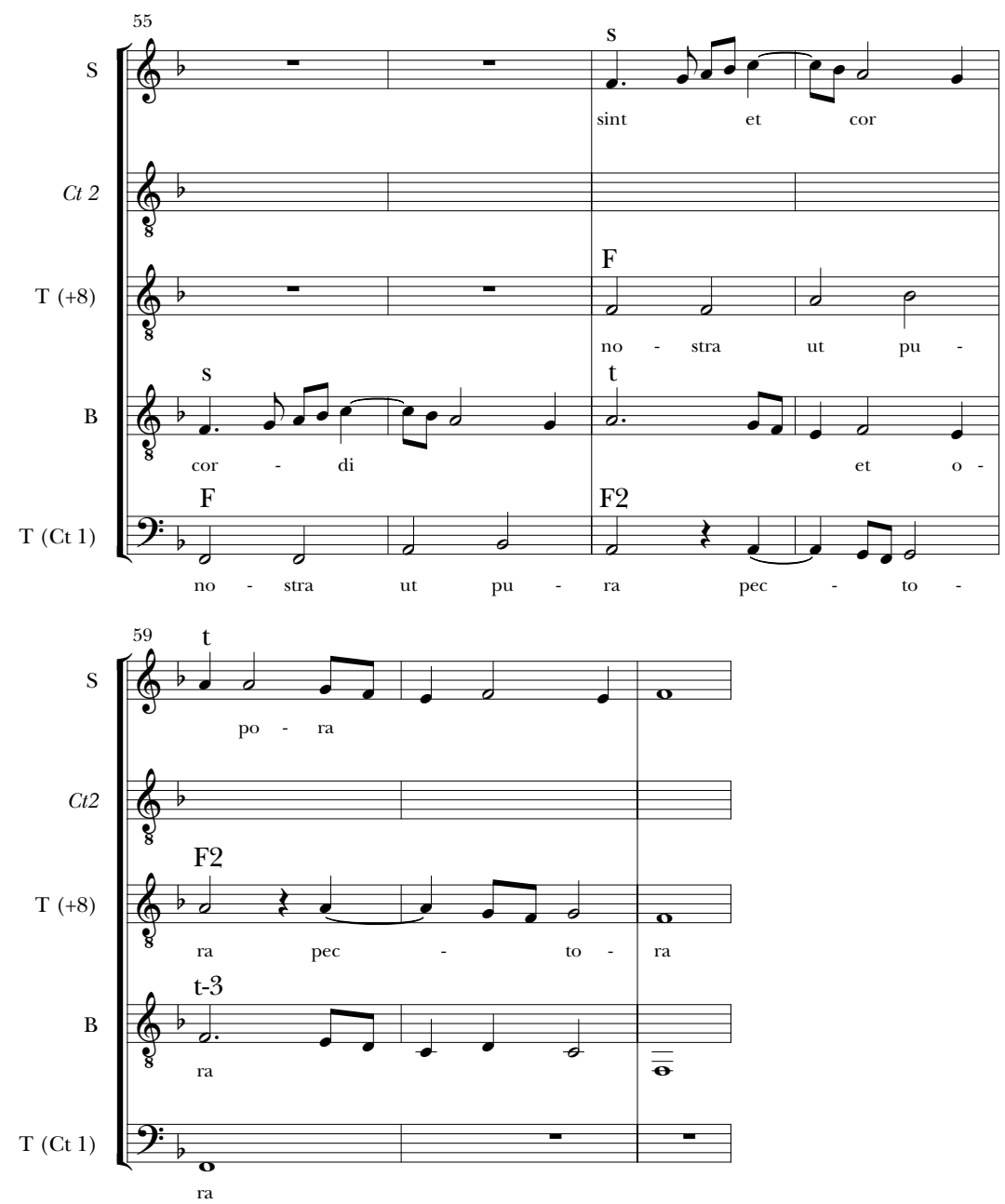

derived from the cantus firmus, "F," in measures 59-60 (the third column of table $3 \mathrm{~b}$ ) to complete another three-voice module. (Because the "F" phrase has to be slightly modified to avoid dissonance with the $\mathrm{C}$ in $\mathrm{t}^{\prime}-3$, I label the added voice $F^{\prime}$.) This allows the module F/t/F2 (shaded in dark gray in the second column of table $3 \mathrm{~b}$ ) to be repeated in the third column as $\mathrm{t} / \mathrm{F}^{\prime} / \mathrm{F} 2$ (with $\mathrm{t}$ and $\mathrm{F} 2$ transposed up an octave).

Repetition of musical phrases at the unison or at the octave (resulting in invertible counterpoint at the octave, ic8, mm. 55-61 in ex. 3 ) is characteristic of most of the repeated modules in the piece. Some 
TABLE 2

Inviolata, diagram of $\mathrm{mm} .55-61$

\begin{tabular}{lcccc}
\hline Mm. & $55-56$ & $\begin{array}{c}57-58 \\
\text { Text }\end{array}$ & \multicolumn{3}{c}{$59-60$} & 61 \\
$\mathrm{~S}$ & & $\mathrm{~s}$ & $\mathrm{t}$ & $>$ \\
\cline { 2 - 5 }$[$ Ct 2] & & $\mathbf{F}$ & $\mathbf{F 2}$ & $>$ \\
$\mathrm{T}(+8)$ & & $\mathrm{t}$ & $\mathrm{t}^{\prime}-3$ & $>$ \\
$\mathrm{B}$ & $\mathrm{s}$ & $\mathbf{F 2}$ & $>$ & \\
$\mathrm{T}(\mathrm{Ct} 1)$ & F & & \\
\hline
\end{tabular}

" $\mathrm{t}$ ' -3 " means that a varied version of tune $\mathrm{t}(\mathrm{t})$ is transposed down a third

">" means the melody continues into the next mea-

sure by one note

modules, however, involve invertible counterpoint at the twelfth (ic12). In the second column of table $4 \mathrm{a}$ ( $\mathrm{mm} .81-82)$ the two-voice combination F over F4 (shown in contrasting shades of gray) results from the canonic structure of the cantus firmus, which indicates that these two voices must have been composed first. This combination also works if inverted at the twelfth; the inverted combination appears in the first column $(\mathrm{F} 4+5$ over $\mathrm{F}$ in $\mathrm{mm}$. 79-80 in ex. 4). As it appears in example 4, $\mathrm{F}$ in the first column of table $4 \mathrm{a}$ is an octave lower than in the second column, while F $4+5$ in the first column of table $4 \mathrm{a}$ is a fifth higher than F4 in the second column; the first column therefore derives from the second column through invertible counterpoint at the twelfth (ic12). ${ }^{15}$ The second and third columns are also related through ic12, although here three voices are involved (see table $4 \mathrm{~b}$ and ex. 4). The tunes F4 and w (shown in light gray) are an octave higher in the third column than they are in the second column, while $\mathrm{F} 4+10$ (dark gray) is transposed down a twelfth, becoming F4+6. ${ }^{16}$

To construct the missing voice, we can add $F 4+10$ to the first column by analogy with the superius in the second module ( $\mathrm{mm}$. $81-82$ in ex. 5 and table 5). This results in a triple ic12 combination (in relation to the second column), similar to the triple ic12 combination in the second and third columns. Since the texture is already quite thick, there is no need to add anything to the second column. ${ }^{17}$

15 On ic12, see Schubert, Modal Counterpoint, Renaissance Style, 177-85.

16 On ic12 where three voices are involved (a kind of triple counterpoint), see ibid. 237-42. F4+6 abandons the strict transposition in $\mathrm{m}$. 84, where it provides a free bassus voice for the cadence.

17 There is some regrettably awkward counterpoint in mm. 81-82: the leap from D to $\mathrm{G}$ in the bassus against the $\mathrm{F}$ in the tenor would not normally be permitted, even in Isaac's time. We must presume that Isaac did it because he wanted to repeat the cadential module w/F4, heard without the cantus-firmus tune $\mathrm{F}$ in the third column (mm. 83-84). To avoid a similar awkwardness, I have put free material in the contratenor 2 part in $\mathrm{m}$. 83 and used the end of $\mathrm{F}$ in $\mathrm{m} .84$ in ex. 5 . 
EXAMPLE 3. Inviolata, mm. 55-61 with Ct 2
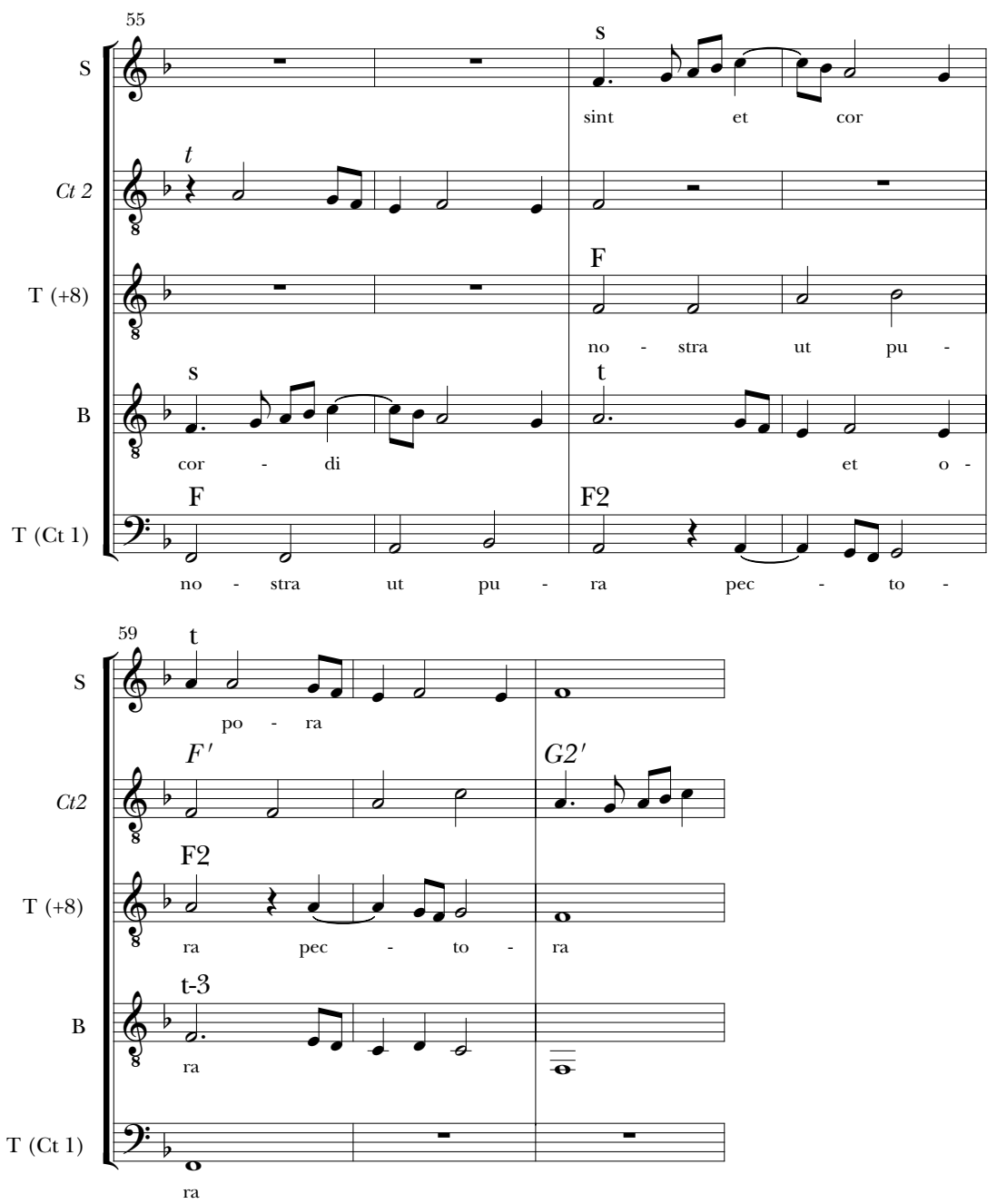

Modules are also the key to reconstructing the beginning of the motet, where there is a traditional point of imitation with Vorimitation of the cantus-firmus melody, which enters in measure 7 (ex. 6 and table 6). The bassus begins the piece with the cantus-firmus tune A. The superius comes in with the same tune four measures later and two octaves higher than the bassus. Clearly the missing contratenor 2 needs to enter with tune $\mathrm{A}$ in measure 3, an octave higher than the bassus (mm. 3-4 in ex. 7 and table 7 ). This creates a two-voice combination with the bassus, tune 
TABLE 3

Inviolata, diagram of mm. 55-61 with Ct 2; modules are shaded

\begin{tabular}{|c|c|c|c|c|c|c|c|c|}
\hline \multicolumn{5}{|c|}{$\begin{array}{l}\text { 3a. Three-voice module in } \\
\text { columns } 1 \text { and } 2\end{array}$} & \multicolumn{4}{|c|}{$\begin{array}{l}\text { 3b. Three-voice module in } \\
\text { columns } 2 \text { and } 3\end{array}$} \\
\hline Mm. & $55-56$ & $57-58$ & $59-60$ & 61 & $55-56$ & $57-58$ & $59-60$ & 61 \\
\hline Text & \multicolumn{4}{|c|}{ Nostra ut pura pectora } & \multicolumn{4}{|c|}{ Nostra ut pura pectora } \\
\hline $\mathrm{S}$ & & s & $\mathrm{t}$ & $>$ & & $\mathrm{s}$ & $\mathrm{t}$ & $>$ \\
\hline [Ct 2] & $t$ & $>$ & $F^{\prime}$ & $G 2^{\prime}$ & $t$ & $>$ & $F^{\prime}$ & $G 2^{\prime}$ \\
\hline $\mathrm{T}(+8)$ & & $\mathbf{F}$ & $\mathbf{F} 2$ & $>$ & & $\mathbf{F}$ & F2 & $>$ \\
\hline B & $\mathrm{s}$ & $\mathrm{t}$ & $t^{\prime}-3$ & $>$ & $\mathrm{S}$ & $\mathrm{t}$ & $\mathrm{t}^{\prime}-3$ & $>$ \\
\hline $\mathrm{T}(\mathrm{Ct} 1)$ & $\mathbf{F}$ & F2 & $>$ & & $\mathbf{F}$ & F2 & $>$ & \\
\hline
\end{tabular}

Italics are used for the labels for the reconstructed $C t 2$

A (contratenor 2) over the non-cantus-firmus melody b (bassus) (table 7). The missing contratenor 2 can continue to imitate the bassus with melody $\mathrm{b}$ in measures $5-6$, so that the combination $\mathrm{A}$ over $\mathrm{b}$ in measures $2-3$ is repeated in measures 5-6 with melody A in the superius over melody $\mathrm{b}$ in contratenor 2 . Contratenor 2 is also needed to provide the "modus tenoris," or tenor function, from the second to the first degree at the cadence to $\mathrm{C}$ in measure $8 .{ }^{18}$ In measures $9-10$ we find melodies $\mathrm{A}$ and $\mathrm{c}$ in the tenor and the bassus; once we add melody $\mathrm{b}$ in contratenor 2 , we repeat the three-voice module already heard in measures 5-6. The only place we need to write free material for this passage in the missing voice is in measure 7 (marked as @ in ex. 7 and table 7 ).

Example 7 and table 7 show that even a traditional point of imitation can be based on modular construction. Once we add contratenor 2, tunes $\mathrm{A}, \mathrm{b}$, and c, first presented horizontally in the bassus, are combined vertically in the third column (mm. 5-6). Isaac first had to write the vertical

18 The term "modus tenoris" comes from Guilielmus Monachus. In his The Modes of Classical Vocal Polyphony, Bernhard Meier assigned the terms "clausula cantizans," "clausula tenorizans," "clausula basizans," and "clausula altizans" to the voices according to their function at the cadence (The Modes of Classical Vocal Polyphony, trans. Ellen S. Beebe [rev. ed. New York: Broude Brothers, 1988], 90-101). He does not identify the origin of his terms. According to Eggebrecht's Handwörterbuch, these terms first appear only in the eighteenth century, in the treatise of Johann Walter (1732) (see Siegfried Schmalzriedt, with Elke Mahlert and Bernd Sunten, "Kadenz," in Handwörterbuch der musikalischen Terminologie, ed. Hans Heinrich Eggebrecht [Wiesbaden: F. Steiner, 1974], 8). Guilielmus Monachus created perfectly good terms for the same voice functions ca. 1480: modus suprani, modus tenoris, and modus contrae (i.e., contratenor bassus). I advocate using Monachus's terms, at least for music ca. 1500. See Guilielmus Monachus, De preceptis artis musicae, ed. Albert Seay (American Institute of Musicology, 1965), 41-42; ed. and trans. in Eulmee Park, “'De preceptis artis musicae' of Guilielmus Monachus: A New Edition, Translation, and Commentary" (PhD diss., Ohio State University, 1993), sentences 53-63; 69-71 (Latin); 188-91 (English). 
EXAMPLE 4. Inviolata, mm. 79-84

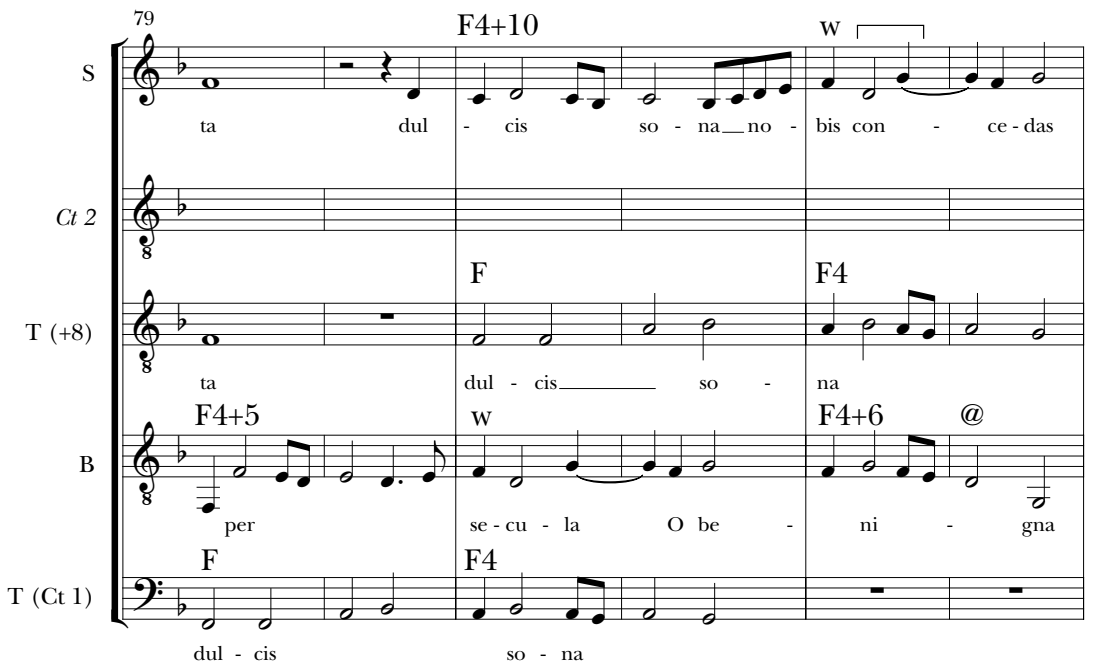

TABLE 4

Inviolata, diagram of $\mathrm{mm}$. 79-84, showing invertible counterpoint

4a. ic12 in columns

1 and 2

\begin{tabular}{|c|c|c|c|c|c|c|}
\hline \multicolumn{4}{|c|}{1 and 2} & \multicolumn{3}{|c|}{2 and 3} \\
\hline $\mathrm{Mm}$. & $79-80$ & $81-82$ & $83-84$ & $79-80$ & $81-82$ & $83-84$ \\
\hline Text & \multicolumn{3}{|c|}{ dulcis sona } & \multicolumn{3}{|c|}{ dulcis sona } \\
\hline S & $>$ & $\mathrm{F} 4+10$ & $\mathrm{w}$ & $>$ & $\mathrm{F} 4+10$ & $\mathrm{w}$ \\
\hline \multicolumn{7}{|l|}{ [Ct 2] } \\
\hline $\mathrm{T}(+8)$ & $>$ & $\mathbf{F}$ & F4 & $>$ & $\mathbf{F}$ & F4 \\
\hline B & $\mathrm{F} 4+5$ & $\mathrm{w}$ & $\mathrm{F} 4+6$ & $\mathrm{~F} 4+5$ & w & $\mathrm{F} 4+6$ \\
\hline $\mathrm{T}(\mathrm{Ct}$ 1) & $\mathbf{F}$ & F4 & & $\mathbf{F}$ & F4 & \\
\hline \multirow{3}{*}{$\begin{array}{l}\text { ic: Invertible } \\
\text { counterpoint }\end{array}$} & $\mathrm{F} 4+5$ & $\mathrm{~F}$ & & & $\mathrm{~F} 4+10$ & w \& F4 \\
\hline & $\mathrm{F}$ & $\mathrm{F} 4$ & & & w \& F4 & $\mathrm{F} 4+6$ \\
\hline & ic12 & & & & & ic12 \\
\hline
\end{tabular}

4b. Triple ic12 in columns combination (mm. 5-6) and then spread it out in measures 1-6 in the bassus; he could also use the vertical arrangement again in measures 9-10 (with A transposed down an octave). ${ }^{19}$ Peter Schubert has labeled this

${ }^{19}$ In $\mathrm{mm} .7-8$ tune $\mathrm{c}$ is transposed up a fifth in the bassus, resulting in ic12 between the two-voice module $\mathrm{A} / \mathrm{c}$ in $\mathrm{mm} .5-6$, and $\mathrm{c}+5 / \mathrm{A}$ in $\mathrm{mm}$. 7-8 (with tune $\mathrm{A}$ in the T/Ct 1 down two octaves). 
EXAMPLE 5. Inviolata, mm. 79-84 with Ct 2

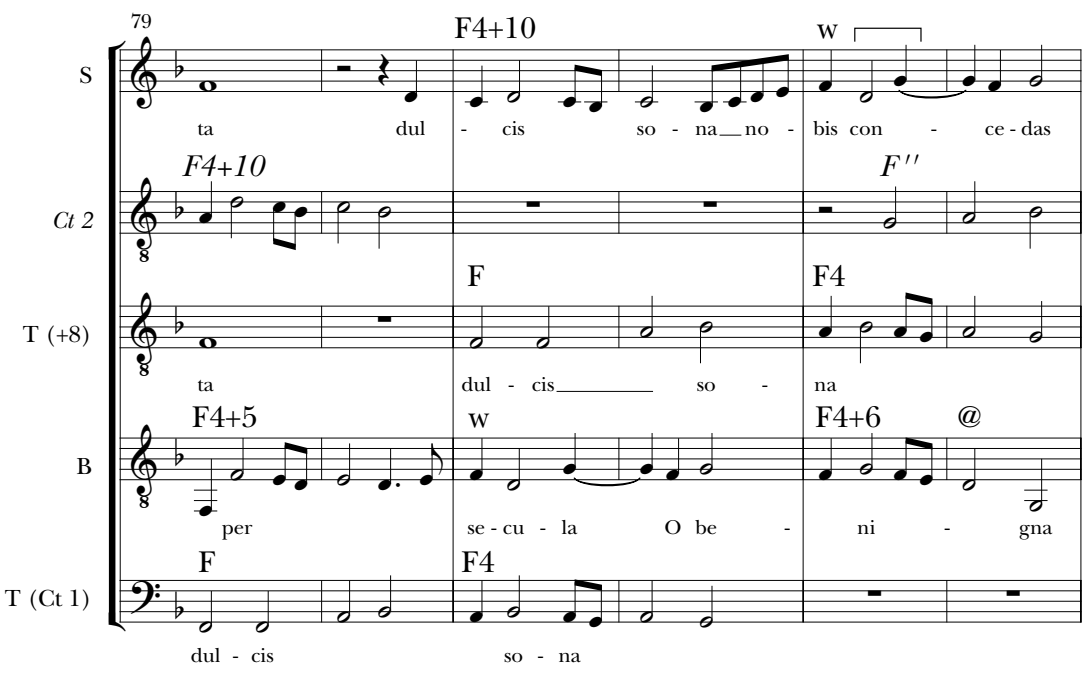

TABLE 5

Inviolata, diagram of mm. 79-84 with Ct 2

\begin{tabular}{llll}
\hline Mm. & $79-80$ & 81-82 & 83-84 \\
\hline Text & \multicolumn{3}{c}{ dulcis sona } \\
\cline { 2 - 4 } $\mathrm{S}$ & $>$ & F4+10 & w \\
{$[C t$ 2] } & F4+10 & & $F^{\prime \prime}$ \\
$\mathrm{T}(+8)$ & $>$ & F & F4 \\
$\mathrm{B}$ & $\mathrm{F} 4+5$ & $\mathrm{w}$ & $\mathrm{F} 4+6$ \\
$\mathrm{~T}(\mathrm{Ct}$ 1) & $\mathbf{F}$ & $\mathbf{F 4}$ & \\
\hline
\end{tabular}

imitative presentation type a set of Periodic Entries (or PEn), in which each voice enters after the same time interval of imitation. ${ }^{20}$

Appendix I shows the complete score of the motet including my reconstructed contratenor 2, with markings indicating repeated melodies; a diagram of the whole piece is added in appendix II. I was able to

20 See Schubert, "Hidden Forms," 488, figure 1c, and 498-504. Whereas the beginning of Inviolata presents a traditional point of imitation, most of the piece does not. Although the cantus-firmus voices are imitative, the other voices usually do not repeat the cantus-firmus material, but instead repeat motives found in other non-cantus-firmus voices, not necessarily in the same order. In "Hidden Forms," 511-13, Schubert calls this kind of structure "modules presented in a semi-imitative context" or SIm, for a "Semi-Imitative" module. 
EXAMPLE 6. Inviolata, mm. 1-15
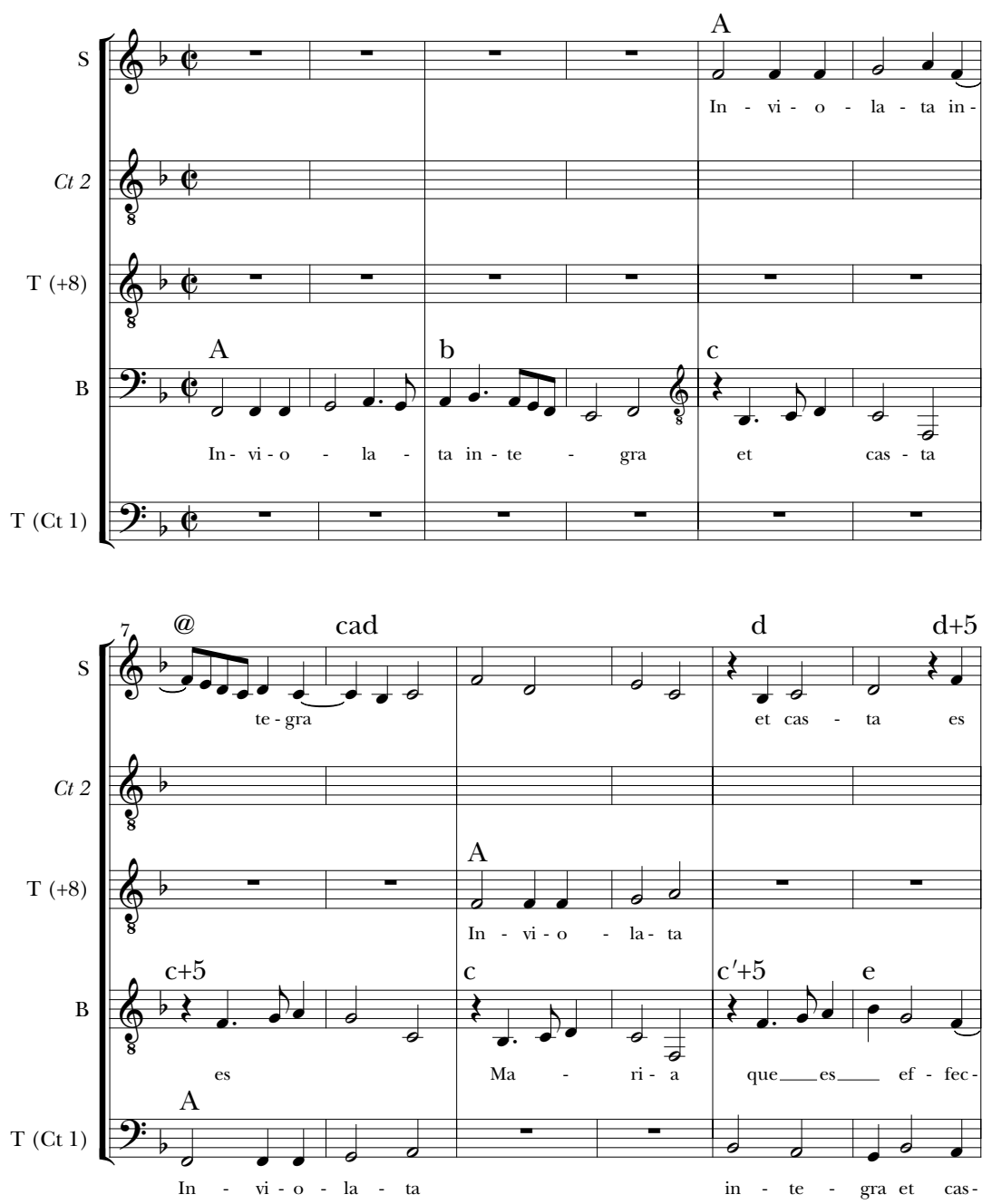

reconstruct the music of contratenor 2 largely by looking for opportunities for modular construction, and by adding a melody heard elsewhere in another voice of the motet. I also used contratenor 2 to provide missing cadential voices (marked cad in appendix II, mm. 8, 17-18, 27-28, 72, and 76), to repeat smaller motives (mm. 30-34, 50-52, and 53-54), or to supply missing notes in a triad (mm. 44, 45, 53, 54, 74, and 115-17). For some passages, for which none of these techniques worked, I added free material (shown as @ in the appendixes). 
EXAMPLE 6. (continued)

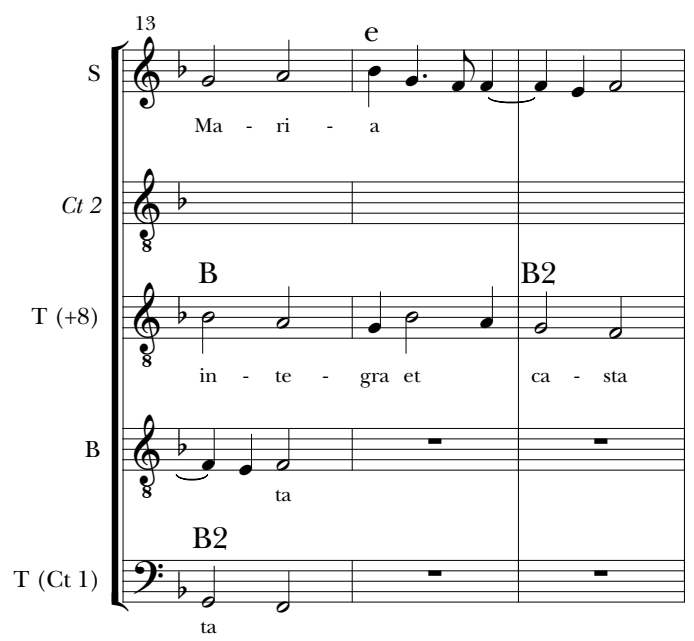

TABLE 6

Inviolata, diagram of mm. 1-15

\begin{tabular}{|c|c|c|c|c|c|c|c|c|}
\hline $\begin{array}{l}\text { Mm. } \\
\text { Text }\end{array}$ & \multicolumn{5}{|c|}{ Inviolata } & \multicolumn{3}{|c|}{ integra et casta } \\
\hline $\begin{array}{l}\mathrm{S} \\
{[\mathrm{Ct} \text { 2] }}\end{array}$ & & & A & (a) & $@$ & $\mathrm{~d}$ & $d+5 e$ & $>$ \\
\hline $\mathrm{T}(+8)$ & & & & & $\mathbf{A}$ & & B & B2 \\
\hline $\begin{array}{l}\mathrm{B} \\
\mathrm{T}(\mathrm{Ct} 1)\end{array}$ & A & $\mathrm{b}$ & c & $\begin{array}{l}\mathrm{c}+5 \\
\mathrm{~A}\end{array}$ & $\mathrm{c}$ & $\begin{array}{l}c^{\prime}+5 \text { e } \\
\text { B }\end{array}$ & $\begin{array}{l}> \\
\text { B2 }\end{array}$ & \\
\hline
\end{tabular}

@ indicates free material that is not repeated.

The strict structure of the canonic cantus firmus admittedly makes Inviolata an example of extreme regularity in modular construction. The two-measure vertical modules are the building blocks for the entire piece, and there is very little free material in any of the voices. The clarity of the structure provides a perfect primer for modular composition, one that allows us to understand the technique and recognize it in other music of the period. Isaac divided the chant into small segments, created a contrapuntal combination above or around the chant, and repeated the combination, turning it into a module. He varied the module with invertible counterpoint and additional motives, and at the beginning of the piece spread out the different 
EXAMPLE 7. Inviolata, mm. 1-15 with Ct 2
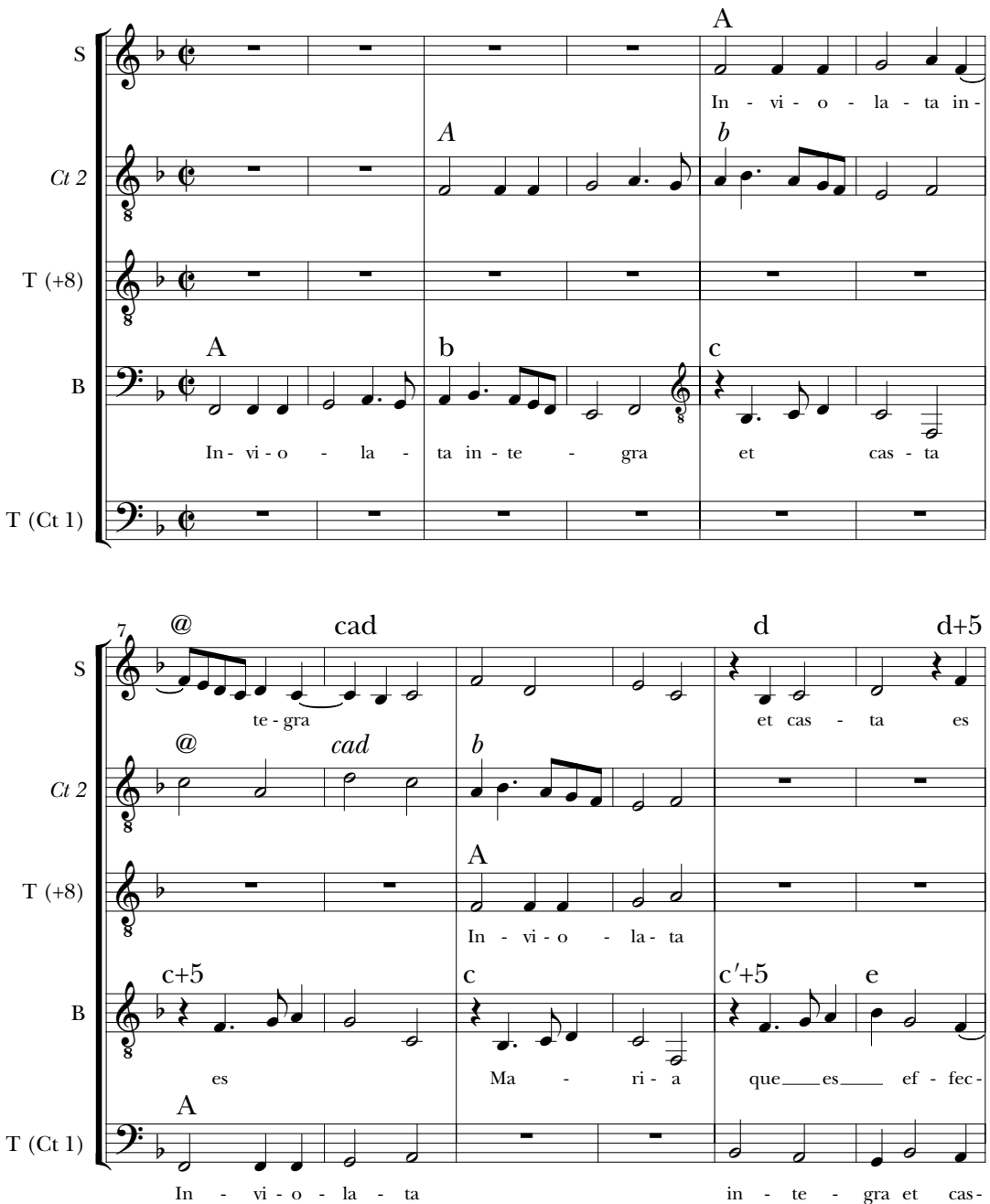

elements of the module in order to create a point of imitation (PEn). In the next section I show how Isaac uses modular construction in a work with a noncanonic cantus firmus.

\section{Alma redemptoris mater}

In Alma redemptoris mater the chant cantus firmus stays in the tenor throughout (for the complete score, see appendix III). ${ }^{21}$ The tenor

21 In Appendix III the motet is transcribed from Motetti $C$ with note values halved. 
EXAMPLE 7. (continued)

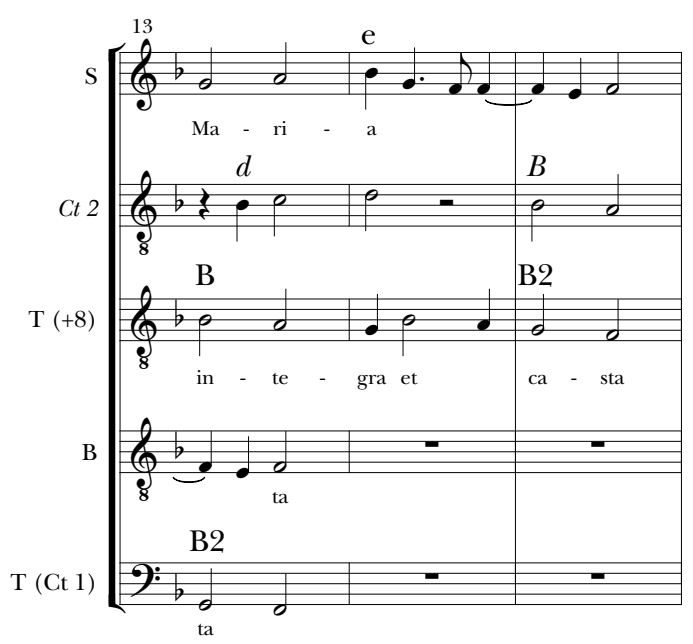

TABLE 7

Inviolata, diagram of mm. 1-15, with Ct 2

\begin{tabular}{|c|c|c|c|c|c|c|c|c|}
\hline $\mathrm{Mm}$. & $1-2$ & $3-4$ & $5-6$ & $7-8$ & $9-10$ & $11-12$ & $13-14$ & 15 \\
\hline Text & \multicolumn{5}{|c|}{ Inviolata } & \multicolumn{3}{|c|}{ integra et casta } \\
\hline $\mathrm{S}$ & & & $\mathrm{A}$ & @ & $@$ & $\mathrm{~d}$ & $d+5 e$ & $>$ \\
\hline [Ct 2] & & $A$ & $b$ & @ cad & $b$ & & $d$ & $B$ \\
\hline $\mathrm{T}(+8)$ & & & & & $\mathbf{A}$ & & B & B2 \\
\hline B & A & $\mathrm{b}$ & c & $c+5$ & c & $c^{\prime}+5 e$ & $>$ & \\
\hline $\mathrm{T}(\mathrm{Ct} 1)$ & & & & $\mathbf{A}$ & & B & B2 & \\
\hline
\end{tabular}

alternates between paraphrase and long-note treatment of the chant (shown with boxes in fig. 1), and passages of rest (marked with an "R" above the staff in fig. 1) ${ }^{22}$ This piece therefore allows us to learn about how Isaac composed imitative polyphony around both types of tenor treatment, and what he did when the tenor was resting. Because the long-note sections of the tenor take up so much less room on the page than in real time, their significance within the work is not immediately

22 The paraphrase technique used by Isaac in this piece is very free, so it is difficult to deduce which version of the chant he used. In the long-note sections, he often reduces the melody to its essentials (e.g., at "et stella maris," mm. 64-82; mm. 64-76 are ex. 9), but in the paraphrased sections he inserts many notes that are not in the chant. In any case, which version of the chant he used will not affect the argument here. 
THE JOURNAL OF MUSICOLOGY

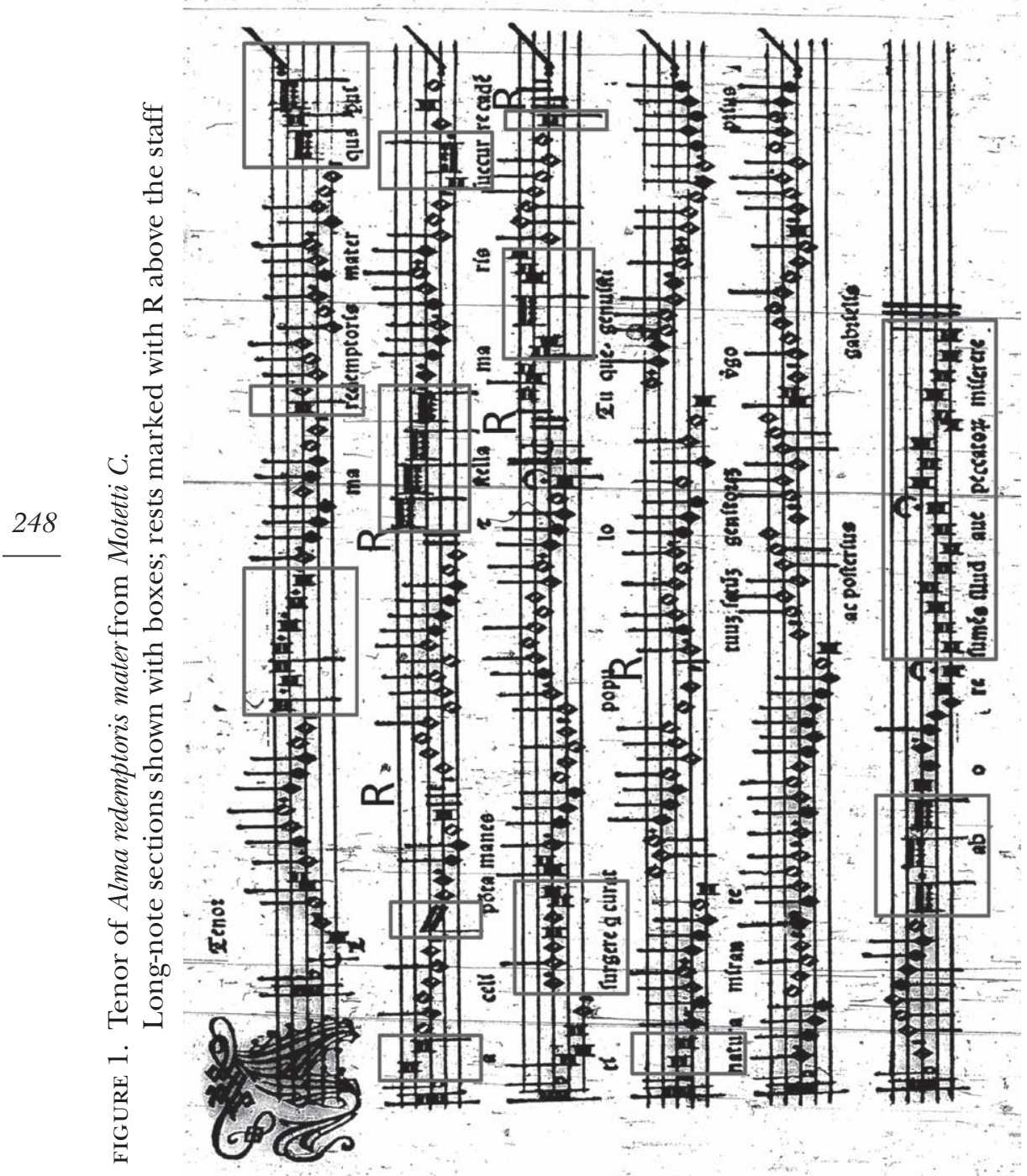


apparent in figure 1 . In fact, the long-note sections of the tenor take up a bit more than one third of the total length of the piece. ${ }^{23}$ Many phrases, especially in the prima pars, begin with long-note treatment and then end with chant paraphrase in smaller values; others use paraphrase technique throughout.

In order to represent Isaac's approach to composing around this cantus firmus, I have made a complete diagram of the piece in appendix IV showing the contrapuntal technique Isaac uses for each phrase. My classification of the various contrapuntal techniques is taken from the work of Peter Schubert. ${ }^{24}$ I examine selected excerpts from the piece, focusing on the ways in which Isaac uses modules and imitation. Choice of contrapuntal technique depends partly on the tenor treatment; but, as I show, modules and imitation appear with both long-note and chantparaphrase treatments of the cantus firmus.

\section{Modular Construction}

Isaac often repeats a four-voice contrapuntal module immediately, without variation. There is a very clear example of this procedure in example 8 (secunda pars, mm. 60-66). Here the cantus firmus is paraphrased very freely in the tenor, and its phrase is repeated exactly in the next three measures, presumably for the sake of the repeated module. The module itself is two-and-a-half-measures long, beginning on the second quarter note (minim) of measure 60 , and repeated in measures 64-66. All four voices are repeated exactly. The module includes exact imitation between the altus and tenor voices after one measure. I call this "Free Imitation for 2 voices" (FI-2) because imitation in two voices in itself does not necessarily involve a repeated module. ${ }^{25}$ The passage begins with weak cadential motion (lacking a 7-6 suspension between the superius and tenor, and with evaded resolution in the tenor and bass). In measure 65 it looks as though the module will be repeated a third time, but instead Isaac writes a correct 7-6 suspension, and all the voices resolve properly, providing a satisfying conclusion.

Isaac also often transposes his modules (usually by step, either up or down) and varies them; see example 9 . Here again is a four-

23 More precisely, 35 percent of the motet consists of the long-note sections (53 of the 111 breves in the prima pars_-just under half_and 24 of the 112 breves in the secunda pars, or 77 of the 223 breves in total).

24 See Schubert, "Hidden Forms" and Modal Counterpoint. I have also devised additional terminology for late fifteenth-century music, which is detailed in Julie E. Cumming, "Text Setting and Imitative Technique in Petrucci's First Five Motet Prints," in The Motet around 1500: On the Relationship of Imitation and Text Treatment, ed. Thomas Schmidt-Beste (Turnhout: Brepols, 2011; in press), 63-90.

25 See Schubert, "Hidden Forms," 514; and Cumming, "Text Setting and Imitative Technique," 78-82. 
EXAMPLE 8. Alma redemptoris mater, secunda pars, mm. 60-66. Four-voice modules around paraphrased cantus firmus, with FI-2 in $\mathrm{T}$ and $\mathrm{A}$

$\mathrm{S}$

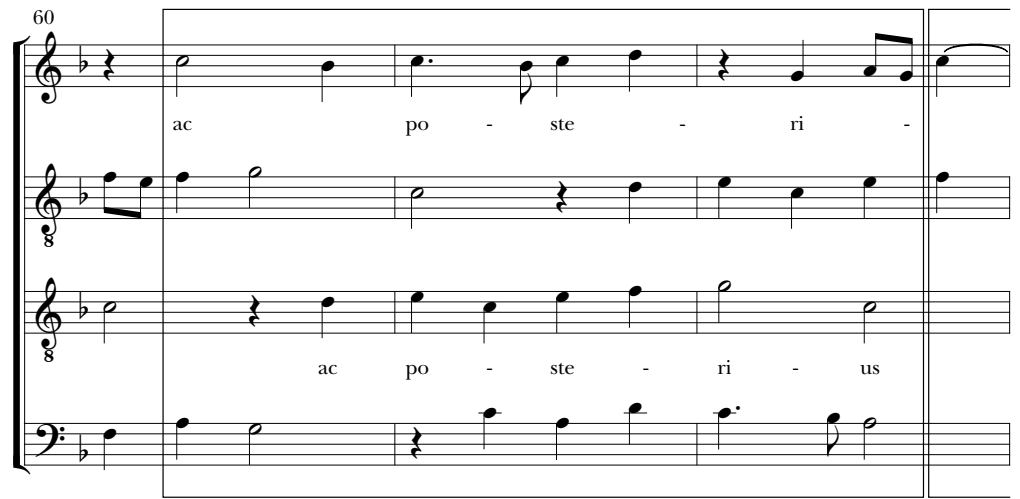

$\mathrm{S}$

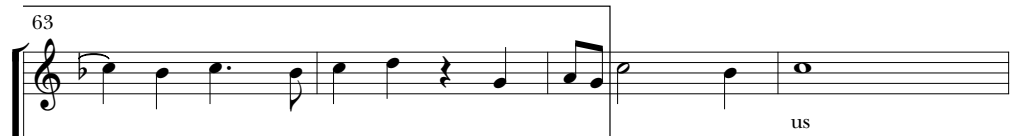

A

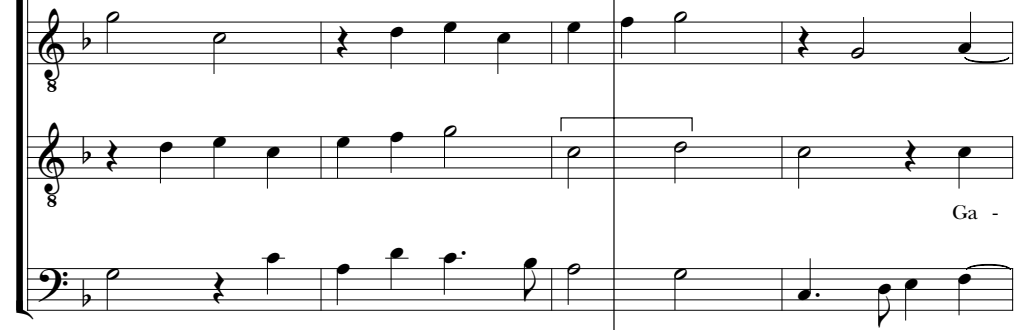

voice module, but now it is transposed down a step at each repetition, around a long-note cantus firmus that descends stepwise every four measures in the tenor. Because the repetition with transposition of all four voices results in a kind of harmonic sequence, I call it modular sequence ("mod seq" in appendix IV). ${ }^{26}$ Modular sequences of this kind are common in Isaac's music, and they can be exciting to hear and perform. The first two modules are almost exactly the same (the very beginning is different because of the lead-in from the previous

26 Schubert calls such repeated modules "repeated blocks" (see his "A Lesson from Lassus: Form in the Duos of 1577," Music Theory Spectrum 17 [1995]: 13) and refers to them as a kind of "harmonic sequence" because the intervals between the voices within the module or block remain the same. He finds that modular sequence is especially common at the ends of the two-voice ricercars. I also call modular repetition involving four voices "NIm-4"; on NIms, see note 29 below. 
section), but the melodic material in the third module is varied. Another example of a modular sequence in this piece is the descending sequence in the prima pars (mm. 13-18), with octave leaps in the bassus. I will discuss a third example below (prima pars, mm. 56-63 in ex. $17)$.

In example 9 the long-note tenor is accompanied by the bassus a tenth below (except for the last measure of the first two modules, where the bassus moves to a twelfth below). The consonances in the upper voices are therefore limited to notes of the root-position triad above the bassus. In the first two modules Isaac uses a motive based on movement from the root of the triad to the fourth below, with descending passing tones; since everything here is consonant, it is quite easy to organize it as FI-2 (imitation in two voices) at the octave. I call this "triadic FI-2" ("tri FI-2" in appendix IV) when it appears over one or more held notes, which is a very common technique in music composed in the decades around 1500. The variation in the third module puts the descending figure on the root $(\mathrm{B} b)$ and on the fifth $(\mathrm{F})$ of the triad, resulting in FI-2 at the fifth below between superius and altus in measures 74-76. There are quite a few other examples of triadic FI-2 in Alma redemptoris mater, all of them in the prima pars, where there is more long-note treatment of the tenor (mm. 7-9 in ex. 12; mm. 29-31, 76-79 and 87-90 in appendix III).

Cadential formulas, the repetitions of which are separated by contrasting music, are also modules. Cadential patterns are highly constrained: they are constructed around a two-voice contrapuntal sixthto-octave combination (or its inversion), with limited possibilities for contrapuntal motion in other voices. ${ }^{27}$ Most of the cadences in Alma redemptoris mater have a two-measure preface to the cadential arrival, characterized by one or more voices tied over the bar line in the modern edition (as in mm. 4-5 in ex. 12). This jaunty syncopated rhythm found before so many cadences is one of the features that gives this piece its overall character. ${ }^{28}$ One complete two-measure cadential passage from the prima pars (mm. 26-28 in ex. 16) returns slightly varied in the $s e$ cunda pars (mm. 32-34 in ex. 15). It thus functions as a four-voice module, although its two iterations are separated by more than a hundred measures. The recurring rhythmic pattern, subtly varied each time, also points toward the modular character of the cadential counterpoint.

27 See Schubert, Modal Counterpoint, 195-98, 256-57, and Cumming, The Motet in the Age of Du Fay, 76-77. In Appendix IV I have put the term "cad" in the measure before the cadential arrival.

28 The rhythm is either an offbeat semibreve or an offbeat dotted minim in the original notation. See mm. 36-37 and 39-40 in ex. 10; mm. 4-5, 6-7, and 8-9 in ex. 11; $\mathrm{mm}$. 52-53 in ex. 13, mm. 19-20 in ex. 14; and mm. 52-53 and 62-63 in ex. 17. Only two of the sixteen cadences in the prima pars are not preceded by this rhythm (cadences at mm. 39 
THE JOURNAL OF MUSICOLOGY

EXAMPLE 9. Alma redemptoris mater, prima pars, mm. 64-76. Modular sequence, with triadic FI-2 at the octave over long-note tenor
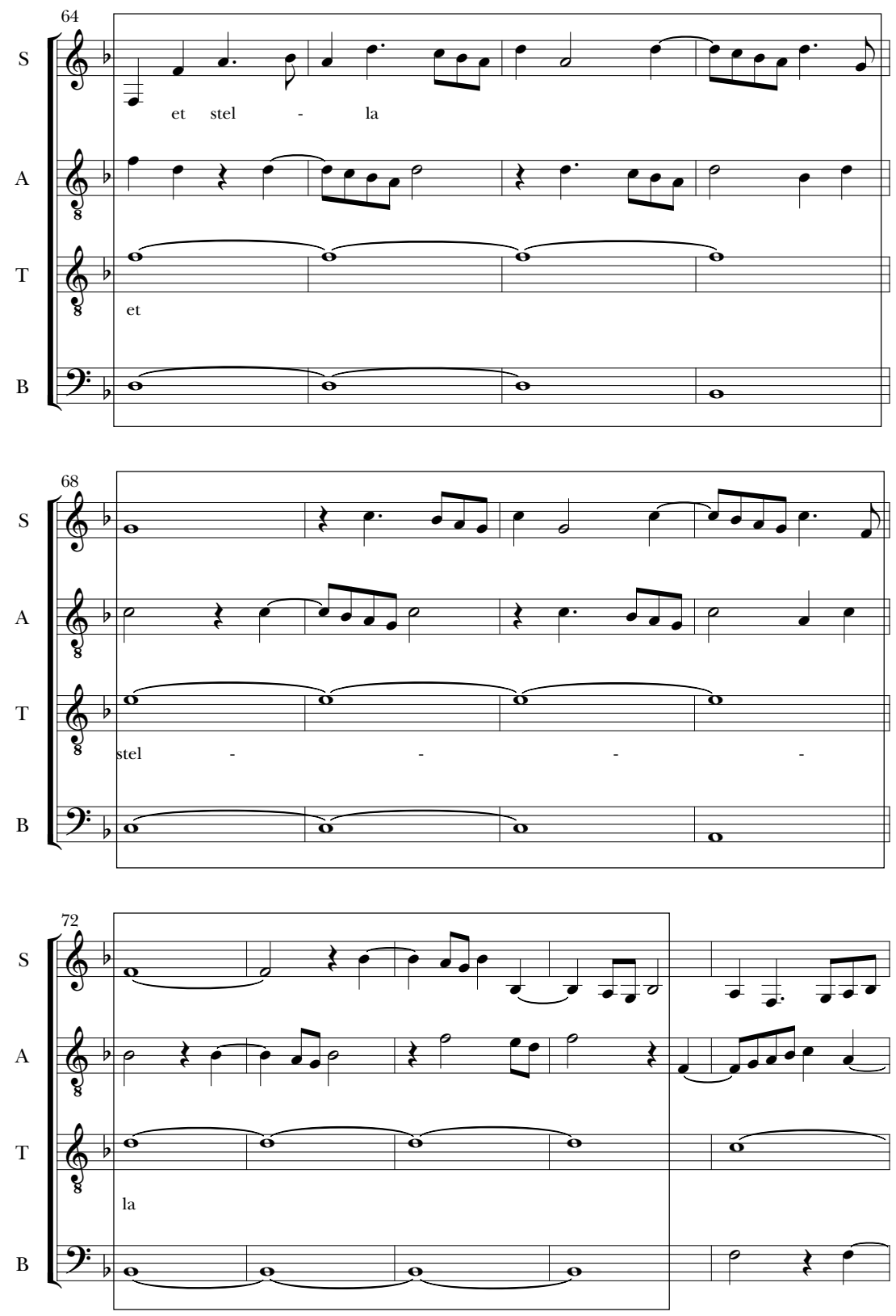
EXAMPLE 10. Alma redemptoris mater, secunda pars, mm. 35-41. Non-Imitative module (NIm)
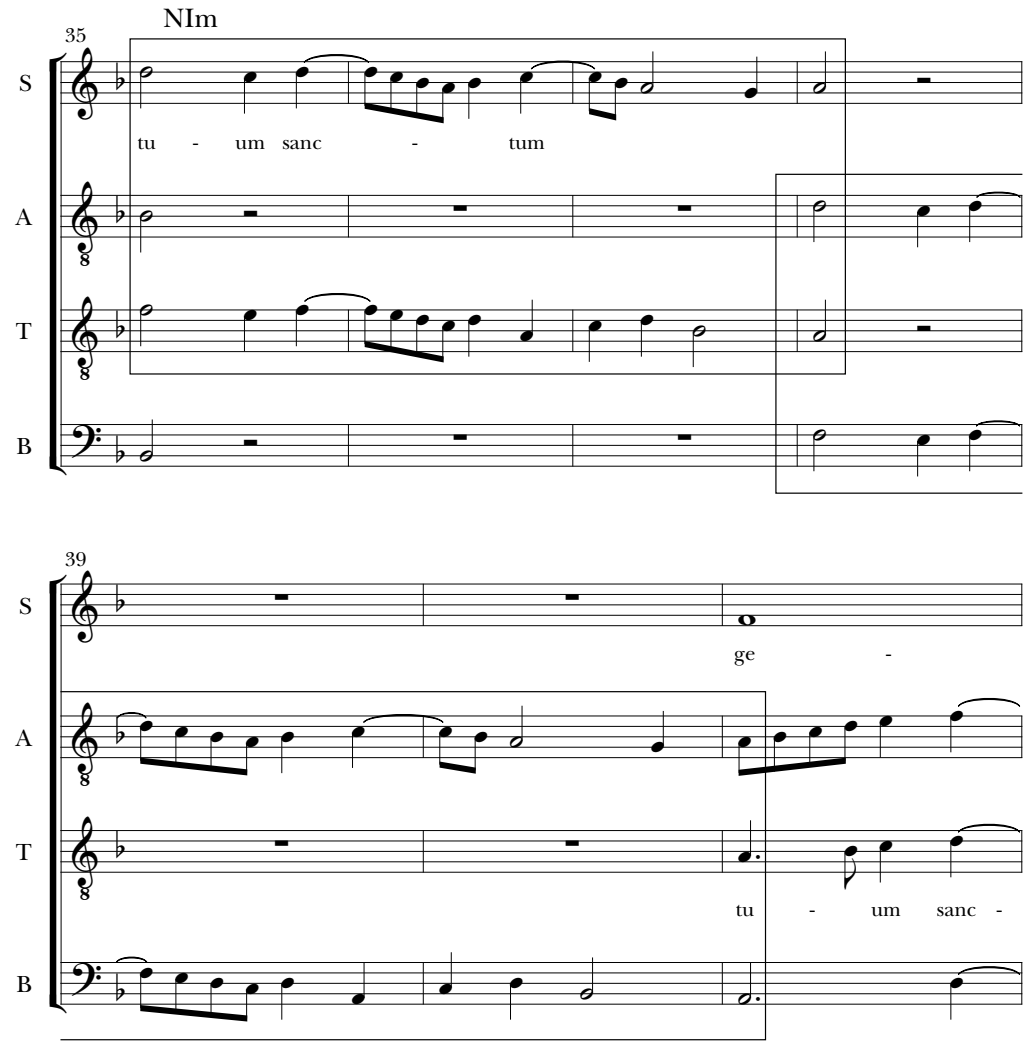

Most of the modules I have discussed so far involve repetition of complete chunks of music in all four voices. Other uses of modules derive from the presentation types of imitative polyphony, in which voices enter one at a time or in pairs. One of the simplest uses of modules appears in paired duos (ex. 10). Schubert calls this presentation type a "Non-Imitative module" or NIm, because the module itself does not include imitation. A NIm can be considered a form of imitative polyphony, however, since the module is presented first in one pair of voices and then repeated (or imitated) in the second. ${ }^{29}$ Here Isaac has the paraphrased tenor in the first NIm, then repeats the tenor melody in the bassus. The NIm itself consists primarily of parallel sixths, which cease at the approach to the cadence.

and 91). Only seven of the twenty-three cadences in the secunda pars are not preceded by this rhythm (cadences at mm. 17, 28, 66, 93, 99, 107, and 109).

29 On Non-Imitative modules (NIms), see Schubert, "Hidden Forms," 488, figure 1a, and 490-95. 
The set of Periodic Entries, or PEn, which we have already seen at the beginning of Inviolata, is one of the most common imitative presentation types ca. 1500; here it is used at the beginning of the secunda pars of Alma redemptoris mater (ex. 11).$^{30}$ Isaac builds his PEn by rhythmicizing the first few notes of the chant melody ( Tu que genuisti) into two segments (labeled $A$ and $B$ in ex. 11) that can be combined vertically, as in measures 3-4. He then tacks a cadential suspension (labeled $\mathrm{C}$ ) on to the end of the noncantus-firmus voices so that the module incorporates cadential motion. As in Inviolata, the altus, bassus, and tenor use Vorimitation. Once again the horizontal elements of the soggetto, A, B, and C, also combine vertically to make a module in measures 5-6 and 7-8. (The altus also adds free material in ex. 11, mm. 4 and 6-8.) The tenor, including only A and B, enters last and moves to long-note style at the end of the set of modules.

\section{Nonmodular Compositional Techniques}

Isaac also uses nonmodular techniques for composition, some of them closely related to techniques for improvisation of vocal polyphony. At the very beginning of Alma redemptoris mater there is a short passage of two-voice imitation (FI-2) between the tenor cantus firmus and the superius (mm. 1-4 in ex. 12). For other examples of FI-2, see the altus-tenor FI-2 within the repeated four-voice module in example 8 , and the triadic FI-2 in the modular sequence in example 9. These are examples of a nonmodular technique included in a module. Another example of triadic FI2 , which is not part of a repeated module, appears in measures 7-9 of example 12. This passage begins with strict FI-2 after a half note (semibreve) between the bassus and the altus, but quickly breaks off, retaining, though, its triadic shape. I use the term triadic FI-2 to describe this kind of loose imitative triadic writing around a held note even when the imitation is not exact throughout.

Because of the short time interval between the entries, John Milsom dubbed a particular kind of FI-2 stretto fuga. ${ }^{31}$ Stretto fuga is a type of canon after one time unit (minim, semibreve, breve) that Isaac may have learned to improvise as a choirboy. When the lead voice follows the rules

30 See ibid. 488, figure 1c, and 498-504.

31 On stretto fuga in two voices, see John Milsom, “'Imitatio,' 'Intertextuality,' and Early Music," in Citation and Authority in Medieval and Renaissance Musical Culture: Learning from the Learned, ed. Suzannah Clark and Elizabeth Eva Leach (Woodbridge: Boydell Press, 2005), 146-51. Milsom explains the rules for stretto fuga at the fifth. See also Schubert, Modal Counterpoint, 156-59. For stretto fuga for more than two voices, see idem, "From Improvisation to Composition: Three Case Studies," in the eleventh publication of the Collected Writings of the Orpheus Instituut (Leuven: Leuven University Press, forthcoming). For an even fuller discussion of the use of stretto fuga in the second half of the fifteenth century, see Julie Cumming and Peter Schubert, "Patterns of Imitation, 1450-1508," presented at a conference on Medieval and Renaissance Music, Utrecht, the Netherlands, 1 July 2009; and at meeting of the American Musicological Society, Philadelphia, 13 November 2009. 
EXAMPLE 11. Alma redemptoris mater, secunda pars, mm. 1-10. Periodic Entries (PEn)
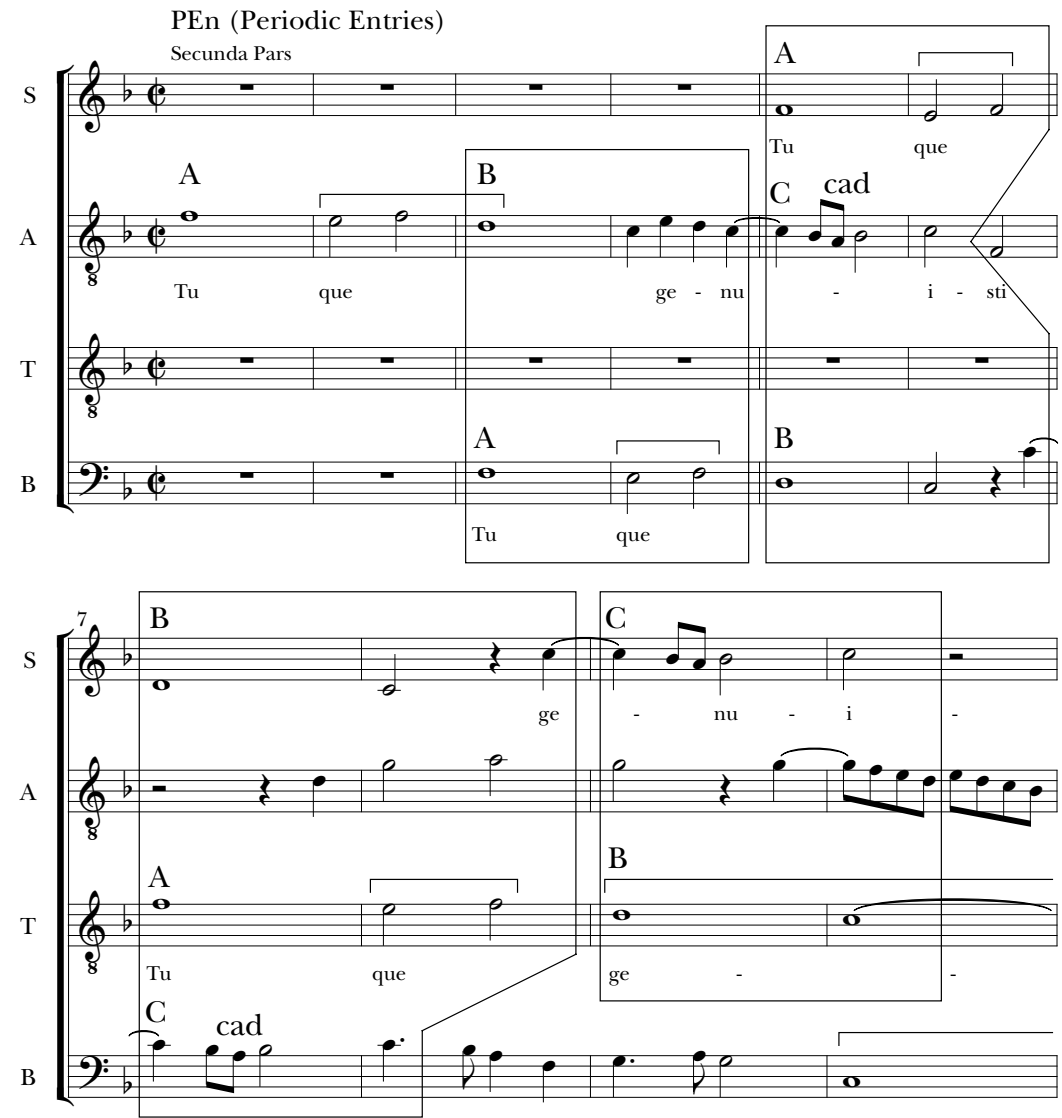

for melodic interval choice, the counterpoint works. ${ }^{32}$ In example 13 there are two embellished stretto fugas: one at the fifth above after a half note (semibreve) ( $\mathrm{mm} .46-52)$, and one at the fifth below after a half note (mm. 54-57). I call them embellished because they are not in strict note-against-note counterpoint at the level of the semibreve; instead, the

32 The basic rules for melodic interval choice in stretto fuga are as follows: at the fifth above and fourth below, one can go down even-numbered intervals (seconds, fourths, etc.) and up odd-numbered intervals (thirds, fifths, etc.). At the fifth below and the fourth above, one can go down odd-numbered intervals and up even-numbered intervals. Stretto fuga at the fifth can use unisons, stretto fuga at the fourth cannot (unless the stretto fuga is accompanied by a third voice). For stretto fuga at the octave and unison, one can go up and down thirds and sixths, and have unisons; at the octave above, one can go down one fifth and up one fourth; at the octave below, one can go down one fifth and up one fourth. 
EXAMPLE 12. Alma redemptoris mater, prima pars, mm. 1-10. Free Imitation in $\mathrm{S}$ and $\mathrm{T}$ (FI-2, mm. 1-4); Parallel 6ths in S and T (mm. 2-5); Triadic FI-2 in A and B (mm. 7-9)
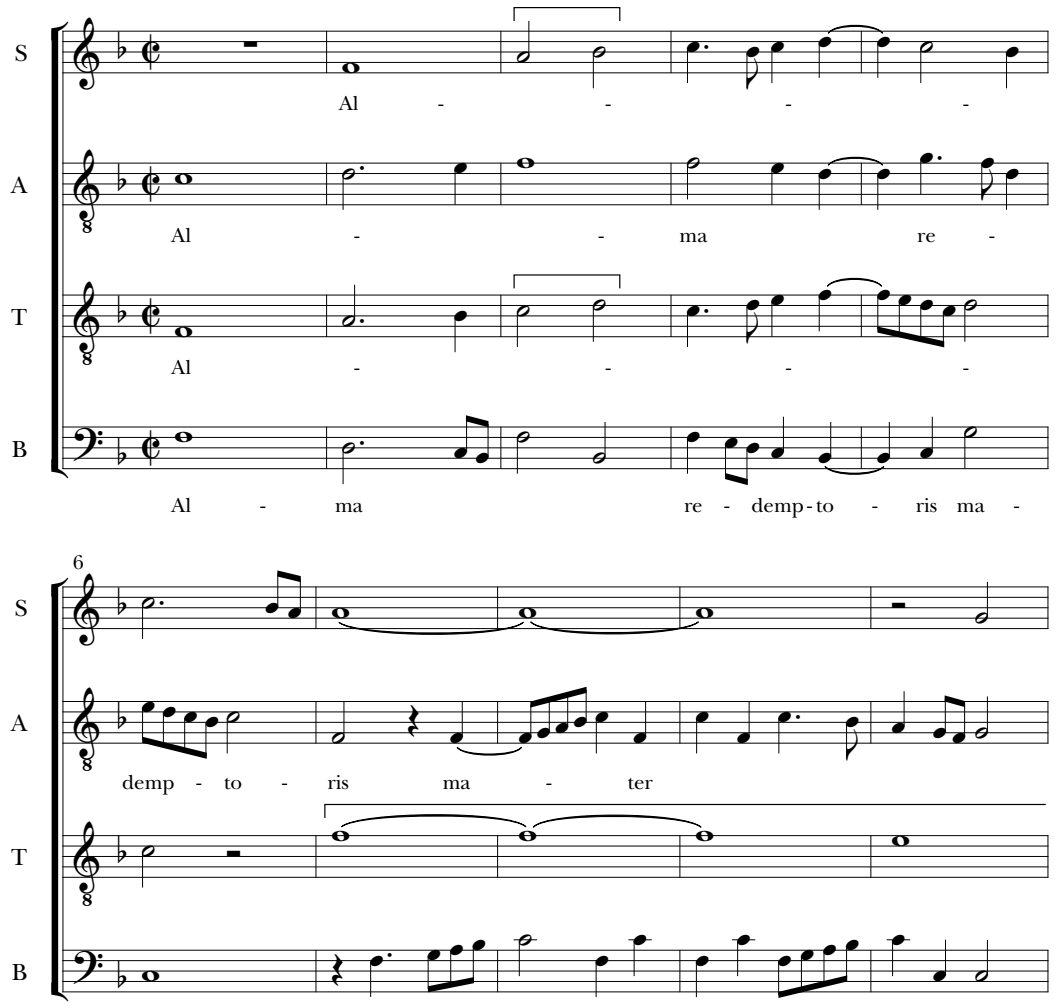

ter

semibreves (half notes) are broken up into smaller values. In both, the lower voice is doubled at the third above. In stretto fuga at the fifth above, the descending stepwise motion results in mostly parallel sixths between the outer voices, which, with the doubling, create fauxbourdon-like textures. In the brief passage of stretto fuga at the fifth below Isaac embellishes a single pitch with neighbor tones (mm. 54-57). ${ }^{33}$

In example 14 Isaac uses a passage in stretto fuga three times with variation. In the measures preceding this example the tenor sings long notes; at measure 18 Isaac switches to free paraphrase to make the cadence at the end of the phrase in measure 21. The tenor melody in

33 In example 13 the stretto-fuga passages are repeated, resulting in three-voice modules: $\mathrm{mm}$. 46-48 are repeated in mm. 49-51, transposed down a fifth ("mod seq" in appendix IV), and mm. 54-55 are repeated at the same pitch in mm. 56-57. 
EXAMPLE 13. Alma redemptoris mater, secunda pars, mm. 46-57. Stretto fuga with parallel thirds above the lower voice
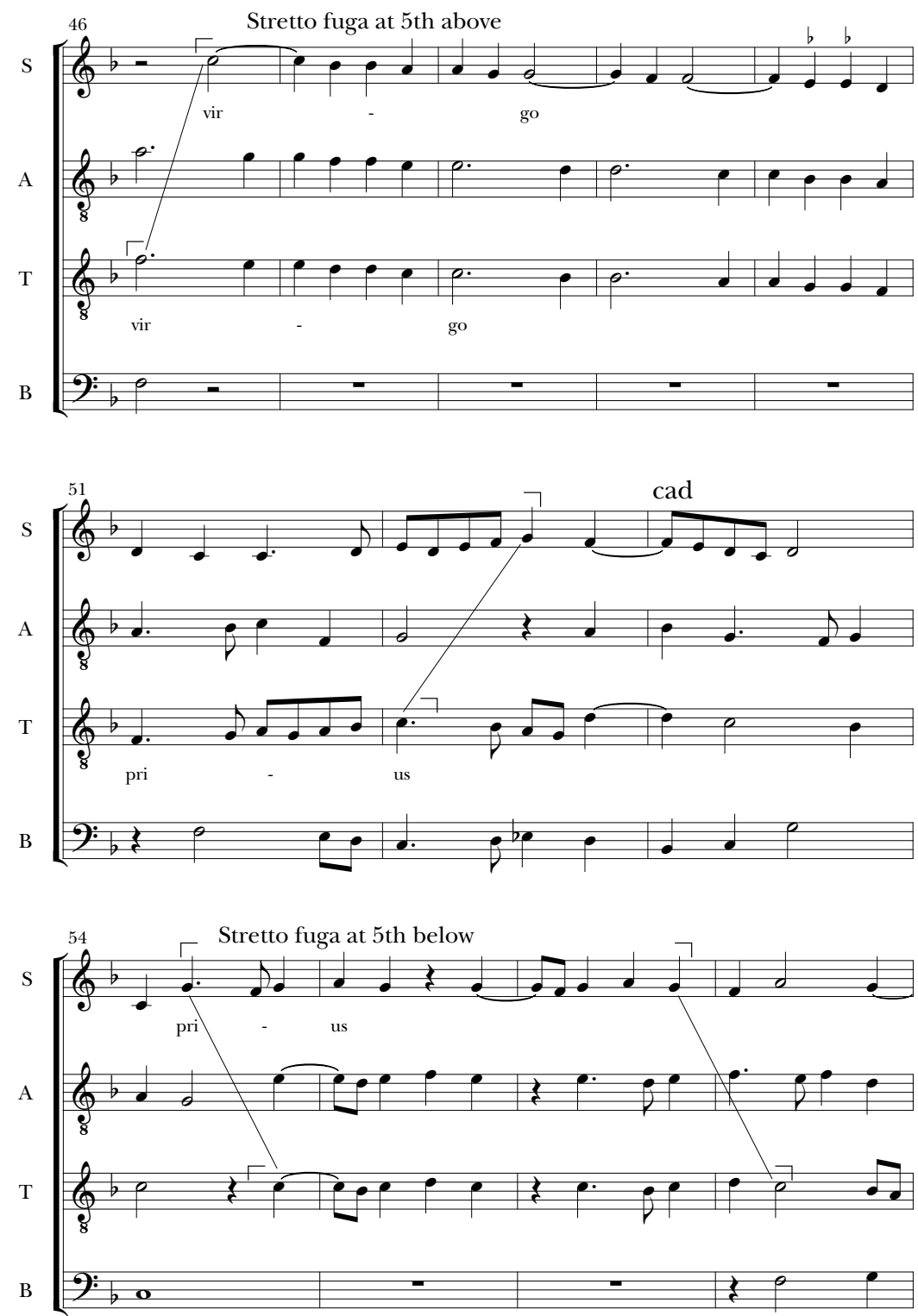
EXAMPLE 14. Alma redemptoris mater, secunda pars, mm. 18-28. Stretto fuga for two voices ( $\mathrm{T}$ and $\mathrm{B}, \mathrm{mm} .18-20)$, three voices (A, B, and $\mathrm{S}, \mathrm{mm} .21-23$ ), and two voices again (A and $\mathrm{B}, \mathrm{mm}$. 24-27)

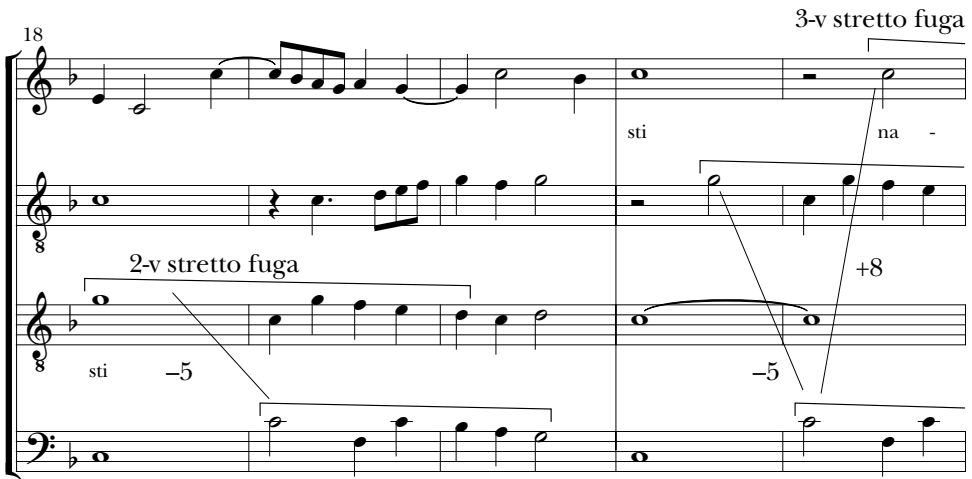

$\mathrm{S}$

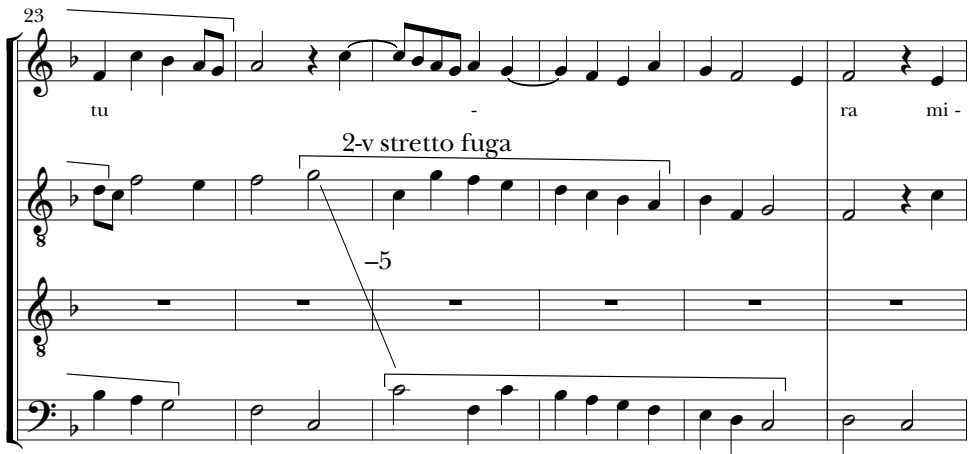

measures 18-20 functions as the dux in an embellished stretto fuga at the fifth below, with the bassus serving as comes, leading to a strong cadence on $\mathrm{C}$. The freedom of chant-paraphrase technique combined with the flexibility of embellished stretto fuga makes it possible to use almost any chant melody in an imitative passage. ${ }^{34}$

In the next phrase, beginning in measure 21, the tenor holds the cadential arrival pitch and then drops out. In measures 21-23, however,

34 See Schubert and Cumming, "Chant-Paraphrase Canon: Straitjacket or Instinctive Behaviour?" presented at the Medieval and Renaissance Music Conference, Barcelona, 6 July 2011. For a good example of the use of chant paraphrase in stretto fuga, see Owens's discussion of Isaac's Sanctissimae virginis votiva festa in Composers at Work, chap. 10, 258-90, esp. 262-67. Isaac paraphrased his chant so that he could use it in canon with itself at the fourth above and at the octave below. Isaac also uses parallel sixths and parallel tenths between outer voices in some phrases of Sanctissimae virginis. 
the soggetto of the stretto fuga is taken up by the altus and the bassus (which repeat the original two-voice stretto fuga), and the added superius (which enters an octave above the bassus) ${ }^{35}$ Finally, in measures 24-27, the altus and the bassus repeat the original two-voice stretto fuga, along with the original superius from measure 19, now with an extended downward scale that leads to a cadence on F. While a two-voice stretto fuga is not modular in itself, Isaac's repetition of the original stretto-fuga combination makes the passage into a module. The module is heard three times, varied each time with different counterpoint in the other voices, and ending with different conclusions. The rests in the tenor (mm. 23-28) provide an opportunity to repeat the stretto-fuga combination without having to combine it with the cantus firmus. ${ }^{36}$

Some other techniques used in Alma redemptoris mater include parallel sixths and tenths, which, like stretto fuga, are easy to improvise. Parallel imperfect intervals are incorporated into modules (NIms using parallel sixths in ex. 10), but they are also used for nonmodular passages. Parallel sixths could be used in both fauxbourdon and what Schubert calls the parallelsixth model, in which superius and tenor have parallel sixths over a bassus with thirds, fifths, and octaves below the tenor. ${ }^{37}$ The Free Imitation for two voices (FI-2) at the opening of the motet leads to parallel sixths, which are continued until the cadence in measure 6 (ex. 12 above). The bassus uses only unisons, fifths, octaves, and tenths (compound thirds) below the tenor in this passage. Using parallel tenths in the outer voices was such a common technique in this period that Gaffurius called it "celeberrimus

35 On three-voice invertible canon, see Schubert, Modal Counterpoint, 227-36. Threevoice stretto fuga is actually a type of PEn (Periodic Entries), so it is a modular imitative presentation type. I thought it made more sense to discuss it here, however, in relation to two-voice stretto fuga.

36 There are five passages in Alma redemptoris mater in which the tenor rests for more than a breve. One is the opening of the secunda pars, where the tenor comes in last after Vorimitation in the other voices (ex. 11). Two are repeated two-voice Non-Imitative modules (prima pars, mm. 50-54, and secunda pars, mm. 38-40 in ex. 10), in which the tenor drops out for the repeated duo in the other pair of voices, varied by transposition (up an octave in the prima pars, down an octave in the secunda pars). The other two passages in which the tenor rests (secunda pars, mm. 23-29, ex. 14 and mm. 60-63, ex. 17) will be discussed below; in both cases Isaac varies contrapuntal combinations initially involving the tenor.

37 On fauxbourdon, see Brian Trowell, "Faburden and Fauxbourdon," Musica disciplina 13 (1959): 43-78; Anna Maria Busse Berger, Medieval Music and the Art of Memory (Berkeley: University of California Press, 2005), 200-10; Schubert, Modal Counterpoint, 190-92. On the parallel-sixth model, see ibid., 189-94, 243-46; there is also the option of an altus alternating thirds and fourths above the tenor. Parallel sixths can also be inverted to create parallel thirds, a technique described by Guilielmus Monachus, De preceptis, ed. Seay, Book VI, 41; and Park, “'De preceptis,"” sentences 53-58 (Latin: 69; English: 188). See also Klaus-Jürgen Sachs, Der Contrapunctus im 14. und 15. Jahrhundert: Untersuchungen zum Terminus, zur Lehre und zu den Quellen (Wiesbaden: Franz Steiner Verlag GMBH, 1974), 137-38; and Markus Jans, "Alle gegen eine: Satzmodelle in Note-gegen-Note-Sätzen des 16. und 17. Jahrhunderts,” Basler Jahrbuch für historische Musikpraxis 10 (1986): 101-20. 
EXAMPle 15. Alma redemptoris mater, secunda pars, mm. 30-34 Parallel tenths between outer voices; cadential module, mm. 32-34 (compare ex. 16, mm. 26-28)

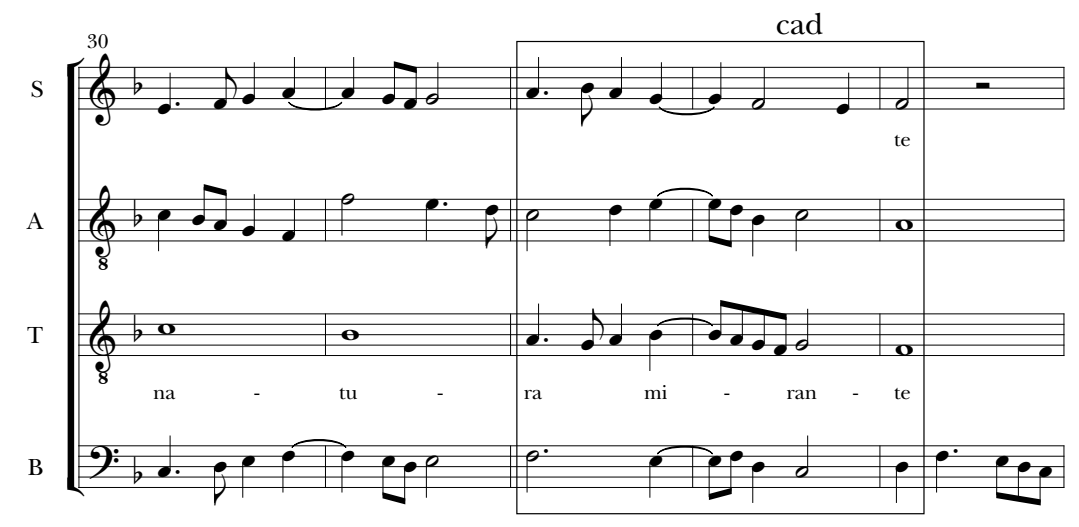

... processus notularum" (a certain very famous progression of notes).$^{38} \mathrm{It}$ occurs often in Alma redemptoris mater (mm. 30-34 in ex. 15). The parallel tenths serve as accompaniment to a descending long-note passage in the tenor and then accompany the chant paraphrase leading to the cadence. Even when Isaac is not using imitation, modules, or parallel motion, he relies on repeated material in a single voice over held notes in the tenor, as in the melodic sequence over a held note ( $\mathrm{mm} .22-25$ in ex. 16). ${ }^{39}$

\section{Imitation, Cadence, and Module}

As we have seen, several of Isaac's modules incorporate cadences (exs. 8, 10, and 11) ${ }^{40}$ An especially ingenious example of the cadence constituting the module is presented in example 17 (prima pars, $\mathrm{mm}$. 52-64). These measures combine an extended passage of FI-2 between the superius and the bassus with repeated cadential patterns and transposed modules. The FI-2 begins in the superius (mm. 56-63); the bassus

38 Gaffurius, Practica musice (Milan, 1496), Book IV, chap. 12; English trans. Clement A. Miller in Gaffurius, Practica musicae (American Institute of Musicology, 1968), 144-45. For a full explanation of the technique, see Schubert, Modal Counterpoint, 193-94. There are several other places in Alma redemptoris mater with parallel tenths in the outer voices (see prima pars, mm. 31-34, 41-44, 52-55, and 98-100).

39 Sometimes Isaac also uses a single triadic melody, usually including some repeated motives, over a held note or notes (see the altus voice in the prima pars, mm. 35-38, with the repeated CGC and then two stepwise descents through a fourth-C down to G and A down to $\mathrm{E})$.

40 Andreas Pfisterer focuses on the role of cadential motion in Isaac's imitative technique in "Imitationstechniken bei Isaac," 91-94. 
EXAMPLE 16. Alma redemptoris mater, prima pars, mm. 22-28. Melodic sequence over long-note tenor (S, mm. 22-25); cadential module (mm. 27-28; compare ex. 15, mm. 32-34)

$\mathrm{S}$
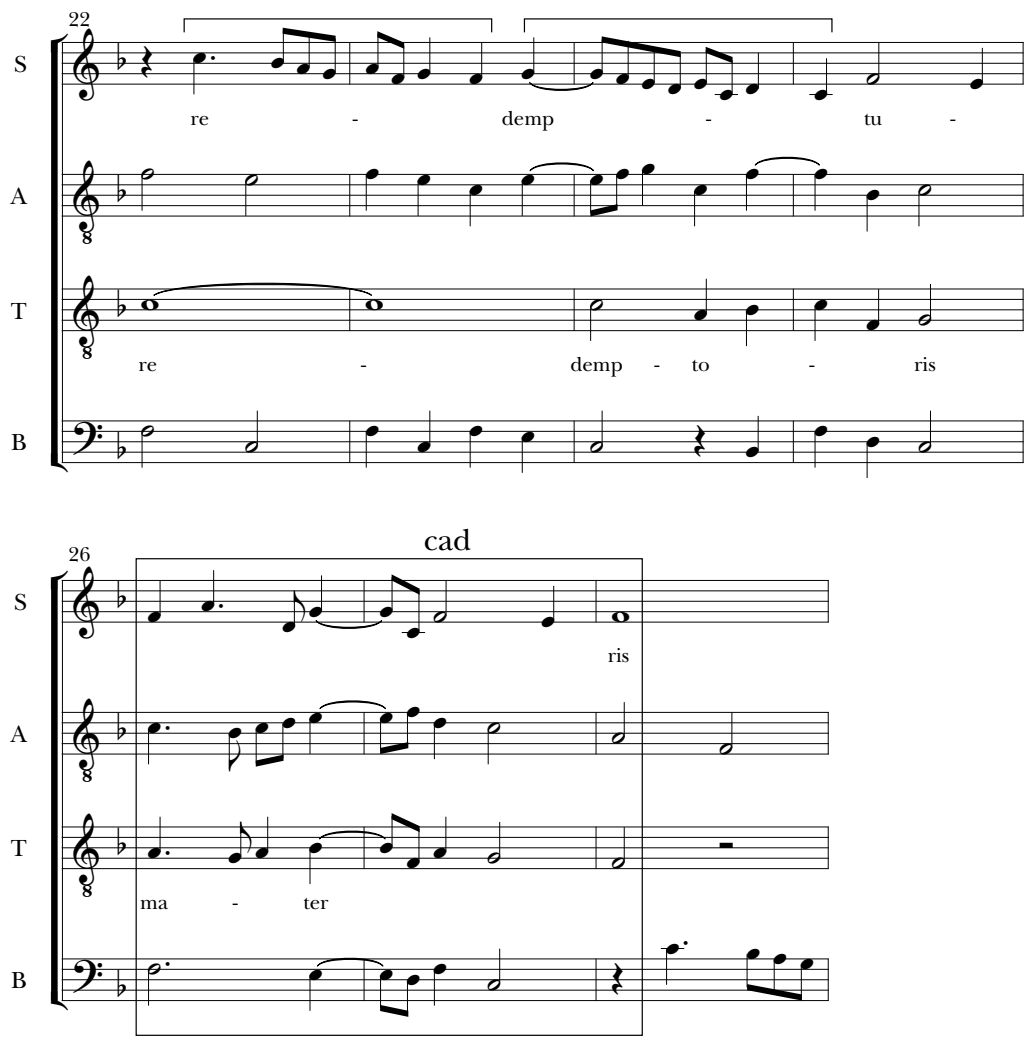

follows after one measure, an octave below. The melody treated in imitation is made out of alternating melodic units derived from cadential functions: "a" is the cadential "modus suprani," as Guilielmus Monachus labels it, while "b1" (1-2-1) and "b2" (3-2-1) are the cadential "modus tenoris." The "a" phrase of the superius melody emerges seamlessly out of the gradual descending line in measures 52-56 as the cadential end to the phrase. It then quickly moves into an exciting trajectory up an octave and then down again, intensified by the truncated middle statement in measures 58-61.

The FI-2 between the superius and the bassus results in the vertical combination of "a" and "b," which form repeated cadential patterns. The tenor and the altus also play a role: the tenor provides the original "b" motive combined with the superius "a" (mm. 56-57) before the entry 
THE JOURNAL OF MUSICOLOGY

EXAMPLE 17. Alma redemptoris mater, prima pars, mm. 52-64. FI-2 (S \& B), cadences, and modules

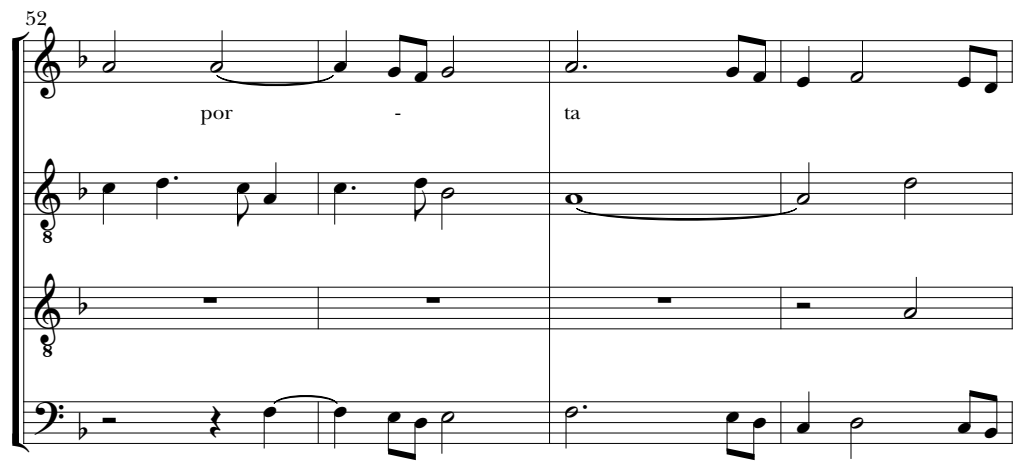

A
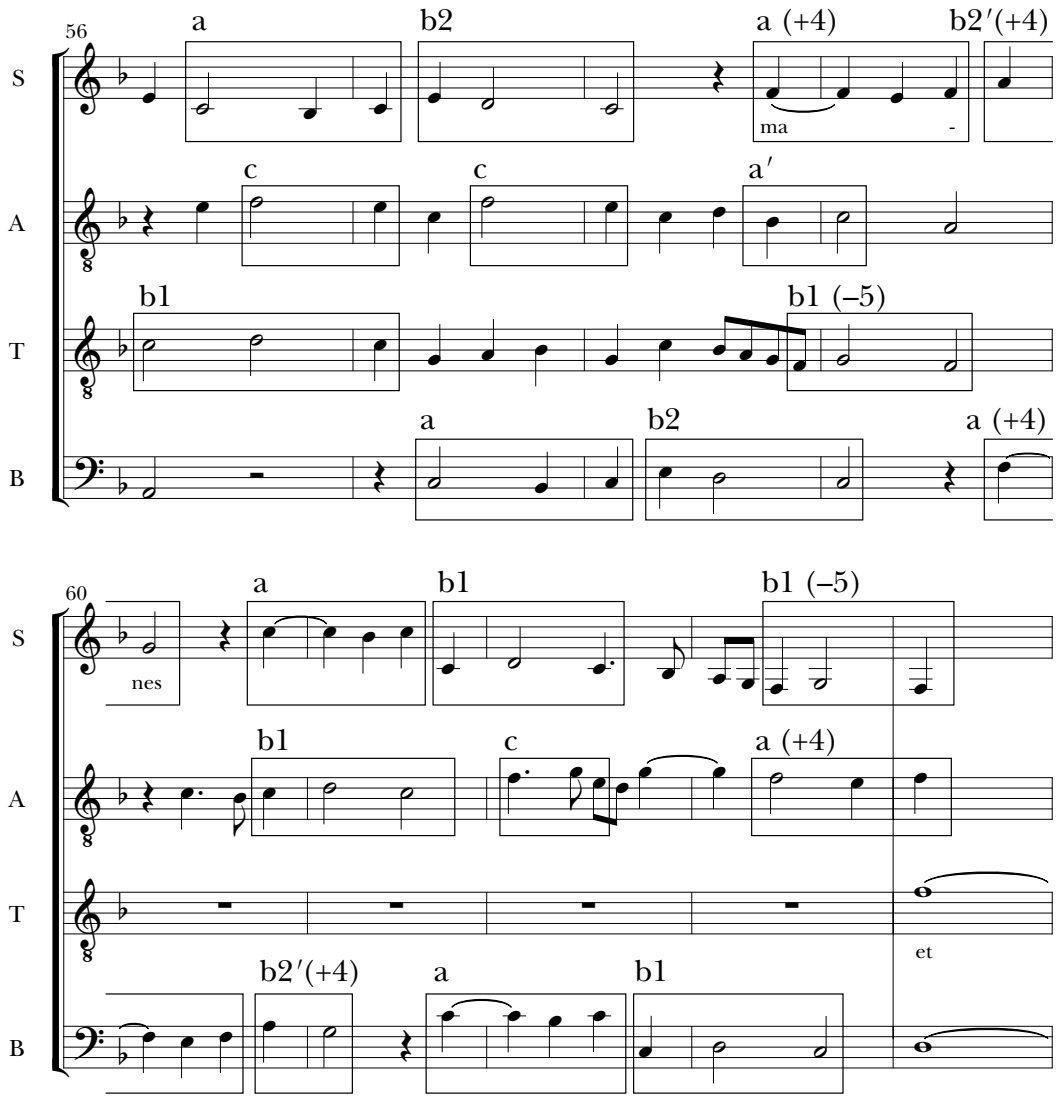
of the bassus; it then performs a similar role in measure 59 for the first cadence on F. The altus, meanwhile, provides the 4-3 harmonization (labeled "c") in measures 56, 57, and 62, as well as another "b1" in measure 61, and the "a" that creates the final $\mathrm{F}$ cadence in the passage. The cadential module that combines "a" and "b1" or "b2" occurs seven times over the course of eight-and-a-half measures. After all these cadences, the "deceptive" bassus motion to D in measure 64 provides a satisfying contrast and moves the motet forward into the next section.

\section{Large-scale Form}

Most of the musical material in these two motets by Isaac is repeated: most often the repetitions occur immediately, although frequently in another voice and transposed by an octave, fifth, or twelfth. ${ }^{41}$ In spite of this overwhelming amount of repetition, there is also variety. In Inviolata Isaac carefully provides different counterpoint to repeated melodies in the cantus firmus in most cases, including all four of the F repetitions (appendixes I and II); in Alma redemptoris mater Isaac usually chooses different contrapuntal techniques for adjacent phrases (appendix IV). In each piece, however, he also repeats contrapuntal combinations or techniques after many measures, creating large-scale formal structures.

The overall form of Inviolata is represented in table 8. The shaded letters indicate places where the repeated modules are not adjacent, or extend beyond the pairs of two-measure units defined by the canonic tenor. The first example is associated with the $\mathrm{C}$ melody in the tenor at the ends of the versicles in the first pair, where the combination $\mathrm{f} / \mathrm{C}$ ( $\mathrm{f}$ over C, mm. 16-19) returns eleven measures later in measures 27-30. ${ }^{42}$ Here Isaac uses repetition to link the two versicles and to round out the thirty-measure introduction.

The second example of large-scale modular repetition involves the music first heard over the tenor melody A'-B', a seven-measure passage that is repeated in all voices after almost thirty measures. Isaac paraphrases the Inviolata chant so that A' is an ornamented version of $\mathrm{F}$, and B' is identical with F2 (mm. 22-26, and mm. 57-61 in ex. 1); by doing so, he links the A melody heard at the beginning of the motet with the F melody that is heard four times in the second half, and makes modular repetition possible. ${ }^{43}$ The melodies in the other voices are also the same: $\mathrm{s}$ and $\mathrm{t}$, the

41 This is typical of music ca. 1500; see my article "From Variety to Repetition: The Birth of Imitative Polyphony," in Yearbook of the Alamire Foundation 6, ed. Bruno Bouckaert, Eugeen Schreurs, and Ivan Asselman (Peer, Belgium: Alamire, 2008), 21-44, http:// alamirefoundation.org/en/papers/yearbook-6.

${ }^{42}$ Melody $\mathrm{f}$ is varied slightly when it returns in $\mathrm{mm}$. 27-29, so I have named it $\mathrm{j}\left(\mathrm{f}^{\prime}\right)$; the other voices in $\mathrm{mm}$. 27-29 are not the same as in $\mathrm{mm}$. 16-19 (appendixes I and II).

${ }^{43}$ The label $\mathrm{A}^{\prime}\left(\mathrm{F}^{*}\right)$ indicates the relation of this phrase to both $\mathrm{A}$ and $\mathrm{F}$. It is $\mathrm{A}^{\prime}$ because it starts with the same rhythm as A and ascends stepwise, and because it corresponds to A in 
TABLE 8

Overall structure of Inviolata

\begin{tabular}{lll} 
Mm. & Paired versicles in canonic tenors & \\
\hline $1-30$ & 1. A, B-B2, C / A'-B', C & Introduction \\
31-54 & 2. D, C, E / D, C, E & Continuation \\
$55-99$ & $\begin{array}{l}\text { 3. F-F2(B'), G-G2 / F-F3, G-G3 } \\
\text { 4. F-F4, H / F-F5, H' }\end{array}$ & B section \\
$100-117$ & 5. I-I2 / I'-I2' / I'-I2 & Conclusion \\
\hline
\end{tabular}

Shaded sections represent repeated modules

tunes found with F-F2 (ex. 3), bring back g and h, the tunes found with A'-B' (mm. 20-26 and 55-61 in appendixes I and II). The recurrence of this module thus serves to articulate the beginning of the second half.

At the end of the piece (mm. 100-114) Isaac links the three I-I2 melodies in a continuous chain (appendixes I and II). He creates an extended passage of FI-2 between the superius and the bassus that shadows the canon in the cantus-firmus voices. The first unit (mm. 100-104) is different, but the music in mm. 105-109 is almost exactly repeated in $\mathrm{mm}$. 110-114. With a kaleidoscopic sequence of modules using I, I2, cc, $\mathrm{dd}$, and ee, this orgy of repetition provides a strong conclusion to the motet. Moreover, the repetition of measures 105-109 in measures 110114 recalls the use of a repeated final phrase in many sixteenth-century chansons and madrigals.

Large-scale repetition is harder to find in Alma redemptoris mater than in Inviolata, in part because there is less repetition in the chant melody. In Alma redemptoris mater Isaac shapes the form largely through tenor treatment and textural contrast. ${ }^{44}$ The two partes are differentiated by tenor treatment (fig. 1). There is more long-note tenor treatment in the prima pars, and more paraphrase in the secunda pars. Isaac links the prima and secunda partes by bringing back the two-measure cadential passage at a similar point in each pars $(\mathrm{mm} .26-28$ in the prima pars returns at $\mathrm{mm}$. 32-34 in the secunda pars, see exs. 16 and 15).

Isaac uses textural change to indicate the middle and the end of the piece. He ends the prima pars with reduced texture, as if to tell us that the piece is not yet over. The secunda pars begins with rests in the tenor, making possible a classic opening move: Vorimitation in a

\footnotetext{
the paired-versicle structure. It is $\mathrm{F}^{*}$ because it is an ornamented version of $\mathrm{F}$ (filling in the leap of a third, and ascending to $\mathrm{B} b$ that never actually appears elsewhere in the piece). I use $\mathrm{F}^{\prime}$ as the label for a varied version of $\mathrm{F}$ that appears several times in my $\mathrm{Ct} 2$ part.

${ }^{44}$ Schubert has identified musical features associated with the beginnings, middles, and ends of pieces in "A Lesson from Lassus."
} 
set of Periodic Entries (PEn) (ex. 11). To lend a strong conclusion to the piece, he provides us with two different concluding sections. Many pieces from the second half of the fifteenth century end with a triplemeter section-Isaac's ending involves an ABAB' modular repetition ( secunda pars, mm. 78-93 in appendixes III and IV). As if that was not enough, he follows the triple-meter section with a homorhythmic section in equal breves, a texture never before heard in the piece $(\mathrm{mm}$. 94-112 in appendixes III and IV).

\section{Conclusion}

Isaac's Inviolata et casta es Maria and Alma redemptoris mater provide a guide to composing imitative counterpoint around a cantus firmus. Although given its strict canonic cantus firmus Inviolata is a special case, it does demonstrate modular composition in a very clear way. Alma redemptoris mater shows that Isaac used the technique of modular composition even with a cantus firmus in a single voice, and that he combined modules with the use of other standard contrapuntal techniques. Repetition abounds in both pieces-in fact, there is hardly a phrase that is not repeated.

We can imagine Isaac's compositional process as follows. In Inviolata he started by writing a multivoice contrapuntal combination: he took a brief section of a cantus firmus, gave it rhythms and possibly some ornamentation, worked out the canon, and then added the additional voices one at a time, adjusting them as necessary. Then he repeated the contrapuntal combination, either without change or varied by inversion, transposition, or melodic variants. Once repeated, the contrapuntal combination became a module. To create a point of imitation at the beginning of the piece, he lined up the elements of the module horizontally and brought the voices in one at a time. Then he wrote sets of modules one after another until the cantus firmus came to an end.

In Alma redemptoris mater Isaac used this modular approach to composition (with PEns and NIms, repeated modules, modular sequences) for large portions of the piece. He built his modules around the tenor cantus firmus, relying on both paraphrased and long-note forms. In some cases he took advantage of rests to repeat a module without the tenor, or moved the cantus firmus melody to another voice for the repetition of the module. He created and linked the modules with contrapuntal techniques such as the use of parallel imperfect intervals and stretto fuga that he had probably learned to improvise as a choirboy. Sometimes he built his cadential motion into the module, or he added a cadence to the end of a phrase.

A surprising conclusion emerges from this description of Isaac's process: composing around a cantus firmus is very similar to composing 
music without a cantus firmus. The only real difference is that with a cantus firmus the pitches of the first melody in the module (or the first and the second melodies, if there is overlap, as in some passages of Inviolata) are predetermined, whereas without a cantus firmus the composer creates the first melody on the spot. This technique contrasts with Palestrina's treatment of cantus firmus as described by Peter Schubert. Probably because he was unwilling to use the kind of literal repetition favored by composers around 1500, Palestrina relied on fewer modules in his cantus firmus pieces. ${ }^{45}$

The emphasis on repetition and the contrapuntal techniques described here are in no way unique to Isaac: they occur in countless pieces in the decades around $1500 .{ }^{46}$ Yet these two pieces do illustrate some techniques that are particularly common in Isaac's music. We have seen that in Inviolata and often in Alma redemptoris mater Isaac loved to write modules involving all (or almost all) the voices in the texture and to build modular sequences around long notes in one voice (for other examples of this technique, see his $O$ decus or La morra) ${ }^{47} \mathrm{He}$ was also very fond of imitation or canons derived from a cantus firmus. ${ }^{48}$

Understanding and labeling the contrapuntal techniques used in composition of this period allow us to talk about the music with a new precision and provide us with concrete ways to describe the differences between composers and genres. Only when we have a name for something can we recognize and identify it consistently. ${ }^{49}$ Having labels makes it easier to figure out how the various elements are combined into successful pieces and large-scale forms.

McGill University

45 Schubert, "Hidden Forms," 489-90, n. 16.

46 On repetition, see Cumming, "From Variety to Repetition," and Jesse Rodin, "When in Rome ... ': What Josquin Learned in the Sistine Chapel," Journal of the American Musicological Society 61 (2008): 307-72. For another look at compositional processes in the fifteenth century, see Cumming, "From Two-Part Framework to Movable Module," forthcoming.

47 For O decus, see Der Mensuralkodex des Nikolaus Apel (Ms. 1494 der Universitätsbibliothek Leipzig), ed. Rudolf Gerber, Ludwig Finscher, and Wolfgang Dömling, Das Erbe deutscher Musik 33 (Kassel: Bärenreiter, 1956-75), 2:155-62. For La morra, see One Hundred Songs of Harmonic Music, Ottaviano Petrucci, 1501, A Quincentenary Performing Edition, ed. David Fallows (Shirley, MA: Amherst Early Music, 2001), 88-89.

${ }^{48}$ Katelijne Schiltz lists all the cantus-firmus canons in the Choralis Constantinus, vol. 2 in "'Aus einem Hauptgedanken"”; and Schubert and Cumming, "Chant-Paraphrase Canon."

${ }^{49}$ In the introduction to his Music in the Galant Style (New York: Oxford University Press, 2007), 20, Robert O. Gjerdingen makes the following comment about the act of naming musical procedures. "It is, of course, possible to have musical knowledge that does not correspond to a name. The musical knowledge of ordinary listeners is of that type. But just as one can hardly imagine a serious inquiry into the characteristics and habits of different species of birds without using the names of birds, so it would be difficult to compare and contrast the species of galant musical phrases without the ability to name them." The same could be said about Renaissance music. 


\begin{abstract}
In the decades around 1500 composers learned to combine the new style of imitative polyphony with the older practice of basing a work on a cantus firmus. By applying Peter Schubert's technique of modular analysis and his descriptions of common contrapuntal techniques to Heinrich Isaac's Inviolata integra et casta es Maria and Alma redemptoris mater, we can learn a great deal about compositional process in the period. Inviolata, which features a cantus firmus in strict canon after two measures, consists of two-, three-, and four-voice modules. Moreover, understanding the modular construction of the piece makes it possible to reconstruct the missing contratenor 2 part. In Alma redemptoris mater, which features a tenor cantus firmus that uses both long-note presentation and free paraphrase, Isaac uses four-voice modules, imitative presentation types involving modules, and nonmodular contrapuntal techniques probably derived from improvisatory practices. Understanding and labeling the contrapuntal techniques used in composition of this period allow us to analyze the music with a new precision, and to describe the differences between composers and genres.
\end{abstract}

Keywords: Alma redemptoris mater, compositional process, Heinrich Isaac, Inviolata integra et casta es Maria, module, Renaissance counterpoint 
THE JOURNAL OF MUSICOLOGY

\section{Appendix I}

Isaac, Inviolata integra et casta es Maria, with markings and contratenor 2 (composed by Julie E. Cumming). Motetti a cinque (Venice, 1508), no. 7
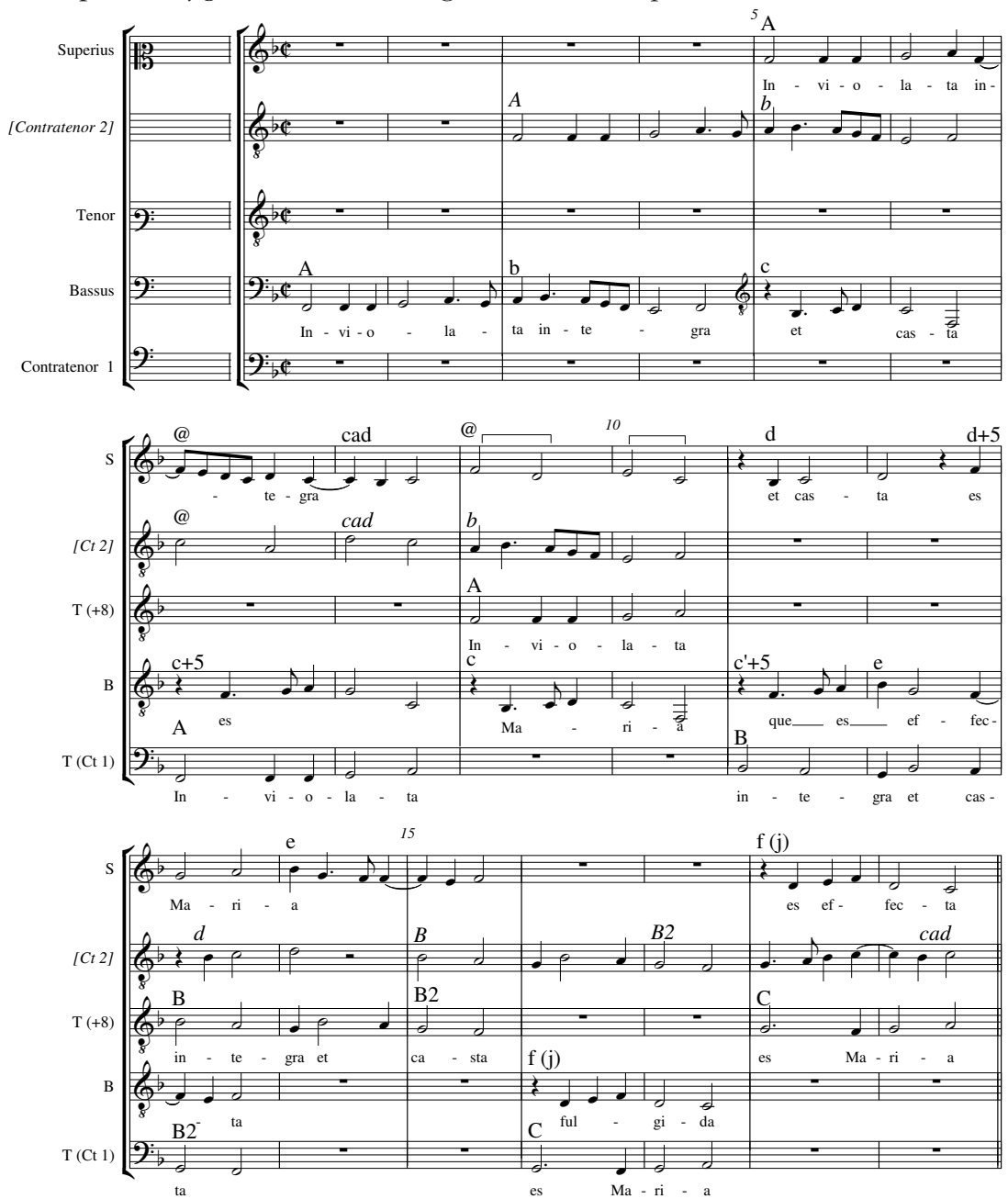
Appendix I (continued)
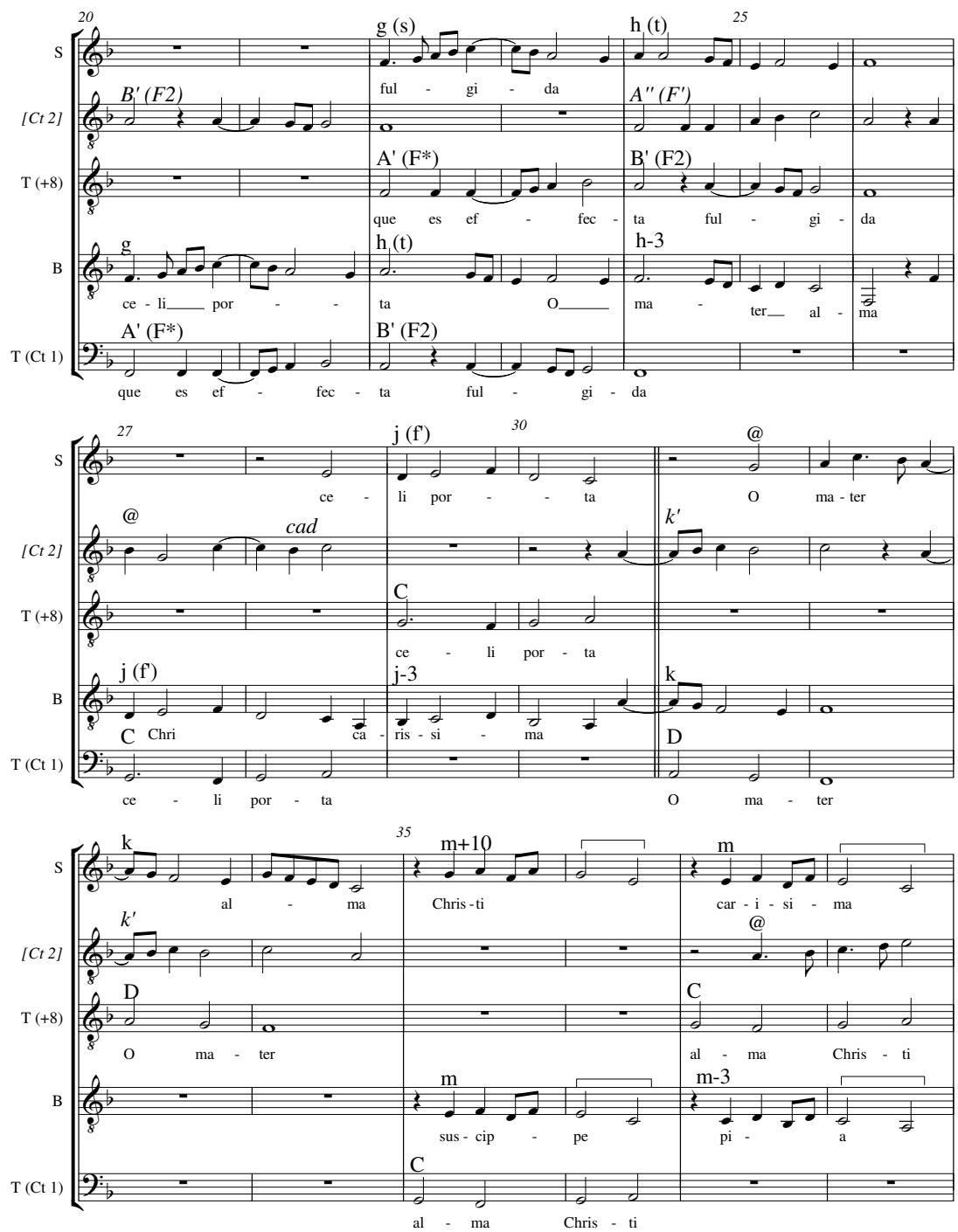
THE JOURNAL OF MUSICOLOGY

Appendix I (continued)
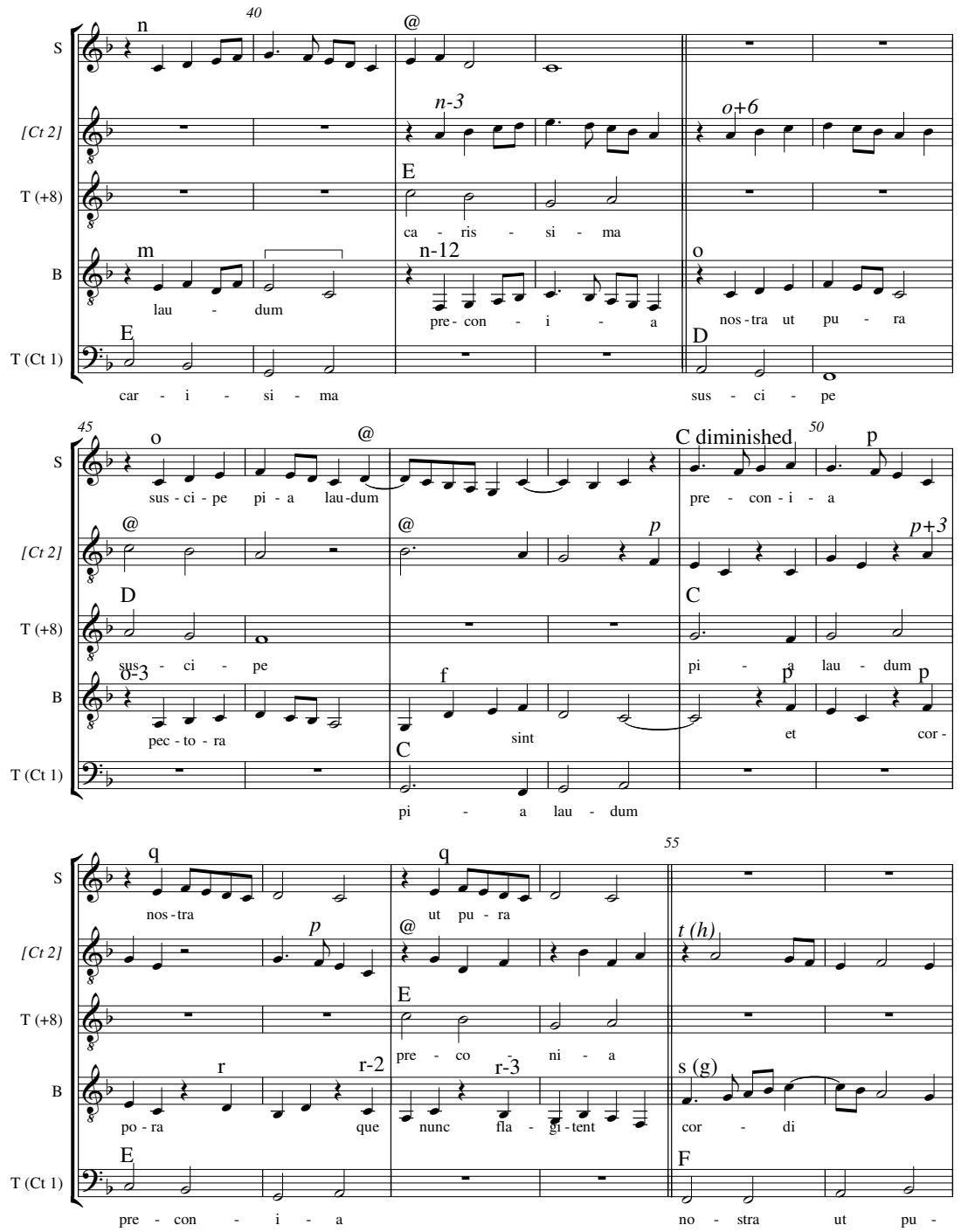
Appendix I (continued)
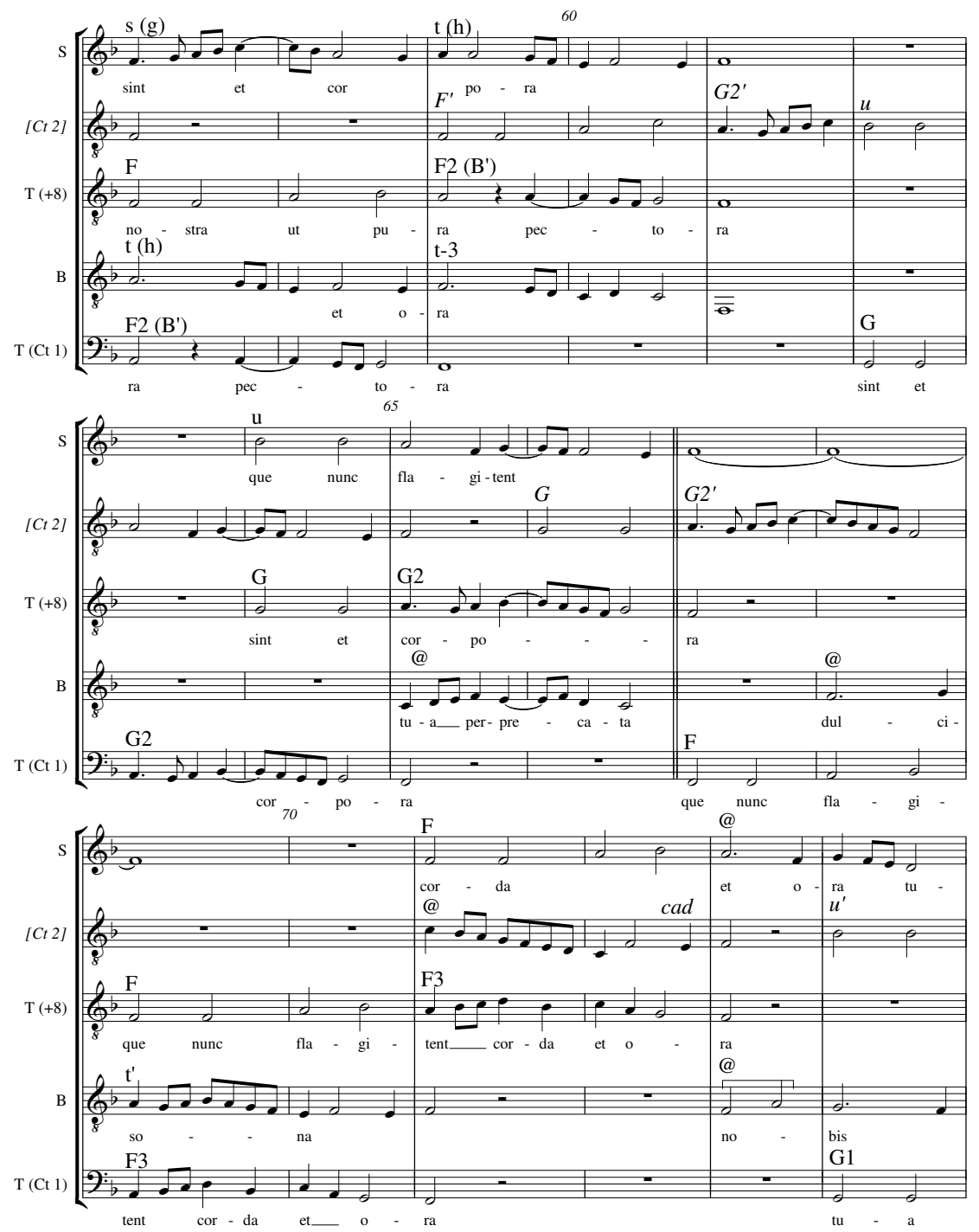
THE JOURNAL OF MUSICOLOGY

Appendix I (continued)

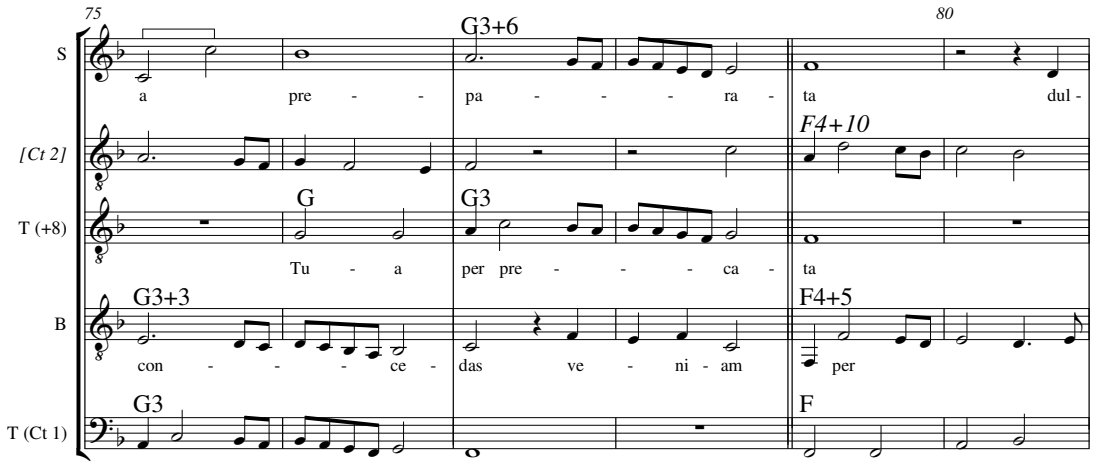
pre - pa - ra - ta

${ }_{85} \mathrm{dul}-\mathrm{cis}$
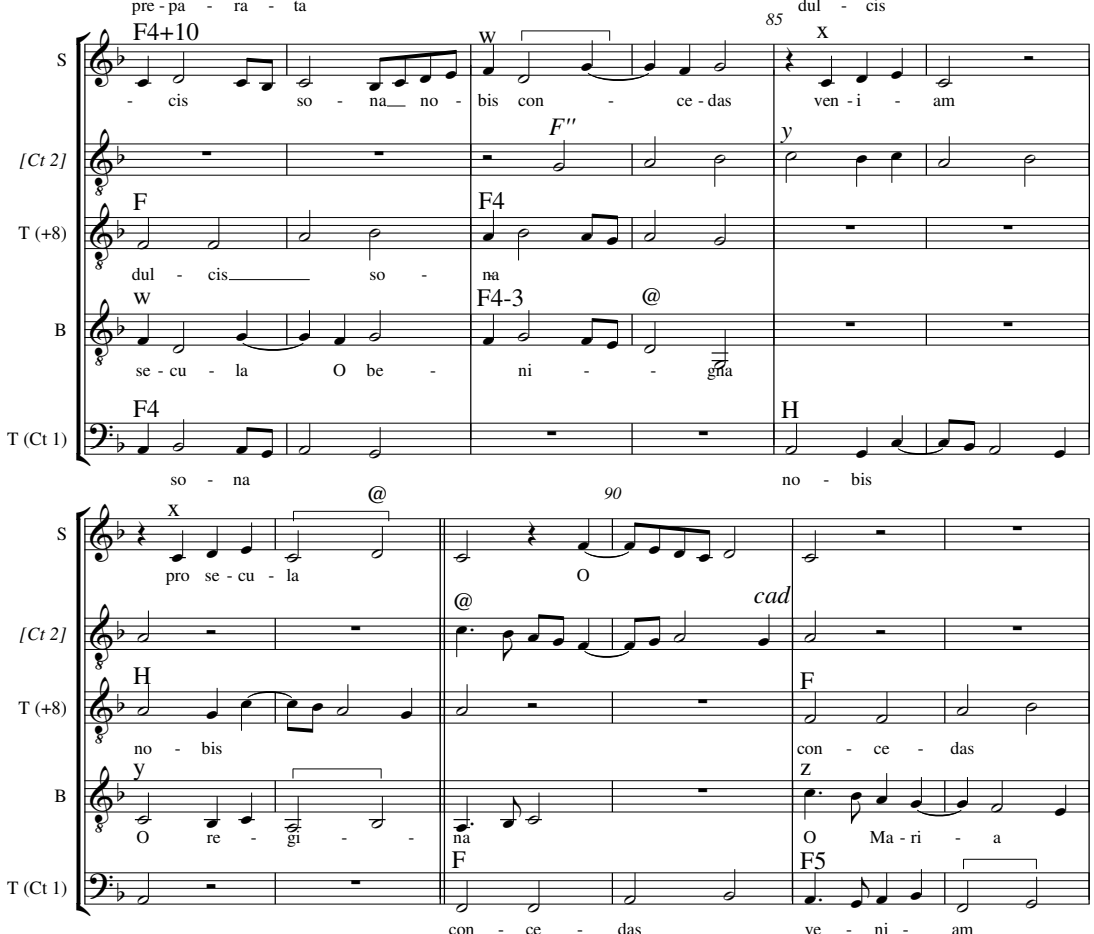
Appendix I (continued)
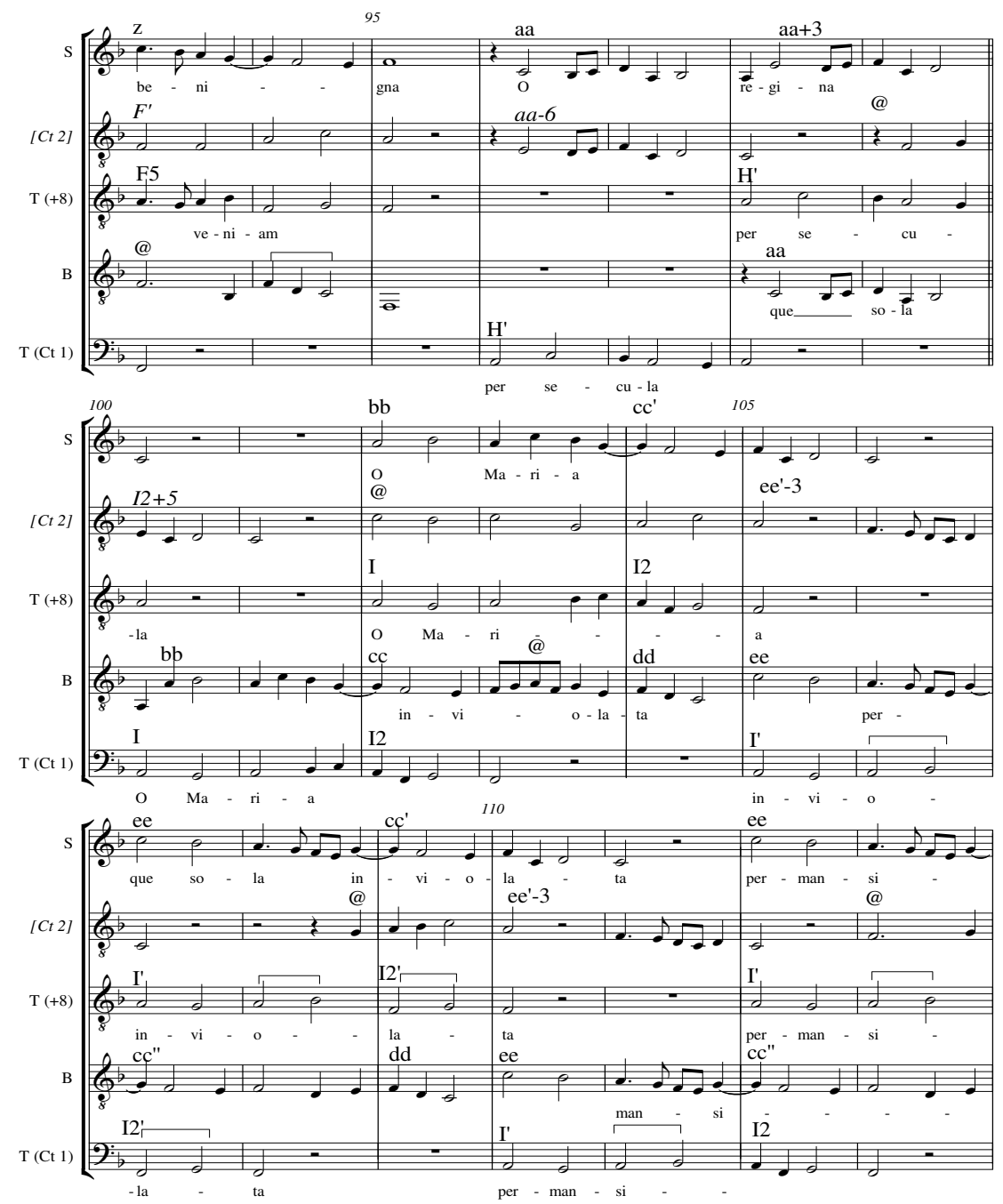


\section{Appendix I (continued)}

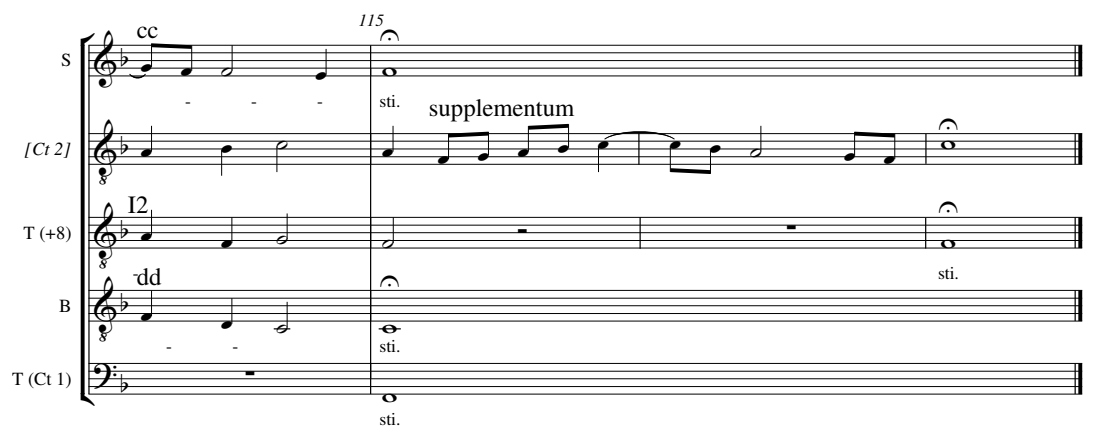

\section{Appendix II}

Complete diagram of Isaac, Inviolata integra et casta es Maria with added contratenor 2

\begin{tabular}{|c|c|c|c|c|c|c|c|c|c|c|}
\hline Mm. & $1-2$ & $3-4$ & $5-6$ & $7-8$ & $9-10$ & $11-12$ & $13-14$ & 15 & $16-17$ & $18-19$ \\
\hline Text & \multicolumn{5}{|c|}{ Inviolata } & \multicolumn{3}{|c|}{ integra et casta } & \multicolumn{2}{|c|}{ es Maria } \\
\hline S & & & $\mathrm{A}$ & $@$ & $@$ & $\bar{d}$ & $d+5 \mathrm{e}$ & $>$ & & $f(j)$ \\
\hline [Ct 2] & & $A$ & $b$ & @ cad & $b$ & & $d$ & & $>B 2$ & $c a d$ \\
\hline $\mathrm{T}(+8)$ & & & & & $\mathbf{A}$ & & B & B2 & & C \\
\hline B & A & $\mathrm{b}$ & $\mathrm{c}$ & $c+5$ & $\mathrm{c}$ & $c^{\prime}+5 e$ & $>$ & & $f(j)$ & \\
\hline $\mathrm{T}(\mathrm{Ct} 1)$ & & & & $\mathbf{A}$ & & B & B2 & & C & \\
\hline $\mathrm{Mm}$. & & 20-21 & & 22-23 & & & 26 & & 27-28 & $29-30$ \\
\hline Text & \multicolumn{7}{|c|}{ Quae es effecta fulgida } & & \multicolumn{2}{|c|}{ celi porta } \\
\hline $\mathrm{S}$ & & & & $\mathrm{g}(\mathrm{s})$ & & & $>$ & & & $j\left(f^{\prime}\right)$ \\
\hline [Ct 2] & & $B^{\prime}(F 2)$ & & $>$ & & & $>$ & & @ cad & \\
\hline $\mathrm{T}(+8)$ & & & & $\mathbf{A}^{\prime}\left(\mathbf{F}^{*}\right)$ & & & $>$ & & & C \\
\hline B & & $g(s)$ & & $\mathrm{h}(\mathrm{t})$ & & & $@$ & & $j\left(f^{\prime}\right)$ & $\mathrm{j}-3$ \\
\hline $\mathrm{T}(\mathrm{Ct} 1)$ & & $\mathbf{A}^{\prime}\left(\mathbf{F}^{*}\right)$ & & $\mathbf{B}^{\prime}(\mathrm{F} 2)$ & $>$ & & & & C & \\
\hline
\end{tabular}


Appendix II (continued)

\begin{tabular}{|c|c|c|c|c|c|c|}
\hline Mm. & $31-32$ & $33-34$ & $35-36$ & $37-38$ & $39-40$ & $41-42$ \\
\hline Text & \multicolumn{2}{|c|}{ O mater } & \multicolumn{2}{|c|}{ alma Christi } & \multicolumn{2}{|c|}{ carissima } \\
\hline S & $\bar{@}$ & $\mathrm{k}$ & $\overline{m+10}$ & $\mathrm{~m}$ & $\overline{\mathrm{n}}$ & $\mathrm{m}^{\prime}$ \\
\hline [Ct 2] & $k^{\prime}$ & $k^{\prime}$ & & $@$ & & $n-3$ \\
\hline $\mathrm{T}(+8)$ & & D & & C & & $\mathbf{E}$ \\
\hline B & $\mathrm{k}$ & & $\mathrm{m}$ & $m-3$ & $\mathrm{~m}$ & $\mathrm{n}-12$ \\
\hline $\mathrm{T}(\mathrm{Ct} 1)$ & $\mathbf{D}$ & & C & & $\mathbf{E}$ & \\
\hline Mm. & $43-44$ & $45-46$ & $47-48$ & $49-50$ & $51-52$ & $53-54$ \\
\hline Text & \multicolumn{2}{|c|}{ Suscipe } & \multicolumn{2}{|c|}{ pia laudum } & \multicolumn{2}{|c|}{ preconia } \\
\hline $\mathrm{S}$ & & o & $\overline{(a)}$ & $\overline{c \operatorname{dim} p}$ & $\bar{q}$ & $q$ \\
\hline [Ct 2] & $\mathrm{o}+6$ & @ & @ & $p$ & $p+3 p$ & @ \\
\hline $\mathrm{T}(+8)$ & & D & & C & & $\mathbf{E}$ \\
\hline B & o & o-3 & $\mathrm{f}$ & $\mathrm{p}$ & $\mathrm{pr}$ & $r-2 r-3$ \\
\hline $\mathrm{T}(\mathrm{Ct} 1)$ & D & & C & & $\mathbf{E}$ & \\
\hline
\end{tabular}

\begin{tabular}{|c|c|c|c|c|c|c|c|}
\hline $\mathrm{Mm}$. & $55-56$ & $57-58$ & $59-60$ & 61 & 62 & $63-64$ & $65-66$ \\
\hline Text & \multicolumn{4}{|c|}{ Nostra ut pura } & \multicolumn{3}{|c|}{ sint et corpora } \\
\hline $\mathrm{S}$ & & $\mathrm{s}(\mathrm{g})$ & $\mathrm{t}(\mathrm{h})$ & $>$ & & $\mathrm{u}$ & $>>$ \\
\hline [Ct 2] & $t(h)$ & & $F^{\prime}$ & $G 2^{\prime}$ & $u$ & $>$ & $>G$ \\
\hline $\mathrm{T}(+8)$ & & $\mathbf{F}$ & F2(B') & $>$ & & G & G2 \\
\hline B & $\mathrm{s}(\mathrm{g})$ & $\mathrm{t}(\mathrm{h})$ & $t^{\prime}-3$ & $>$ & & $@$ & $@$ \\
\hline $\mathrm{T}(\mathrm{Ct} 1)$ & $\mathbf{F}$ & F2(B') & $>$ & & G & G2 & $>$ \\
\hline
\end{tabular}

\begin{tabular}{|c|c|c|c|c|c|c|c|}
\hline $\mathrm{Mm}$. & $67-68$ & $69-70$ & $71-72$ & 73 & 74 & $75-76$ & $77-78$ \\
\hline Text & \multicolumn{4}{|c|}{ Que nunc flagitant corda et ora } & \multicolumn{3}{|c|}{ Tua per precata } \\
\hline S & $>$ & & $\mathrm{F}$ & @ & $\bar{@}$ & @ & G3+6 \\
\hline [Ct 2] & $G 2^{\prime}$ & & @ cad & $>$ & $u^{\prime}$ & $>c a d$ & \\
\hline $\mathrm{T}(+8)$ & $>$ & $\mathbf{F}$ & F3 & $>$ & & $\mathbf{G}$ & G3 \\
\hline $\mathrm{B}$ & @ & $\mathrm{t}^{\prime}$ & $>$ & $@$ & $@$ & G3+3 & $>@$ \\
\hline $\mathrm{T}(\mathrm{Ct} 1)$ & $\mathbf{F}$ & F3 & $>$ & & $\mathbf{G}$ & G3 & $>$ \\
\hline
\end{tabular}


THE JOURNAL OF MUSICOLOGY

Appendix II (continued)

\begin{tabular}{|c|c|c|c|c|c|}
\hline Mm. & $79-80$ & $81-82$ & $83-84$ & $85-86$ & $87-88$ \\
\hline Text & \multicolumn{3}{|c|}{ dulcis sona } & \multicolumn{2}{|c|}{ Nobis } \\
\hline S & $>$ & $\mathrm{F} 4+10$ & $\mathrm{w}$ & $\bar{x}$ & $\mathrm{x}$ \\
\hline [Ct 2] & $\mathrm{F} 4+10$ & & $F^{\prime \prime}$ & $y$ & \\
\hline $\mathrm{T}(+8)$ & $>$ & $\mathbf{F}$ & F4 & & $\mathbf{H}$ \\
\hline B & $\mathrm{F} 4+5$ & $\mathrm{w}$ & $\mathrm{F} 4+6$ & & $\mathrm{y}$ \\
\hline $\mathrm{T}(\mathrm{Ct} 1)$ & $\mathbf{F}$ & F4 & & $\mathbf{H}$ & $>$ \\
\hline
\end{tabular}

\begin{tabular}{|c|c|c|c|c|c|c|}
\hline Mm. & $89-90$ & $91-92$ & $93-94$ & 95 & $96-97$ & 98-99 \\
\hline Text & \multicolumn{4}{|c|}{ concedas veniam } & \multicolumn{2}{|c|}{ per secula } \\
\hline $\mathrm{S}$ & @ & & $\mathrm{z}$ & $>$ & $\overline{\mathrm{aa}}$ & $\mathrm{aa}+3$ \\
\hline [Ct 2] & $@_{c a d}$ & & $F^{\prime}$ & $>$ & $a a-6$ & @ \\
\hline $\mathrm{T}(+8)$ & $>$ & $\mathbf{F}$ & F5 & $>$ & & $\mathbf{H}^{\prime}$ \\
\hline B & $>$ & $\mathrm{z}$ & $>@$ & @ & & aa \\
\hline $\mathrm{T}(\mathrm{Ct} 1)$ & $\mathbf{F}$ & F5 & $>$ & & $\mathbf{H}^{\prime}$ & \\
\hline
\end{tabular}

\begin{tabular}{|c|c|c|c|c|c|c|c|c|c|c|}
\hline Mm. & $100-$ & $102-$ & 104 & 105 & 107 & 109 & 110 & 112 & 114 & $115-117$ \\
\hline Text & & Mar & & & viola & & & nan & & supplementum \\
\hline $\mathrm{S}$ & $>$ & $\mathrm{bb}$ & $\mathrm{cc}^{\prime}$ & $>$ & ee & $\mathrm{cc}^{\prime}$ & $>$ & ee & $\mathrm{cc}$ & $>$ \\
\hline [Ct 2] & $12+5$ & @ & & $e e^{\prime}-3$ & & @ & $e e-3$ & & @ & @ \\
\hline $\mathrm{T}(+8)$ & $>$ & I & I2 & $>$ & $\mathbf{I}^{\prime}$ & I2' & $>$ & $\mathbf{I}^{\prime}$ & I2 & $>$ \\
\hline B & $\mathrm{bb}$ & cc@ & $\mathrm{dd}$ & ee & cc" & $\mathrm{dd}$ & ee & cc" & $\mathrm{dd}$ & $>$ \\
\hline $\mathrm{T}(\mathrm{Ct} 1)$ & I & I2 & & $\mathbf{I}^{\prime}$ & I2' & & $\mathbf{I}^{\prime}$ & I2 & & $>$ \\
\hline
\end{tabular}




\section{Key to Appendix II}

Diagram of Inviolata integra et casta

Mm: Measures.

Text: Text of the two cantus-firmus voices (and of the other voices, except at the end, mm. 100-117, where the other voices have more text) according to underlay in Petrucci's Motetti a cinque.

S, [Ct 2], $\mathbf{T}(+8), \mathbf{B}$, and $\mathbf{T}(\mathbf{C t} \mathbf{1})$ : Voice labels in Motetti a cinque. The Contratenor 2 partbook is missing, which is why the voice label is in square brackets, and the letters are in italics, indicating that they are not in the surviving sources.

Capital letters in boldface are labels for the different melodies in the cantus firmus. The $d u x$ is in the bass register. It is found in the Contratenor 1 partbook, and therefore labeled $\mathbf{T}(\mathbf{C t} \mathbf{1})$. The comes is heard at the octave above after two measures. It is found in the Tenor partbook, and therefore labeled $\mathbf{T}(+8)$.

Capital letters followed by numbers: Where the cantus-firmus melodies overlap, the second portion or continuation is identified by the initial letter followed by a number. For example, several phrases begin with melody F; F's continuations are F2, F3, F4, and F5.

lowercase letters: repeated melodies in voices other than the cantus firmus.

Letters followed by an apostrophe or an asterisk are varied repetitions of the original melody. A double apostrophe indicates a different variation of the original melody.

Letters followed by another letter in parentheses indicate that the tune is also found with that label elsewhere in the piece. $\mathbf{B}^{\prime}(\mathbf{F} 2)$ indicates that the varied form of $\mathbf{B}$ found in $\mathrm{mm} .22-26$ is the same as F2 (a continuation of $\mathrm{F}$ ) in $\mathrm{mm}$. 57-61. The marking " $\mathrm{g}(\mathrm{s})$ " indicates that melody "g" is the same as melody "s," found later in the piece. $\mathbf{A}^{\prime}\left(\mathbf{F}^{*}\right)$ indicates that the varied form of $\mathbf{A}$ found in $\mathrm{mm}$. 20-23 is also an embellished form of $\mathbf{F}$.

>: When a repeated melody extends into the next measure by one note, it is shown by an arrow.

@: indicates free material that is not repeated in any voice.

+5; -3: indicates transposition of a melody. Octave transposition is not shown. 
THE JOURNAL OF MUSICOLOGY

\section{Appendix III}

Isaac, Alma redemptoris mater. Motetti $C$ (Venice, 1504), no. 18.
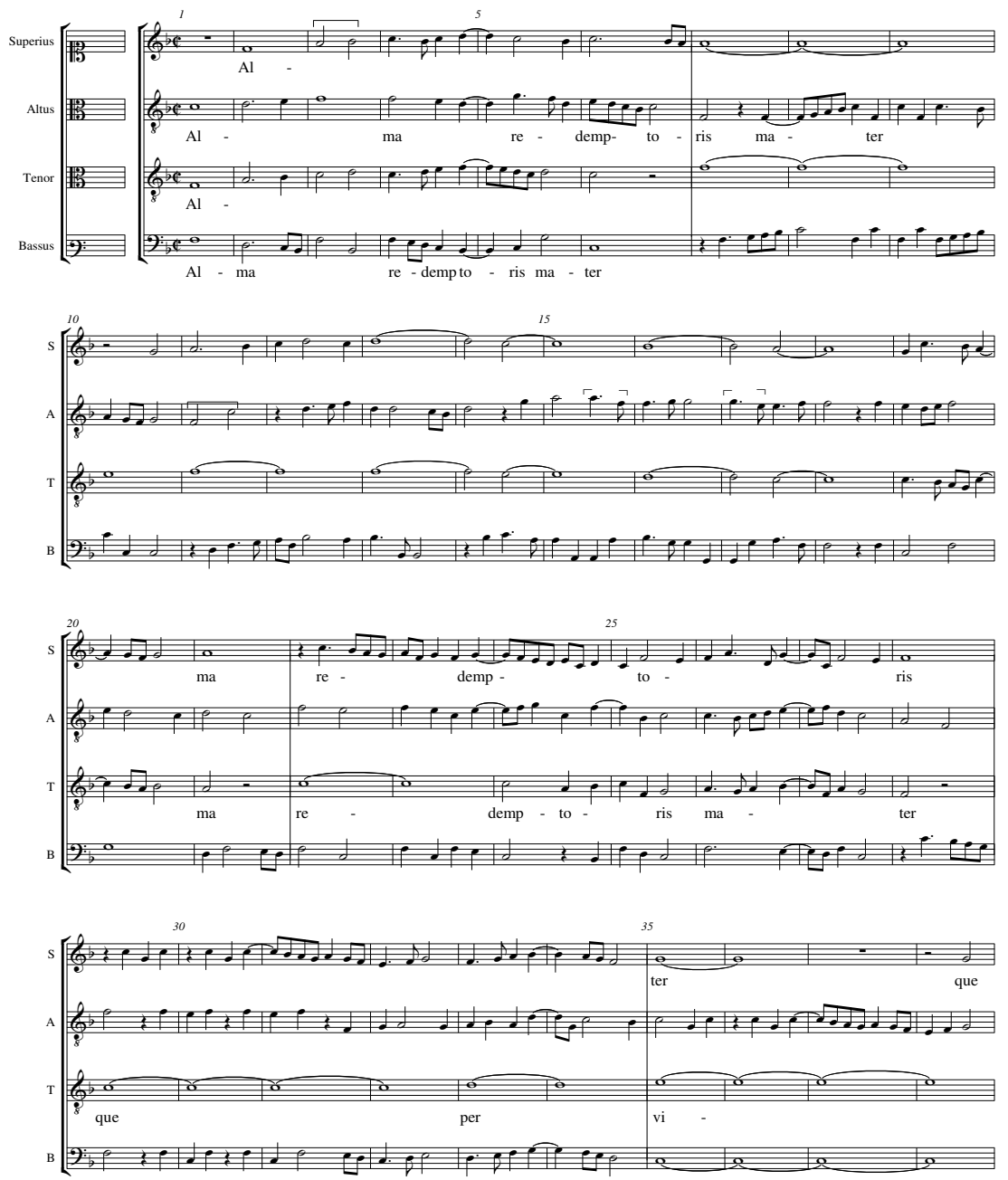
Appendix III (continued)
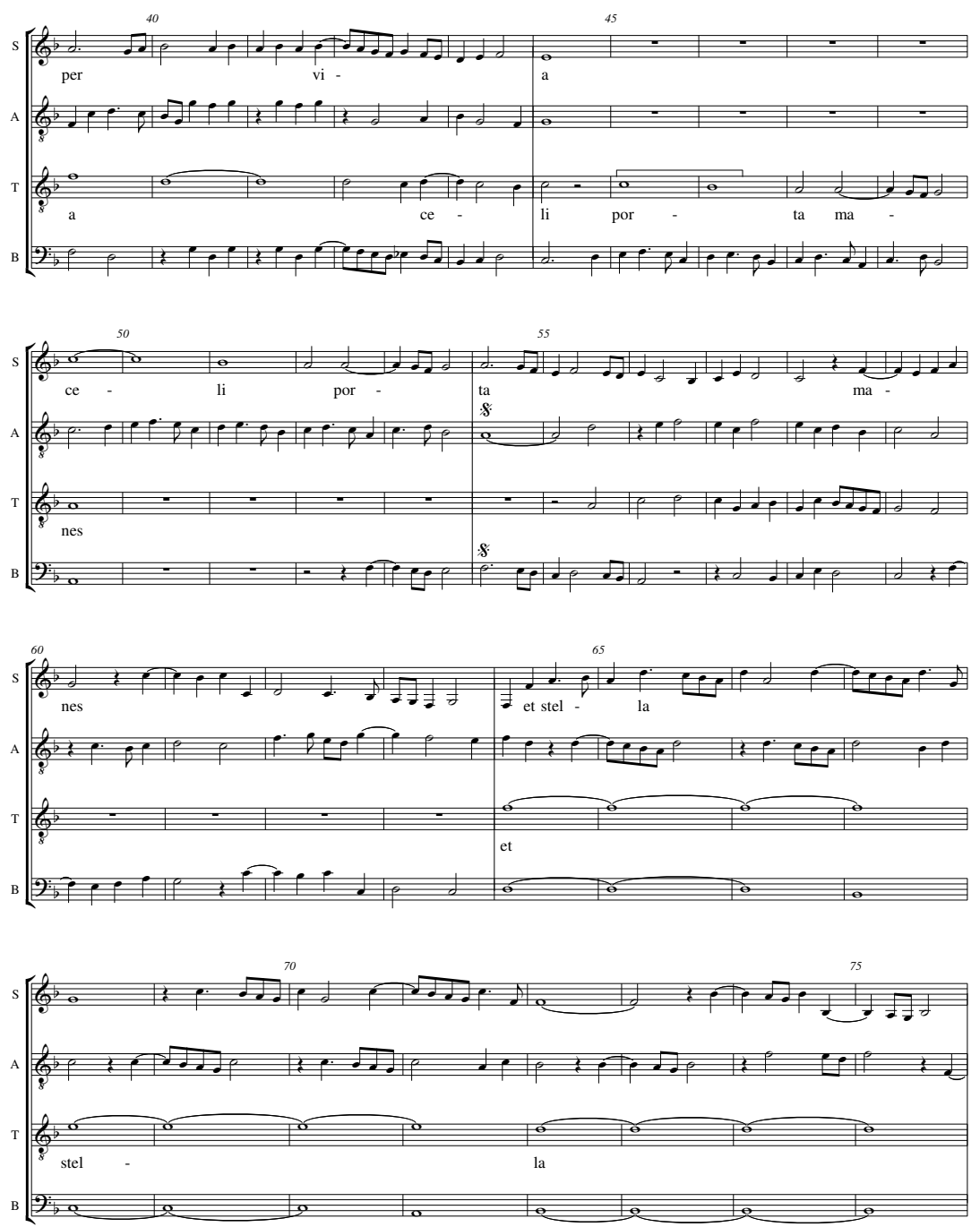
THE JOURNAL OF MUSICOLOGY

\section{Appendix III (continued)}
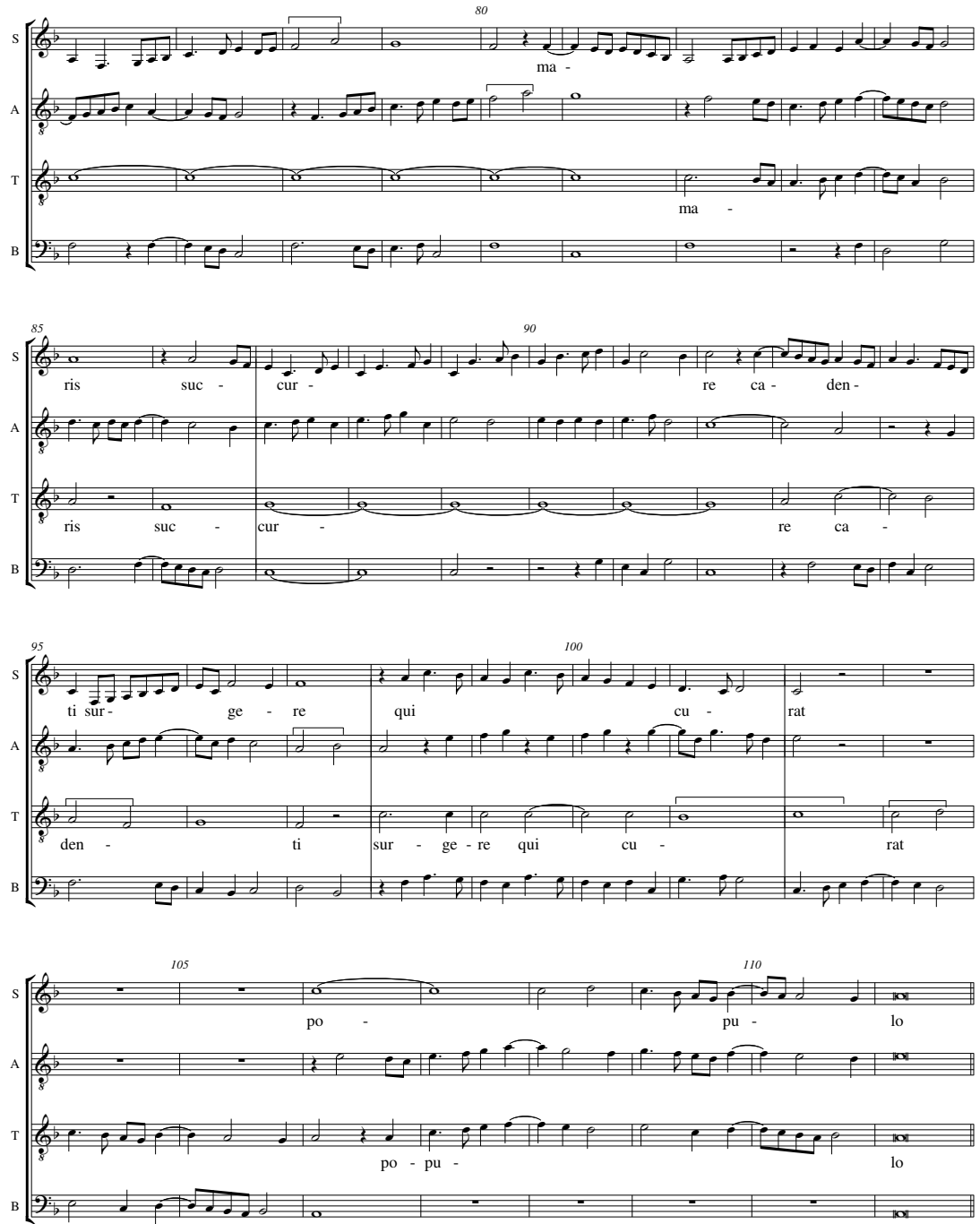


\section{Appendix III (continued)}
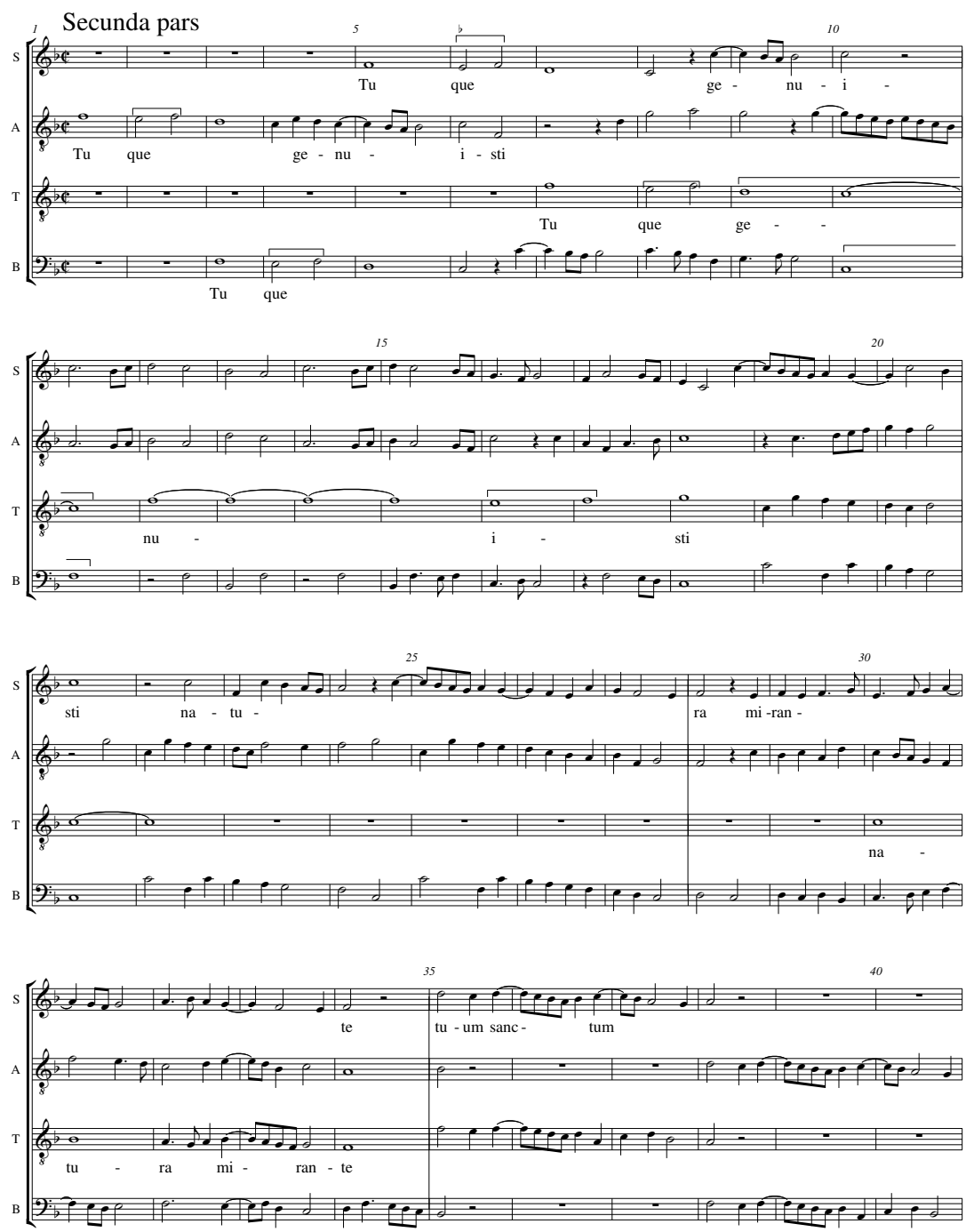
THE JOURNAL OF MUSICOLOGY

Appendix III (continued)
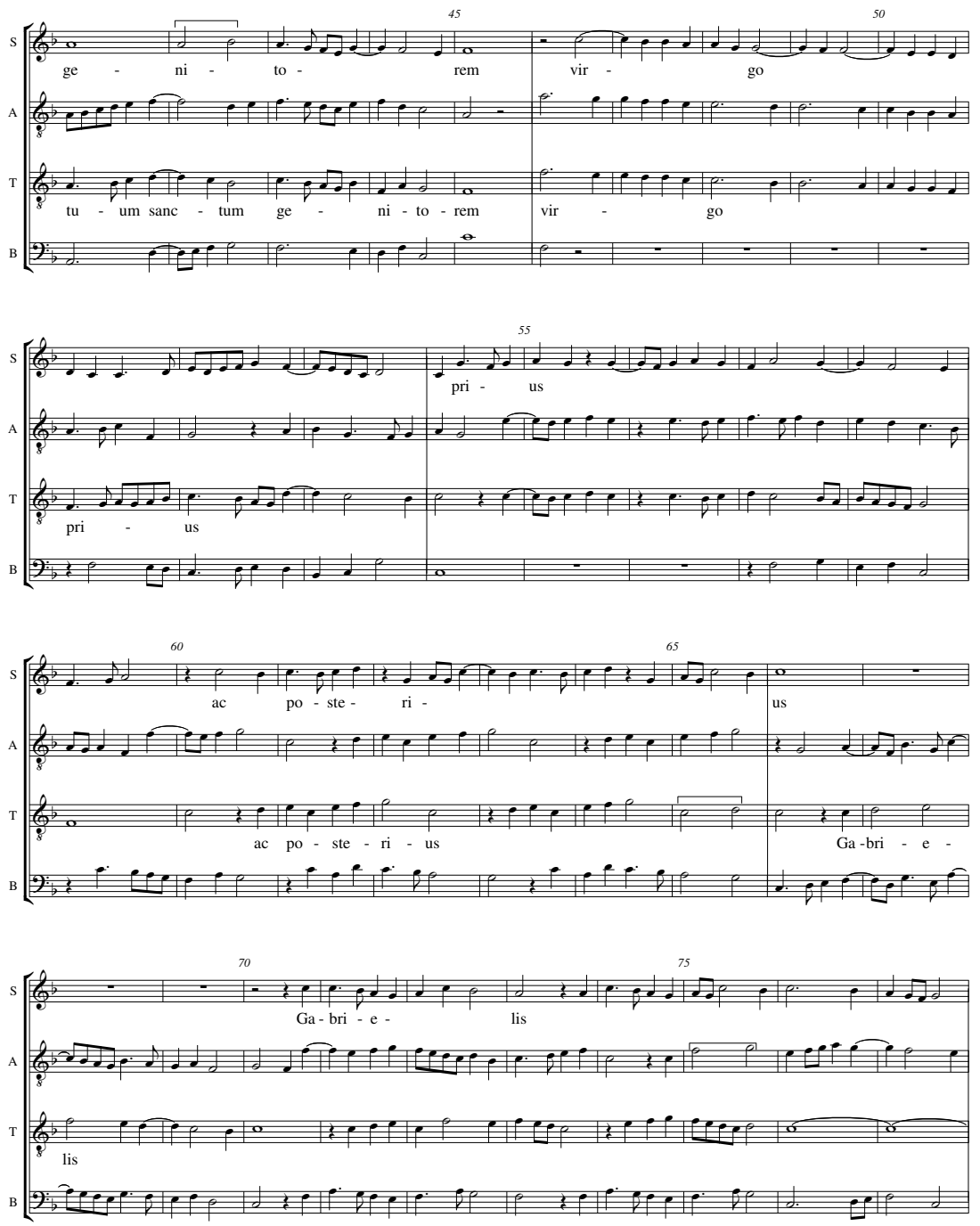


\section{Appendix III (continued)}
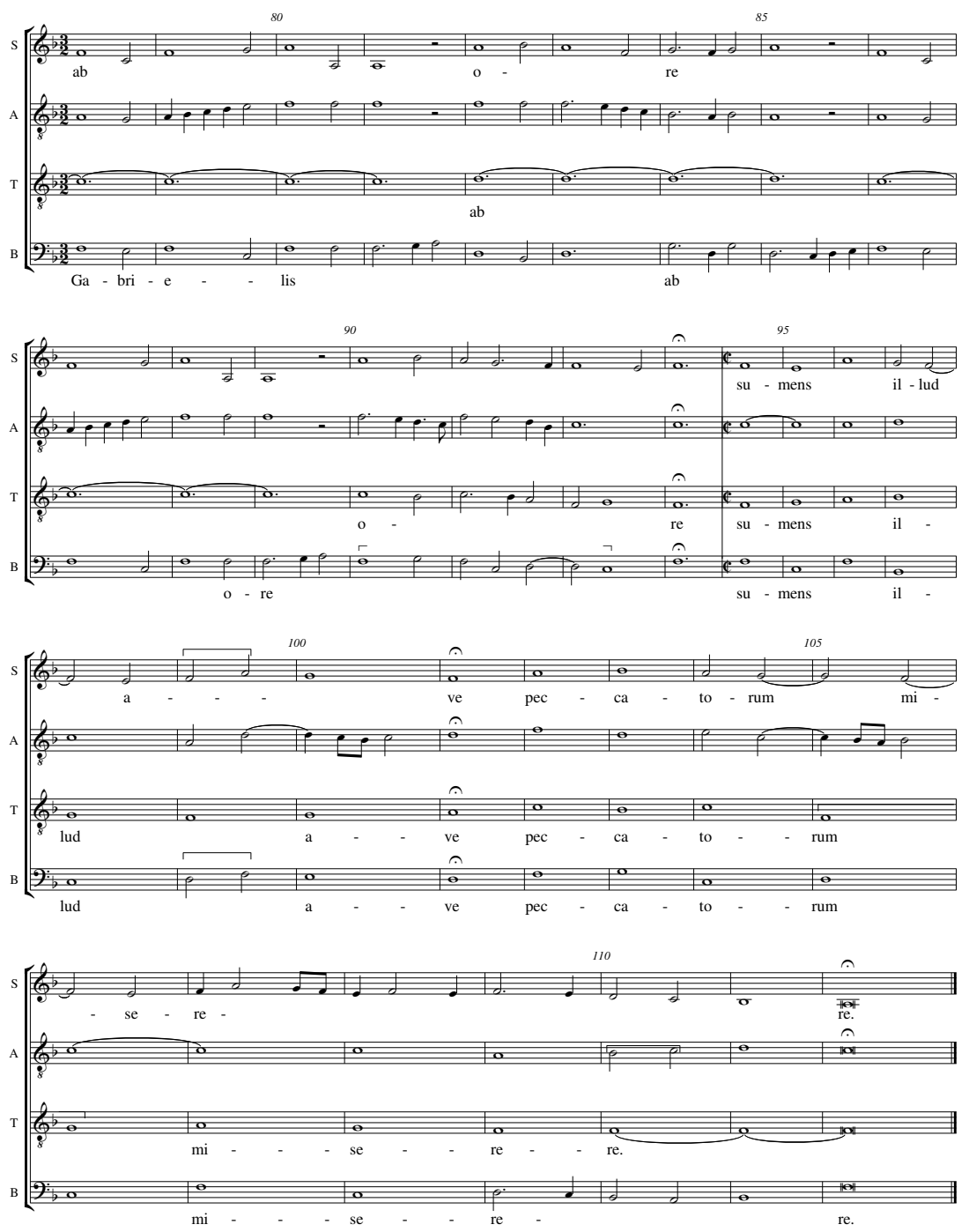
THE JOURNAL OF MUSICOLOGY

\section{Appendix IV}

Complete diagram of Isaac, Alma redemptoris mater

Prima pars

\begin{tabular}{lllllll}
\hline Cpt tech & FI-2 $>$ p6 $>$ & & cad $C$ \\
T tr & par & & & & \\
Text & Al- & & & & \\
\cline { 2 - 7 } Mm. & 1 & 2 & 3 & 4 & 5 & 6 \\
\hline
\end{tabular}

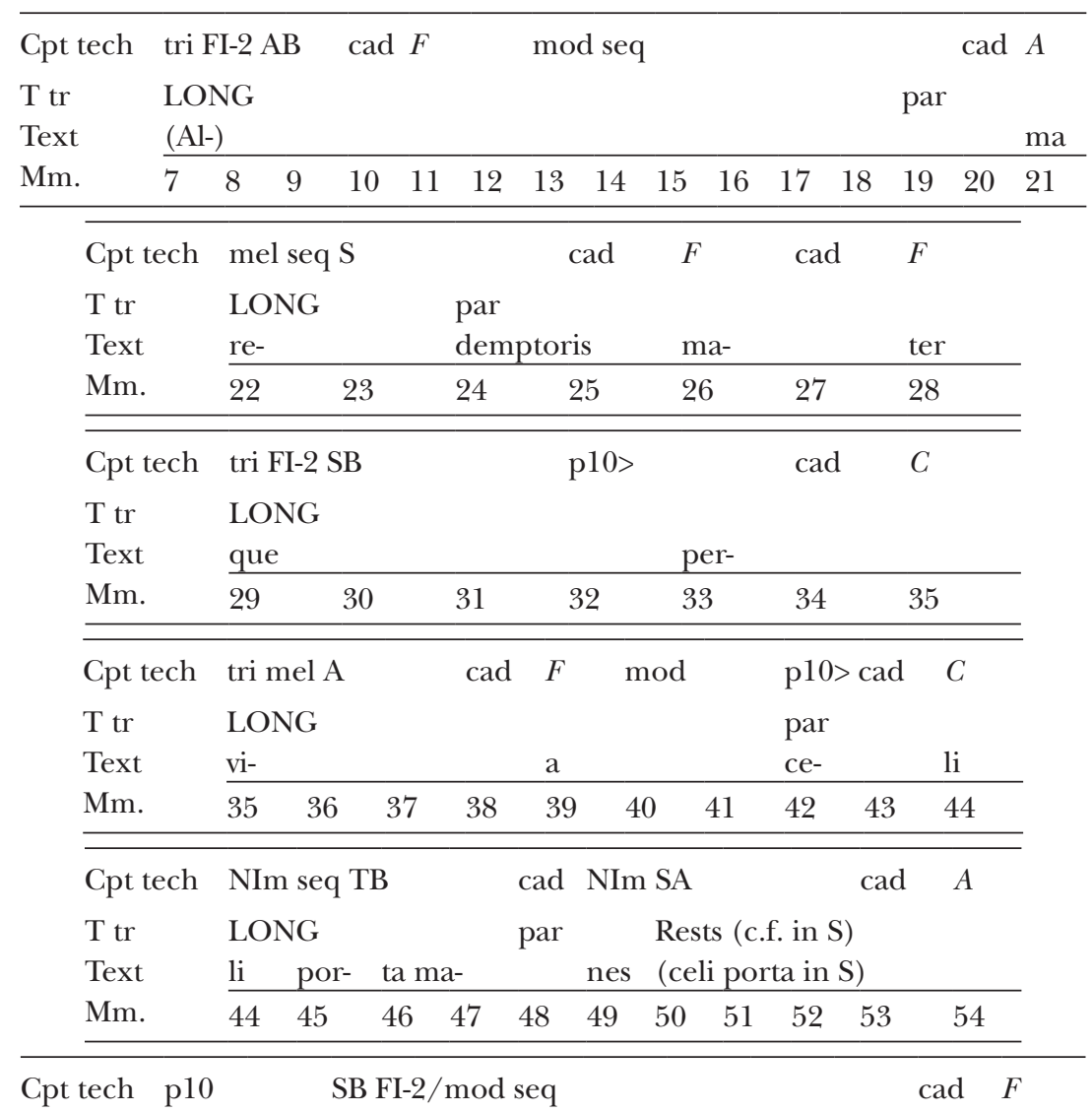

$\mathrm{T}$ tr Rest par Rests

\begin{tabular}{llllllllllll} 
Text & \multicolumn{9}{l}{ (-nes) } \\
\cline { 2 - 7 } Mm. & 54 & 55 & 56 & 57 & 58 & 59 & 60 & 61 & 62 & 63 & 64 \\
\hline
\end{tabular}

Cpt tech tri FI-2 SA, mod seq (varied 3rd time)

$\mathrm{T}$ tr $\quad$ LONG

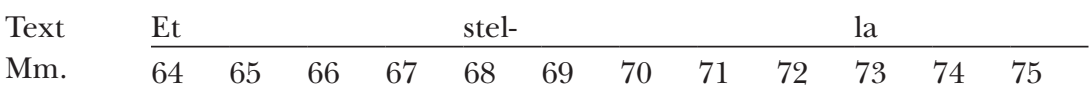


Appendix IV (continued)

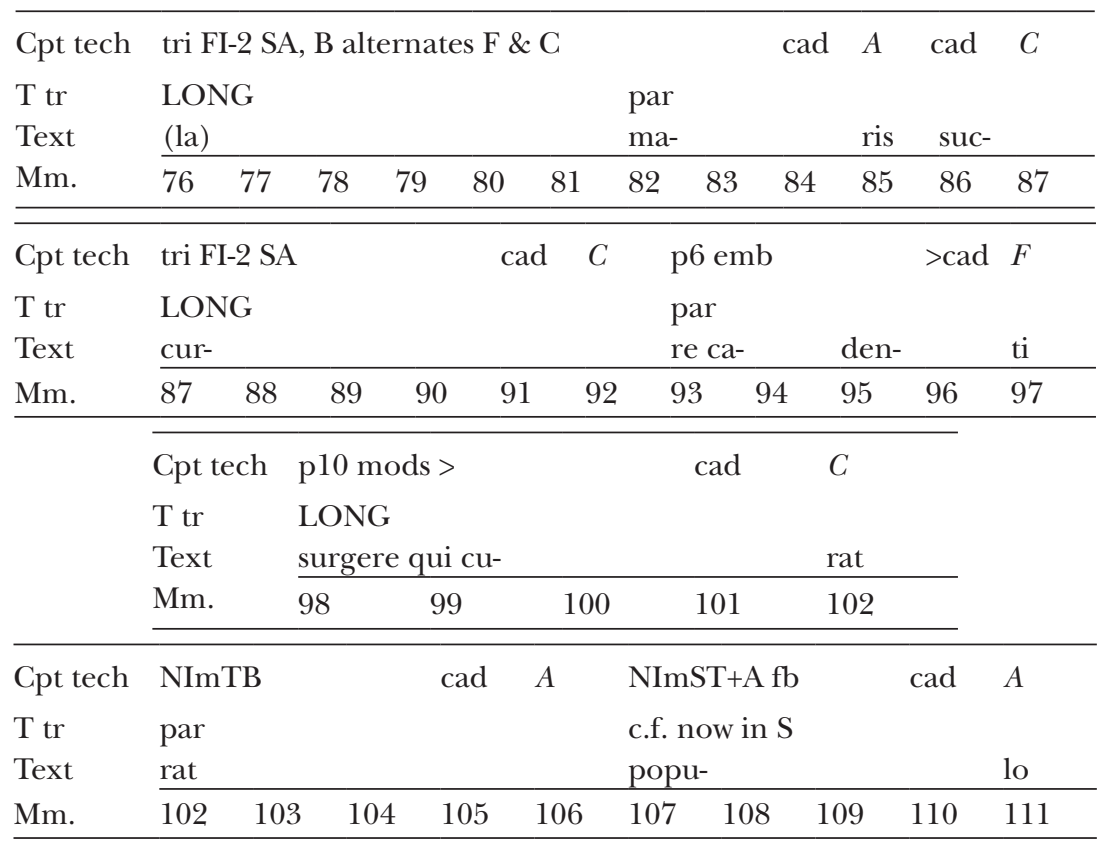

\section{Secunda pars}

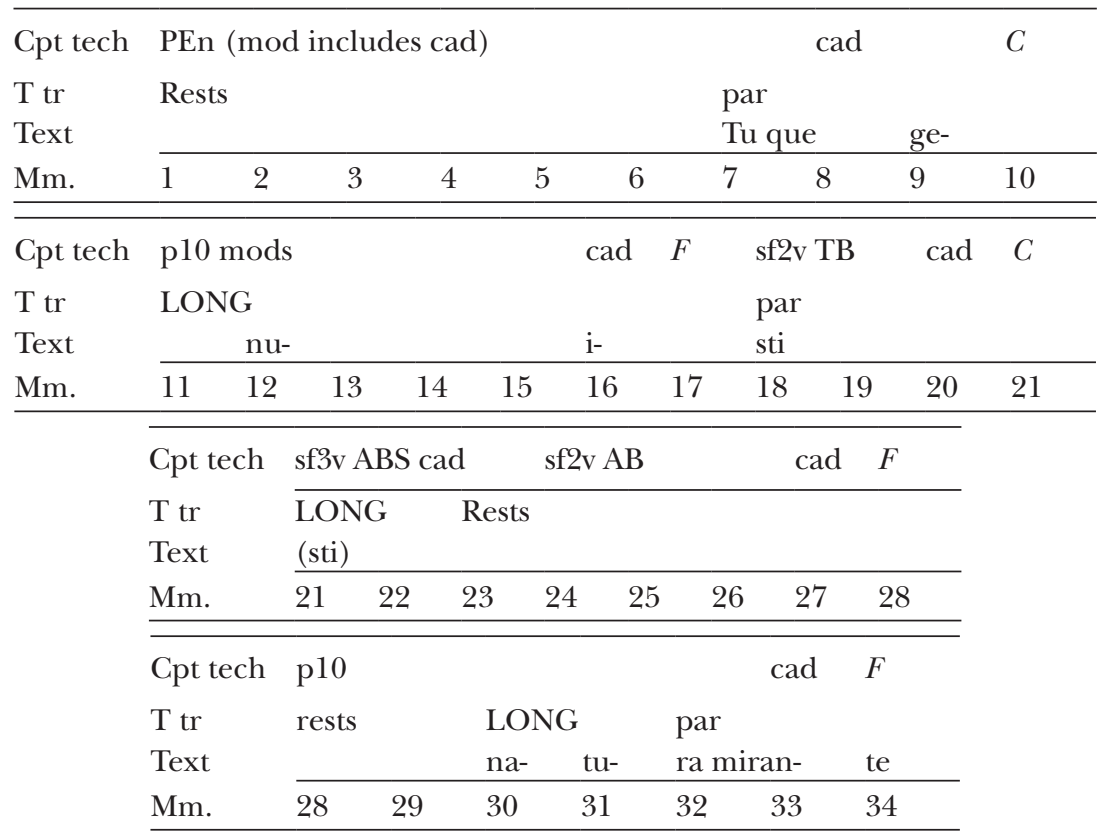


THE JOURNAL OF MUSICOLOGY

\section{Appendix IV (continued)}

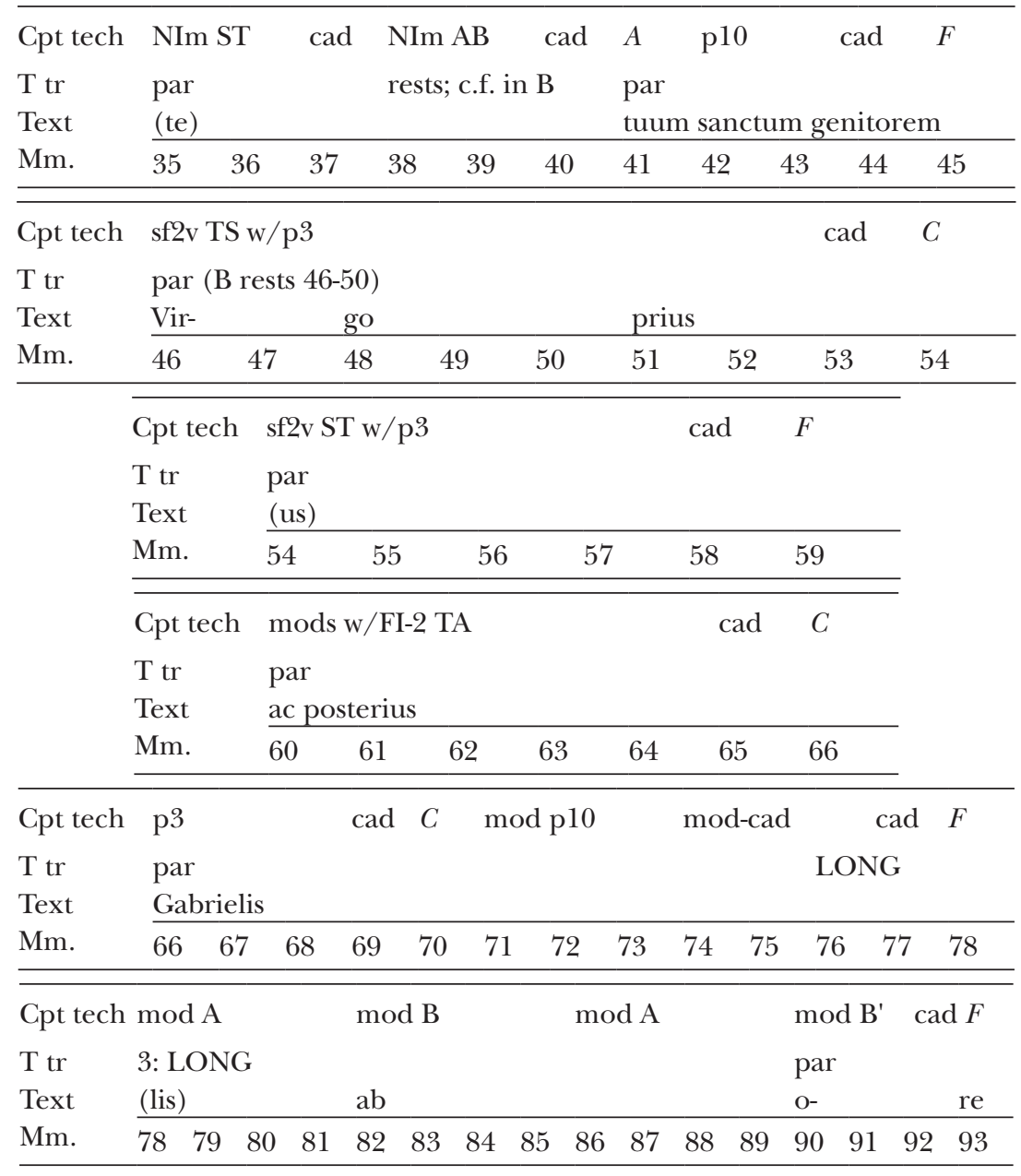

Cpt

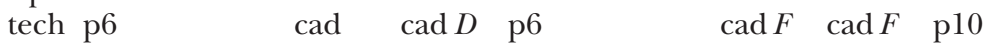

$\mathrm{T}$ tr 2: LONG (Breves, first species) LONG (Breves) supplementum

Text su- mens il- lud a- ve pec- ca- to- rum mi- se-re- re Mm. $949596979899 \quad 100101102103104105106107108109110111112$ 


\section{Key to Appendix IV}

Diagram of Alma redemptoris mater

Excerpt from diagram of Alma redemptoris mater, 2a pars, mm. 60-66

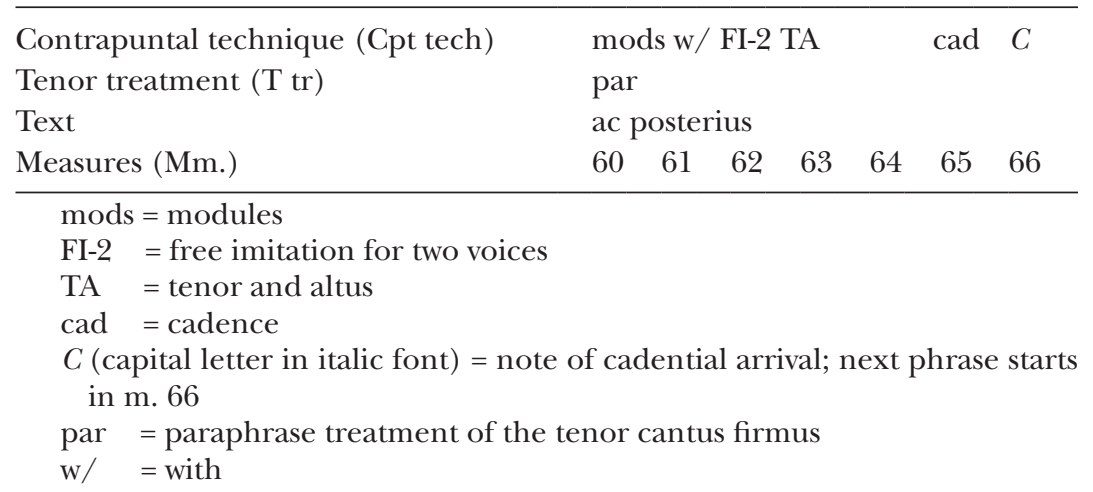

Bar lines in score: Each line in the diagram, Appendix IV, corresponds to one phrase of Alma redemptoris mater. Bar lines that extend through the whole system in the score, Appendix III, correspond to the ends of the phrases in the diagram.

Abbreviations (listed in alphabetical order):

cad: cadence. All the cadences use the stepwise sixth-to-octave progression in two voices.

The capital letter in italic font following "cad" (as in m. 21) indicates the pitch of the cadence. Some phrases pause on the cadential arrival, and begin the next phrase in the following measure (as in the first phrase, mm. 1-6). Other phrases are elided, and the new phrase begins at the cadential arrival (as in the fourth phrase of the prima pars, mm. 29-35; m. 35 is repeated at the beginning of the fifth phrase).

Cpt tech: contrapuntal techniques or presentation type.

fb: fauxbourdon. This is a subset of the parallel sixth model, with the middle voice in parallel fourths with the superius.

FI-2: Free Imitation (without a repeated module) in two voices. FI-2 can occur on its own, or it can be contained within a repeated module (FI-2/mod). Subtypes tend to occur in relation to different types of $\mathrm{T}$ treatment (see below): tri im with long notes, sf with par or rests.

LONG: a series of notes in the Tenor with the value of a breve or longer. mel seq: melodic sequence in one voice: repetition of a single melody at a different pitch level. 
mm: measures.

mod (or mods): module(s). A module is a repeated contrapuntal combination of two or more voices.

mod seq: the repetition of the module is transposed. When a module is transposed (normally up or down a second), it becomes a type of harmonic sequence, therefore it is called "mod seq."

NIm: a Non-Imitative module, normally for two voices, that is repeated in a different pair of voices (so this term will always appear in pairs); this is a standard presentation type for imitative polyphony. NIm seq is a NIm that includes sequential writing.

p: parallel imperfect intervals, either sixths (p6), thirds (p3), or tenths (p10).

par: chant paraphrase treatment of the tenor cantus firmus: notes added to the chant melody, and rhythmic values similar to those in the other voices.

PEn: set of Periodic Entries. This is a presentation type for imitative polyphony featuring entries of three or more voices after the same time interval of imitation. If the entries of the soggetto (tune treated in imitation) overlap, there is always a repeated module. "mod incl cad" (beginning of secunda pars) means that the module includes cadential voice leading.

Rests: the $\mathrm{T}$ is not sounding; indicates rests of more than a breve long.

S, A, T, B: Superius, Altus, Tenor, Bassus.

sf: stretto fuga. A type of imitation at a short time interval that is possible to improvise using rules of melodic interval choice. It can be for two voices ( $\mathrm{sf2} v$, a subset of FI-2) or 3 voices (sf3v, a subset of PEn). It is normally at the octave (not indicated in diagram), fifth, or fourth. One voice in a stretto fuga can sometimes be doubled in parallel thirds (thus mm. 46-51, sf2v TS w/p3).

$\mathbf{T}$ tr: tenor treatment.

Text: text in tenor part, according to underlay in Petrucci's Motetti C.

tri FI-2: triadic free imitation in two voices. When the tenor (and often another voice as well) has a long held note, two other voices are in imitation using only notes found in the appropriate triad, plus passing tones.

tri mel: triadic melody in one voice. 